Systematics, Environment, and Biogeography of Some Late Cambrian and Early Ordovician Trilobites From Eastern New York State

GEOLOGICAL SURVEY PROFESSIONAL PAPER 834

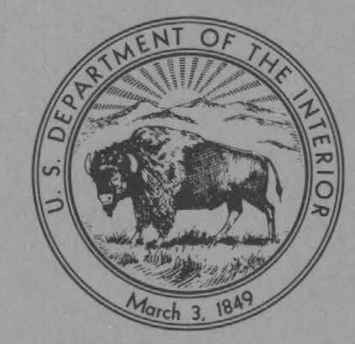



Systematics, Environment, and Biogeography

of Some Late Cambrian and

Early Ordovician Trilobites From

Eastern New York State

By MICHAEL E. TAYLOR and ROBERT B. HALLEY

GEOLOGICAL SURVEY PROFESSIONAL PAPER 834

The environmental setting and regional significance of two trilobite assemblages from shelf deposits of the

Whitehall Formation in the southern Champlain Valley

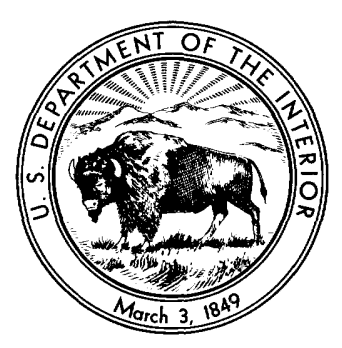

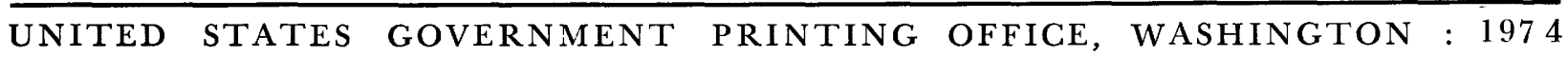




\section{UNITED STATES DEPARTMENT OF THE INTERIOR}

ROGERS C. B. MORTON, Secretary

\section{GEOLOGICAL SURVEY}

V. E. McKelvey, Director

Library of Congress catalog-card No. 73-600315

For sale by the Superintendent of Documents, U.S. Government Printing Office Washington, D.C. 20402 - Price $\$ 1.35$ (paper covers)

Stock Number 2401-02459 


\section{CONTENTS}

Introduction

Objectives

Geologic setting

Previous work

Acknowledgments

Biostratigraphy

Composition of Whitehall fauna

Trilobites

Gastropods --.--

Other fossils

Age and correlations

Problems and methods

Saukia Zone

Missisquoia Zone -..--

Symphysurina B Zone(?)

Cambrian-Ordovician boundary

Summary

Environmental setting

Petrology --.-----

Inferred environments

Biofacies distribution

Models

Methods of analysis

Assemblages dissimilar to Whitehall fauna
Abstract

Assemblages similar to Whitehall fauna

\begin{tabular}{|c|c|c|}
\hline Page & & Page \\
\hline 1 & Systematic paleontology & 18 \\
\hline 1 & Introductory statement & 18 \\
\hline 1 & Class Trilobita Walch, 1771 & 19 \\
\hline 1 & Family Catillicephalidae Raymond, 1938 ... & 19 \\
\hline 2 & Genus Acheilops Ulrich, 1931 & 19 \\
\hline 2 & Genus Stenochilina Ulrich, 1931 & 20 \\
\hline 2 & Family Heterocaryonidae Hupé, 1953 & 21 \\
\hline 4 & Genus Bowmania Walcott, 1925 & 21 \\
\hline 4 & Family Missisquoiidae Hupé, 1953 & 22 \\
\hline 4 & Genus Missisquoia Shaw, 1951 & 22 \\
\hline 4 & Family Plethopeltidae Raymond, 1925 & 23 \\
\hline 4 & Genus Plethometopus Ulrich, 1931 & 23 \\
\hline 4 & Genus Plethopeltis Raymond, 1913 & 25 \\
\hline $\begin{array}{l}4 \\
6\end{array}$ & $\begin{array}{c}\text { Family Ptychaspididae Raymond, } 1924 \\
\text { Subfamily Ptychaspidinae Longacre. }\end{array}$ & 26 \\
\hline 6 & 1970 & 26 \\
\hline $\begin{array}{l}8 \\
8\end{array}$ & Genus Euptychaspis Ulrich, $1931 \ldots$ & 26 \\
\hline $\begin{array}{l}0 \\
9\end{array}$ & Subfamily Saukiinae Ulrich and Resser, 1933 & 27 \\
\hline 9 & Genus Calvinella Walcott, 1914 & 27 \\
\hline 9 & Genus Prosaukia Ulrich and Resser, & \\
\hline 10 & 1933 & 28 \\
\hline 12 & Family Solenopleuridae Angelin, 1854 & 31 \\
\hline 12 & Genus Hystricurus Raymond, 1913 & 31 \\
\hline 13 & Description of fossil localities & 32 \\
\hline 13 & References cited & 33 \\
\hline 16 & Index ---------- & 37 \\
\hline
\end{tabular}

\section{ILLUSTRATIONS}

[Plates follow index]

Plate 1. Plethopeltis, Acheilops, Stenochilina, and Plethometopus.

2. "Calvinella," Euptychaspis, Boumania, and "Prosaukia."

3. Missisquoia and Hystricurus.

4. Photomicrographs of petrographic thin sections.

FIGURE 1. Geologic map showing fossil localities discussed in text

2. Columnar section showing typical repetition of components in limestones of the lower Whitehall Formation

3-5. Photograph showing-

3. Sharp vertical contact between crossbedded grainstone and finer grained clotted thrombolitic fabric

4. Domal stromatolites in the lower part of the Whitehall Formation

5. Domal thrombolite in the lower Whitehall Formation

6. Map showing the general location of principal areas of North America from which Saukia Zone faunas have been reported 


\section{TABLES}

TABLE 1. The occurrence of identified taxa in samples studied and the inferred biostratigraphic zonal assignment.-

2. Comparison of the biostratigraphic ranges of trilobite species and genera from the Whitehall Formation with occurrences in the central Great Basin, central Texas, and south-central Oklahoma

Page

5

3. Known occurrences of trilobite species recognized from the Saukia Zone at Whitehall, N.Y

4. Known North American occurrences of trilobite genera recognized from the Saukia Zone at Whitehall, N.Y 


\title{
SYSTEMATICS, ENVIRONMENT, AND BIOGEOGRAPHY OF' SOME LATE CAMBRIAN AND EARLY ORDOVICIAN TRILOBITES FROM EASTERN NEW YORK STATE
}

\author{
By Michael E. Taylor and Robert B. Halley ${ }^{1}$
}

\begin{abstract}
The Whitehall Formation in Washington County, eastern New York State, has yielded two assemblages of trilobites, gastropods, and other fossils, which are assigned to the Saukiella serotina Subzone of the Saukia Zone (Late Cambrian, Trempealeauan Stage) and to the Missisquoia Zone (Early Ordovician, Canadian Series). These occurrences support D. W. Fisher's interpretation that the CambrianOrdovician boundary, as currently recognized in North America, is within the Whitehall Formation.

The lower part of the Whitehall contains domal stromatolites, thrombolites, and lime grainstones interpreted to have formed in supratidal, intertidal, and shallow-subtidal marine environments. The vagile epibenthic fauna probably occupied warm-water, nearshore, shallow-subtidal habitats characterized by sustained moderate to high turbulence. Some limestone beds contain length-slow chalcedony which is thought to be an indicator of general hypersalinity or widely fluctuating salinity conditions in the environment of deposition.

Comparison of the Trempealeauan taxa from the Whitehall with other occurrences in North America suggests that the fauna is part of a shelf biofacies commonly occurring in areas of shallow-water carbonate deposition. The shelfcarbonate biofacies contrasts markedly with Trempealeauan trilobite assemblages that occupied sites of basinal sedimentation.

The Whitehall faunas studied contain 12 species of trilobites, 2 of which are indeterminate; at least 10 species of gastropods; Matthevia sp.; 2 species of Ribeiria, including Ribeiria cf. $R$. nuculitiformis Cleland, 1900; and 1 hyolithoid. Formal descriptions of trilobites are given. Seven trilobite species are assigned to previously named taxa, two are placed in open nomenclature, and "Prosaukia" spinula Taylor is new.
\end{abstract}

1 Department of Earth and Space Sciences, State University of New York, Stony Brook, NY 11790 .
INTRODUCTION

OBJECTIVES

Late Cambrian and Early Ordovician fossils from the Whitehall area of Washington County, eastern New York State, were studied to: (1) provide a more refined biostratigraphic classification of the Whitehall Formation than has been previously possible, (2) document the environmental setting of the Whitehall faunas, and (3) determine the biofacies relationship of the Whitehall Late Cambrian faunas relative to other known areas in North America.

Study of the sedimentary environments of the Whitehall Formation was begun by Halley as part of a graduate research project at Brown University (Halley, 1971a). During the course of his fieldwork, Halley collected fossils and made preliminary identifications of the trilobites. The fossils were later sent to Taylor in February 1971 for examination and proved similar to some currently being studied from the Great Basin (Taylor, 1971). In this report Taylor has taken responsibility for taxonomic, biostratigraphic, and biogeographic aspects and Halley, for stratigraphic occurrence, description, and environmental analysis of rocks of the Whitehall Formation.

\section{GEOLOGIC SETTING}

The Whitehall area of eastern New York State is in the southern Champlain Valley in a narrow belt of Cambrian-Ordovician miogeosynclinal carbonate 
and terrigenous clastic rocks which crop out between Precambrian rocks of the Adirondack Mountains to the west and the Cambrian-Ordovician Taconic sequence on the east (Theokritoff, 1964; Fisher, 1969). General geologic setting of the area is shown on the Adirondack Sheet of the Geologic Map of New York (Isachsen and Fisher, 1971), and the regional tectonic significance of the Whitehall area has been recently discussed by Rodgers (1970). The general location of the area studied and the geographic and geologic setting are shown in figure 1.

\section{PREVIOUS WORK}

The stratigraphy of the Whitehall area was described by Rodgers (1937). He named the Whitehall Formation for an easterly dipping sequence of interbedded sandstone, dolostone, and limestone cropping out on Skene Mountain at the east edge of the village of Whitehall, Washington County, N.Y. (fig. 1). The base of the formation is exposed on the west side of Skene Mountain about 120 feet below the crest (D. W. Fisher, written commun., 1972), and the top is exposed east of Skene Mountain (Rodgers, 1937 ) in the shallow valley occupied by Norton Road (Washington County Route 9A).

Wheeler (1942) formally recognized two members of the Whitehall Formation, a lower Hoyt Member and an upper Skene Member. Fisher (1956, 1968, 1969) summarized the stratigraphy and rock-nomenclatural history of the Whitehall area and is currently engaged in detailed stratigraphic studies of Cambrian and Ordovician rocks in the region (D. W. Fisher, written commun., 1971).

Cambrian fossils from the Whitehall area were described by Walcott (1912b) from possibly what are now termed the Potsdam and Ticonderoga Formations. The described fossils are older than those reported here. Wheeler $(1941,1942)$ was apparently the first to report Trempealeauan fossils from the Whitehall area, but his discoveries were never documented.

\section{FOSSIL COLLECTIONS}

Fossil collections used in this study came from three general sources. Robert B. Halley collected several fossil samples from the Whitehall Formation at Crossman quarry (H-1) and Warner Hill ( $\mathrm{H}-2$, $\mathrm{H}-3$ ), north of the village of Whitehall, N.Y., during 1970. The senior author spent several days during fall 1971 examining Whitehall Formation out- crops in the vicinity of Whitehall and collected two samples (7098-CO, 7099-CO) from the upper part of the type section at Skene Mountain (fig. 1).

Search of U.S. Geological Survey fossil collections in Washington, D.C., yielded several samples from the Whitehall area that proved relevant to this study. They include one sample collected by C. D. Walcott (418e), probably early in the 1900 's, and several collections made by E. O. Ulrich, Josiah Bridge, and Rudolph Ruedemann in 1931 (470b, $\left.470 \mathrm{~b}_{1}, 473 \mathrm{f}\right)$. The general geographic and geologic setting of the samples is shown in figure 1. Detailed locality information is given on page 32 .

Trilobites illustrated in this report are in the collections of the Department of Paleobiology, U.S. Museum of Natural History (USNM), Washington, D.C. Silicon rubber positive replicas of the illustrated specimens and representative nonillustrated material have been deposited in the New York State Museum, Albany, N.Y. All other nonillustrated material is in the trilobite collections of the U.S. Geological Survey, Washington, D.C.

\section{ACKNOWLEDGMENTS}

The authors especially wish to thank Donald W. Fisher for making available unpublished data on the Cambrian-Ordovician rocks and fossils of the Whitehall area and for his generosity in allowing us to publish a geologic index map prepared from his unpublished field data. Ellis L. Yochelson is thanked for providing gastropod identifications and John Pojeta, Jr., for identifying Ribeiria nuculitiformis Cleland. John H. Shergold originally pointed out the general similarity between Missisquoia and Parakoldinioidia. Taylor wishes to thank A. J. Rowell for several stimulating discussions on Late Cambrian biogeography.

Halley thanks Conrad D. Gebelein, Donald W. Fisher, and A. R. Palmer for guidance in the field and Leo F. Laporte who supervised thesis research which led, in part, to the present report. The New York Geological Survey provided field funds to Halley during 1970.

Persons to whom we are grateful for reading various versions of the manuscript and offering useful suggestions include: A. K. Armstrong, D. W. Fisher, J. F. Mello, A. R. Palmer, R. A. Robison, R. J. Ross, Jr., J. H. Shergold, J. H. Stitt, and E. L. Yochelson. 


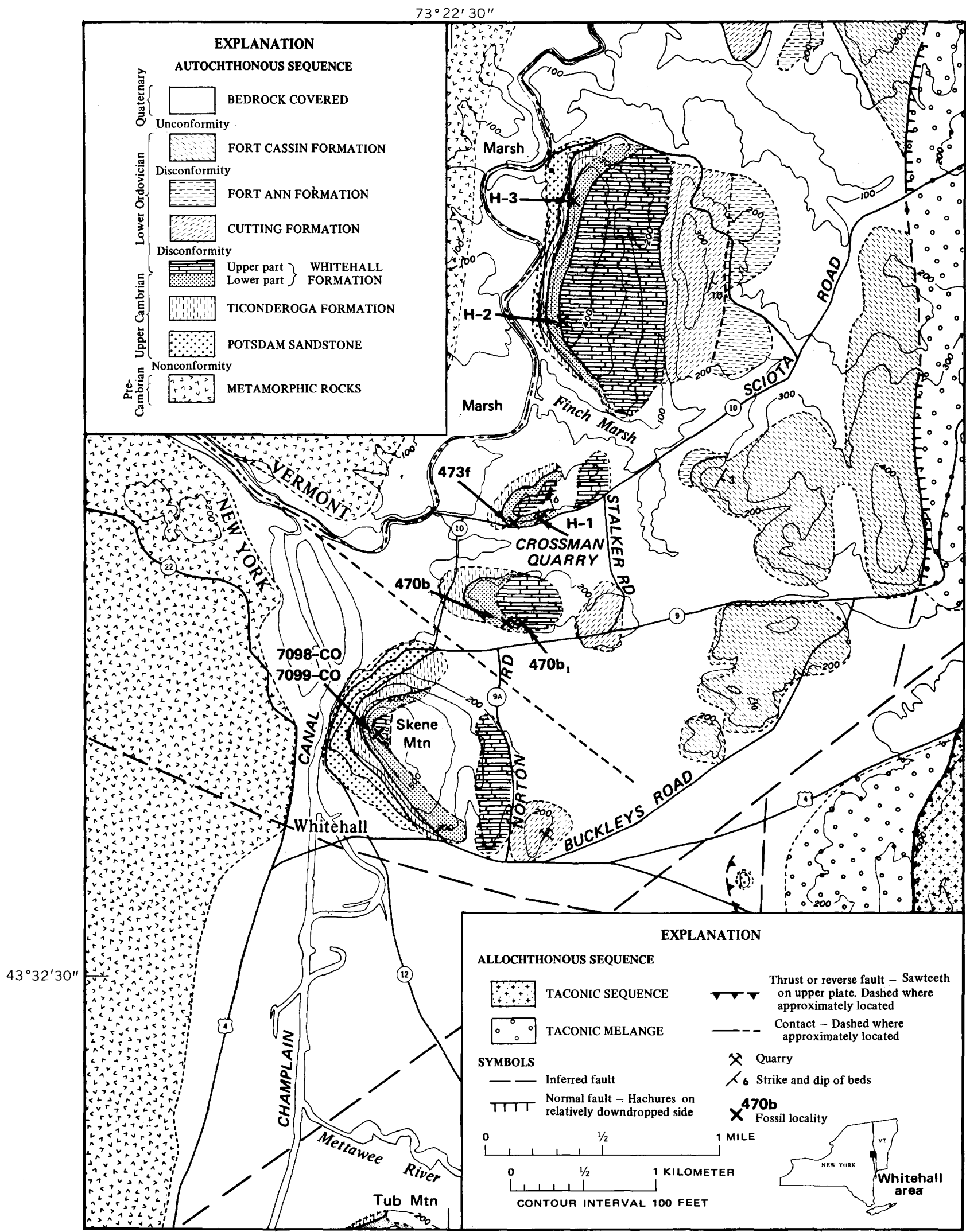

Figure 1.-Geologic map showing fossil localities discussed in text. Detailed locality description are given on pages 32 and 33. Geology is generalized from unpublished geologic maps made available through the courtesy of D. W. Fisher, New York State Museum and Science Service, Albany, N.Y. Base from Whitehall and Thorn Hill, New York-Vermont 71/2-minute quadrangles. 


\section{BIOSTRATIGRAPHY}

\section{COMPOSITION OF WHITEHALL FAUNA}

The fauna here reported from the Whitehall Formation consists of 12 species of trilobites, two of which are indeterminate, at least 10 species of gastropods, fragmentary material referred to the problematical mollusk Matthevia, one indeterminate hyolithoid, and several bivalved fossils assigned to Ribeiria sp. and Ribeiria cf. R. nuculitiformis Cleland. Formal systematic descriptions are given for the trilobites. All taxa recognized are listed in table 1 except those from locality $418 \mathrm{e}$, which is discussed below.

\section{TRILOBITES}

Fossil sample H-3 from the Whitehall Formation on the north end of Warner Hill contains the most diverse trilobite assemblage of those samples studied. The sample contains Acheilops masonensis Winston and Nicholls, "Calvinella" prethoparia Longacre, Euptychaspis typicalis Ulrich, Plethopeltis sp. indet., and "Prosaukia" spinula Taylor, n. sp. Sample $\mathrm{H}-1$ from Crossman quarry is similar in taxonomic composition but lacks Plethopeltis and Acheilops masonensis and includes Bowmania cf. B. pennsylvanica Rasetti. Sample 473f, probably collected near Crossman quarry, contains Euptychaspis typicalis, Plethometopus obtusus Rasetti, Plethometopus sp. A, and cf. "Prosaukia" spinula. Locality 470b, from the low hill between Skene Mountain and Crossman quarry, contains Acheilops masonensis, Euptychaspis sp. indet., and "Prosaukia" spinula.

Inspection of table 1 shows that samples $\mathrm{H}-3$, $\mathrm{H}-1,473 \mathrm{f}$, and $470 \mathrm{~b}$ are similar in taxonomic composition but are not identical. The geographic proximity and taxonomic overlap suggests that differences between localities may reflect only sampling differences at approximately the same biostratigraphic horizon. Alternatively, the differences in taxonomic composition could reflect differences in species range in the local stratigraphic sequence or local environment $a l$ factors. The latter alternatives cannot be ruled out at present.

Sample 418e, from northeast of Whitehall (exact locality unknown), contains Stenochilina sp. A, in association with the gastropods ?Schizopea sp. and Dirachopea sp. Stenochilina was not found in any other Whitehall samples, so its occurrence relative to other samples cannot be inferred at present.
Sample $470 b_{1}$ from the hill between Skene Mountain and Crossman quarry and samples 7098-CO and 7099-CO from Skene Mountain contain Missisquoia typicalis Shaw. These samples all contain abundant and abraded trilobite debris, but $M$. typicalis is the only trilobite taxon recognized.

Sample H-2 from the southwest side of Warner Hill contains Hystricurus millardensis Hintze and three specimens questionably assigned to Missisquoia typicalis Shaw. Hystricurus was not recognized in any other Whitehall samples studied.

\section{GASTROPODS}

Gastropods were not studied in detail. However, identifications kindly provided by E. L. Yochelson (written commun., Dec. 1971 and Oct. 1972) and data on associations are given in table 1 .

\section{OTHER FOSSILS}

Hyolithoids occur rarely in sample $\mathrm{H}-3$, and fragmentary material attributed to Matthevia occurs in sample $470 \mathrm{~b}$. Several bivalved fossils attributed to Ribeiria sp. occur in sample 470b, and John Pojeta, Jr. (oral commun., 1972), identified Ribeiria cf. $R$. nuculitiformis Cleland from sample 7098-CO. These fossils were not studied in detail.

\section{AGE AND CORRELATIONS}

\section{PROBLEMS AND METHODS}

Biostratigraphic studies in the Upper Cambrian and Lower Ordovician of Washington County, N.Y., are complicated by discontinuous outcrops resulting from faulting and by vegetation and soil cover. As a result, it is commonly necessary to study fossils from isolated exposures or single horizons which are difficult to relate to one another. This general problem has been compounded in rocks of latest Cambrian age (Trempealeauan Stage) by the general lack of a practicable biostratigraphic scale for subdividing the sequence. Trilobite zonal schemes for the type area of the Late Cambrian Trempealeauan Stage in the Upper Mississippi Valley (Howell and others, 1944; Raasch, 1951; also see Nelson, 1953) have not been successfully applied to other regions because of lack of systematic treatment of much of the fauna and perhaps because of biofacies differences.

In recent years, research in highly fossiliferous sections of latest Cambrian (Trempealeauan Stage) and earliest Ordovician carbonate rocks outside the 
TABLE 1.-The occurrence of identified taxa in samples studied and the inferred biostratigraphic zonal assignment

[The stratigraphic sequence of samples is inferred from an interpretation of trilobite species associations compared with occurrences in other areas (see text). Explanation of symbols: $\times$, established occurrence, identification definite; cf., established occurrence, identification tentative; ?, esta-
blished occurrence, identification questionable. Moldusks were identified by Ellis L. Yochelson (written commun., December 1971, October 1972]

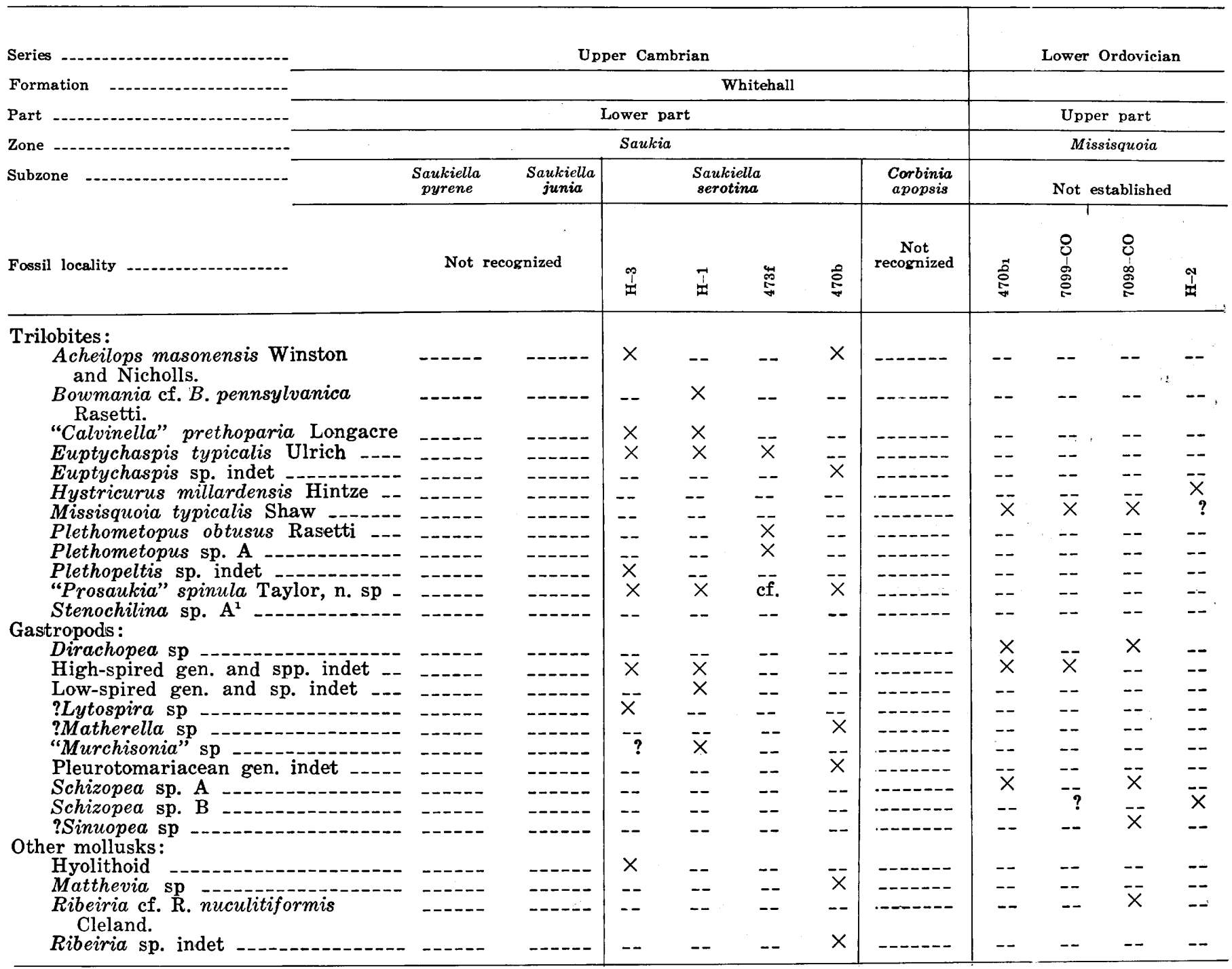

${ }^{1}$ Occurs in sample $418 \mathrm{e}$, see text.

Upper Mississippi Valley region has focused on the problem of developing a regionally practicable biostratigraphic scheme for correlation. This research, largely a result of the efforts of Prof. W. Charles Bell and his students, has resulted in a fourfold biostratigraphic subdivision of the Trempealeauan (=Saukia Zone) based on local ranges and associations of trilobite species in the Wilberns Formation of central Texas (Bell and Ellinwood, 1962; Winston and Nicholls, 1967). Longacre (1970) refined and provided additional information on the Texas fossil sequence, and Stitt (1971) established a similar zonal scheme for the limestones of the Fort Sill and Signal Mountain Formations of south-central Oklahoma. Independent concurrent work by Taylor
(1971) showed that a similar fourfold subdivision of the Saukia Zone can be recognized in the eastcentral Great Basin, and Derby and others (1972) have recognized some of the subzones in southern Alberta, Canada.

The Whitehall faunas show a strong biogeographic similarity to faunas from Oklahoma, Texas, and the Great Basin (discussed under "Biofacies Distribution)." As a consequence, it is possible to infer a subzonal assignment for the Whitehall samples by comparing taxonomic associations with relative ranges of the same taxa in known sequences. The relative ranges of Whitehall species that also occur in the Great Basin, central Texas, and south-central Oklahoma, are given in table 2 as are the ranges of 
genera common to the three regions.

\section{SAUKIA ZONE}

Relative ranges of species within the Saukia Zone as recognized in the Great Basin, central Texas, and south-central Oklahoma, provide a basis for inferring the age of the Whitehall trilobites. Inspection of table 2 shows that relative ranges of most taxa overlap in the Saukiella serotina Subzone of the Saukia Zone. The comparison is strongest with sample $\mathrm{H}-3$ from Warner Hill. Samples $\mathrm{H}-3$ and $\mathrm{H}-1$ could be assigned to the Saukiella junia Subzone, but this alternative seems less likely because of the occurrence of "Calvinella" prethoparia, a species apparently restricted to the Saukiella serotina Subzone.

Inspection of the relative ranges of genera (table 2) shows that most are too long ranging to be of value in subdividing the Saukia Zone. "Calvinella" may be an exception, as its known occurrence is restricted to the Saukiella serotina Subzone in these areas. However, this apparent restriction is probably a reflection of the occurrence of a group of forms similar to "C." prethoparia in the three areas. Calvinella $s$. $l$. is a very broadly circumscribed genus which needs comprehensive reevaluation before emphasis can be placed on the occurrence of the genus alone. (See further discussion under "Systematic Descriptions.")

Sample 418e contains Stenochilina, a genus of catillicephalid trilobite that occurs in association with Saukia Zone faunas reported from the Conococheague Limestone of Maryland (Rasetti, 1959, p. 383) and the Eminence Dolomite of southeastern Missouri (Ulrich, 1930, p. 215). These occurrences establish the Trempealeauan age of the sample, but data are insufficient to assign it to a subzone.

Saukia Zone trilobites have been described and illustrated by Walcott $(1879,1912 \mathrm{~b})$ from the Hoyt Limestone near Saratoga Springs, N.Y. Some additional Late Cambrian fossils from the Saratoga Springs area were illustrated by Rasetti (1946) and by Fisher and Hanson (1951). Our Late Cambrian collections from the Whitehall Formation were compared with the material in the U.S. National Museum collections studied by Walcott $(1912 b)$. The examination showed that available collections from the two areas contain no trilobite species in common. The mollusks reported by Walcott (1912b) from the Hoyt include species of Triblidium, Matherella,
Matthevia, and Pelagiella. Of these molluscan taxa, only Matthevia and one specimen questionably assigned to Matherella were recognized in the Whitehall samples studied.

The Hoyt fauna from Saratoga County, N.Y., contains trilobite forms that do not occur in the described faunas from Oklahoma, Texas, or the Great Basin. As a result, it is not now possible to assign the Hoyt fauna to any of the subzones of the Saukia Zone. Therefore, although faunas from the Hoyt Limestone and lower Whitehall Formation can be assigned to the Trempealeauan Stage, it is not yet possible to document on paleontological evidence which parts of these two formations are synchronous.

Lochman (1946) described and illustrated Prosaukia briarcliffensis and Plethometopus knopf from the Briarcliff Dolomite near Pine Plains in Dutchess County, N.Y. The fauna can be assigned to the Saukia Zone, but further refinement in classification cannot be made at present.

Dwight $(1886 a, b ; 1887)$ reported a rich collection of trilobites from outcrops near Poughkeepsie, Dutchess County, N.Y., which he (1887, p. 208) correlated with the Hoyt fauna at Saratoga Springs (then called "Potsdam limestone"). Apparently the Poughkeepsie fauna has been neither described nor illustrated so that further comparison cannot be made at present.

Bird and Rasetti (1968) listed several occurrences of probable Trempealeauan fossils from the Taconic sequence of Columbia County, eastern New York State. Examination of the material showed that the collections contain no genera or species in common with the Whitehall fauna. The Taconic localities contain genera typical of the Hungaia magnifica fauna (Bird and Rasetti, 1968, p. 45), but the full significance of the occurrences must await formal description of the fossils.

\section{MISSISQUOIA ZONE}

Sample $470 b_{1}$, from the low hill between Skene Mountain and Crossman quarry, samples 7098-CO and 7099-CO from the upper part of the Whitehall Formation on Skene Mountain, and questionably sample H-2 from Warner Hill, contain Missisquoia typicalis Shaw in association with abundant gastropods. (See table 1.) Missisquoia typicalis was originally described from the Highgate Formation of northwestern Vermont (Shaw, 1951, 1955, 1958). Subsequently, the species was reported from the 
TABLE 2.-Comparison of the biostratigraphic ranges of trilobite species and genera from the Whitehall Formation with occurrences in the central Great Basin, central Texas, and south-central Oklahoma

[No attempt has been made to depict differences between regions in local range within Cambrian subzones or Early Ordovician zones] Explanation of symbols: $\oplus$ Great Basin (Hintze, 1952; Taylor 1971.

$\star$ Central Texas (Winston and Nicholls, 1967; Longacre, 1970).

South-central Oklahoma (Stitt, 1971).

Epoch -...-

Subzone

\begin{tabular}{cc|c} 
Late Cambrian & Early Ordovician \\
\hline Saukia & Missisquoia $\begin{array}{c}\text { Symphy- } \\
\text { surina B }\end{array}$ \\
\hline $\begin{array}{c}\text { Saukiella } \\
\text { pyrene }\end{array} \quad \begin{array}{c}\text { Saukiella } \\
\text { junia } \quad \begin{array}{c}\text { Saukiella } \\
\text { serotina }\end{array} \quad \begin{array}{c}\text { Corbinia } \\
\text { apopsis }\end{array}\end{array}$ & Not established \\
\hline
\end{tabular}

Species :

Acheilops masonensis Winston and Nicholls

Aowman pennsyluanica Rasetti $-10-0$

Bowmania pennsylvanica Rasetti

"Calvinella" prethoparia Longacre

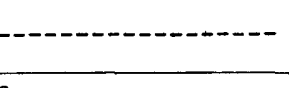

Euptychaspis typicalis Ulrich

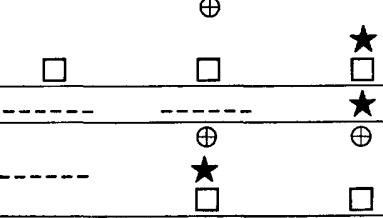

Hystricurus millardensis Hintze

\begin{tabular}{|c|c|c|c|c|c|c|}
\hline 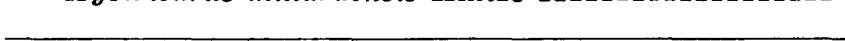 & & & & & & $\underline{\square}$ \\
\hline Missisquoia typicalis Shaw & ---- & ---- & ---- & ----- & $\stackrel{\bullet}{\star}$ & --- \\
\hline Plethometopus obtusus Rasetti & ----- & ---- & 苔 & $\stackrel{\hbar}{\square}$ & ----- & $\cdots-\cdots$ \\
\hline Plethometopus sp. A & $\ldots-\cdots$ & ----- & $\ldots-\ldots$ & ---- & ----- & 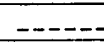 \\
\hline 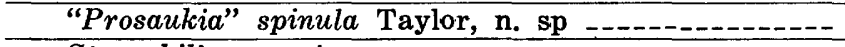 & $\ldots-\cdots$ & ----- & $-\cdots--$ & $-\cdots--$ & $-\cdots-\cdots$ & $-\cdots$ \\
\hline Stenochilina sp. A & $-\cdots$ & $-\cdots--$ & $-\ldots$ & $-\ldots$ & $\ldots-\cdots$ & $\ldots$ \\
\hline Genera: & $\oplus$ & $\oplus$ & & $\oplus$ & & \\
\hline Acheilops Ulrich & & & $\stackrel{\star}{\square}$ & $\star$ & ---- & \\
\hline Bowmania Walcott & $\begin{array}{l}\text { ? } \\
\square\end{array}$ & $\begin{array}{l}\oplus \\
\square\end{array}$ & $\begin{array}{l}\bar{\theta} \\
\star \\
\stackrel{\square}{ }\end{array}$ & $\square$ & -- & \\
\hline “Calvinella" Walcott _- & & & $\begin{array}{l}\oplus \\
\star \\
\square\end{array}$ & $--\cdots$ & - & \\
\hline Euptychaspis Ulrich & $\stackrel{\oplus}{\star}$ & $\begin{array}{l}\oplus \\
\star \\
\square\end{array}$ & $\begin{array}{l}\oplus \\
\star \\
\dot{\square}\end{array}$ & ------ & -- & \\
\hline Hystricurus Raymond (-..- & - & - & ----- & - & $\stackrel{\oplus}{\star}$ & $\begin{array}{l}\oplus \\
\star \\
\stackrel{\square}{ }\end{array}$ \\
\hline Missisquoia Shaw & ----- & ---.-- & ----- & ---- & $\begin{array}{l}\oplus \\
\star \\
\square\end{array}$ & \\
\hline Plethometopus Ulrich & $\begin{array}{l}\text { ? } \\
\star \\
\stackrel{n}{\square}\end{array}$ & $\stackrel{\oplus}{\star}$ & $\begin{array}{l}\oplus \\
\star \\
\square\end{array}$ & $\hat{\square}$ & ---- & -- \\
\hline Plethopeltis Raymond - & $\star$ & $-\cdots--$ & $\oplus$ & $\oplus$ & $\square$ & --- \\
\hline "Prosaukia" Ulrich and Resser & $\oplus$ & $-\cdots--$ & $\stackrel{\square}{\square}$ & ----- & ----- & \\
\hline Stenochilina Ulrich & ----- & ------ & ----- & ----- & ----- & --- \\
\hline
\end{tabular}

${ }^{1}$ Also reported in pre-Saukiella pyrene beds.

Wilberns Formation of central Texas (Winston and Nicholls, 1967). Winston and Nicholls (p. 72) showed that part of the Wilberns Formation contains an assemblage of trilobites consisting of species of Homagnostus, Hystricurus, Symphysurina, Highgatella, Missisquoia, and Parabolinella. The association, named the Missisquoia Zone, occurs stratigraphically between faunas characteristic of the

subjacent Corbinia apopsis Subzone of the Saukia Zone and a superjacent zone consisting of an association of species of Clelandia, Hystricurus, Jujuyaspis, Homagnostus, and Symphysurina. Winston and Nicholls (1967) considered the latter association most similar to the Symphysurina B Zone of Ross (1951) and Hintze (1952).

Norford (1969) reviewed the known distribution 
of some Early Ordovician trilobites in North America and concluded that the Missisquoia and Symphysurina Zones of Winston and Nicholls (1967) together probably represent Zone A of Ross (1951). Evidence for this interpretation is the reported occurrence of Hystricurus cf. $H$. sp. D of Ross in both the Missisquoia and Symphysurina zones of Winston and Nicholls. Hystricurus sp. D of Ross is otherwise known from Zone A of Ross (1951, p. 29) near the base of the Garden City Formation in southeastern Idaho. This evidence is considered tenuous, and we prefer to recognize the Missisquoia Zone as originally defined by Winston and Nicholls (1967).

Stitt (1971) studied the biostratigraphy of Late Cambrian and Early Ordovician trilobites in the western Arbuckle Mountains of south-central Oklahoma. He reported a trilobite association that includes species of Hystricurus, Symphysurina, Missisquoia (including $M$. typicalis), Apoplanias, Homagnostus, and Plethopeltis, which he assigned to the Missisquoia Zone. The Missisquoia Zone assemblage occurs in the Signal Mountain Limestone where it is underlain by assemblages assigned to the Corbinia apopsis Subzone. Beds immediately above the Missisquoia Zone are only sparsely fossiliferous, so that the top of the zone is poorly defined in Oklahoma.

The Missisquoia Zone also occurs in the uppermost part of the Notch Peak Limestone in the southern House Range of west-central Utah (Taylor, unpub. data, 1971). The Notch Peak contains an association of species of Highgatella, Hystricurus, Missisquoia (including $M$. typicalis), and Symphysurina, which overlies Corbinia apopsis Subzone assemblages. The Notch Peak Limestone is conformably overlain by the House Limestone, in the lower part of which Hintze (1952) originally established the presence of the Symphysurina B Zone in western Utah.

Derby, Lane, and Norford (1972) reported a Missisquoia Zone fauna from the Survey Peak Formation in the southern Rocky Mountains of Alberta. The listed fauna contains species of Apoplanias, Missisquoia (tentatively referred to $M$. typicalis), Highgatella, and a large number of nontrilobite taxa. Derby, Lane, and Norford (1972) redefined the Missisquoia Zone to coincide with the biostratigraphic interval between the first occurrence of Apoplanias and the first occurrence of Symphysurina in the Survey Peak Formation. The regional practicability of this redefinition remains to be proved because: (1) species of Symphysurina seem to occur earlier in central Texas and south-central Oklahoma in association with Missisquoia typicalis, and (2) Lochman and Wilson $(1967$, p. 893) reported that an undescribed species of Apoplanias may be present in association with Saukia Zone assemblages in central Montana.

In summary, the known biostratigraphic occurrences of Missisquoia typicalis are restricted to the Missisquoia Zone as originally defined in North America. The upper Whitehall occurrences are tentatively assigned to the zone on this basis.

\section{SYMPHYSURINA B ZONE(?)}

Sample H-2 from the upper part of the Whitehall Formation at Warner Hill contains Hystricurus millardensis Hintze, Missisquoia typicalis Shaw(?), and several poorly preserved gastropods. Hystricurus millardensis was originally reported from the Symphysurina B Zone in the southern House Range area of west-central Utah (Hintze, 1952). Subsequently, the species was recognized in the Symphysurina Zone of central Texas (Winston and Nicholls, 1967) and south-central Oklahoma (Stitt, 1971). This apparent restriction of $H$. millardensis to the Symphysurina B Zone provides limited evidence for inferred presence of the zone in the upper part of the Whitehall Formation. Alternatively, the absence of Symphysurina and presence of Missisquoia typicalis (?) in sample H-2 is suggestive of the Missisquoia Zone. Sample H-2 is tentatively assigned to the Missisquoia Zone for this reason, although further collecting at Warner Hill is necessary to verify the zonal assignment.

\section{CAMBRIAN-ORDOVICIAN BOUNDARY}

The base of the Ordovician System in North America has been traditionally recognized by the lowest occurrence of Symphysurina (Ross, 1951; Hintze, 1952; Bell and others, 1956; Palmer, 1971a; Lochman, 1971), even though the position of the boundary probably differs from that in the classic areas of Europe (Whittington and Williams, 1964; Whittington, 1966). The Missisquoia Zone contains the earliest known occurrence of Symphysurina in North America (Winston and Nicholls, 1967; Stitt, 1971; Taylor, 1971), although not at the base (Derby and others, 1972), and is therefore tentatively accepted here as the earliest trilobite assemblage zone of the Ordovician System in North America. As so recognized, the Cambrian-Ordovician boundary falls within the Whitehall Formation in Washington 
County, N.Y. (Fisher, 1968, 1969), rather than at the base (Rodgers, 1937; Fisher, 1962) or top (Wheeler, 1942; Flower, 1964) of the formation, as had previously been thought. Available biostratigraphic data are not sufficiently refined at present to determine how closely the boundary between lower and upper parts of the formation approximates the systemic boundary.

\section{SUMMARY}

The age of fossil samples from the Whitehall Formation in eastern New York is inferred from the known range of species in biostratigraphic sequences in other areas. On this basis, samples can be grouped into two taxonomic assemblages. The older assemblage from the lower part of the Whitehall is assigned to the Saukiella serotina Subzone of the Late Cambrian Saukia Zone, and the younger assemblage from the upper part of the Whitehall is assigned to the earliest Ordovician Missisquoia Zone. The Corbinia apopsis Subzone, which normally occurs between the Saukiella serotina Subzone and Missisquoia Zone, has not yet been recognized in New York State. Biostratigraphic classification of the Whitehall fossil samples is shown in table 1.

\section{ENVIRONMENTAL SETTING}

Fossils described in this paper were collected from limestones within the Whitehall Formation or from loose blocks presumed to be derived from the Whitehall. The fossils mostly occur as poorly sorted bioclastic debris in beds composed of ooid-skeletal lime grainstone. All fossils studied represent vagile epibenthos that were presumably highly susceptible to post-mortem transport and mixing that could potentially obscure original natural spatial relationships between organisms and environments. The fragmented condition of most trilobite exuviae is usually evidence that some mechanical degradation occurred before burial. However, the very poor sorting and common association of a wide variety of grain shapes with presumably different hydrodynamic properties suggests that distances of post-mortem transport were probably short, perhaps on the order of tens of feet rather than thousands of feet or miles. This conclusion is consistent with the findings of Ginsberg (1956), who showed that the bulk of skeletal carbonate grains in the Florida reef tract coarser than one-eight of a millimeter accumulate in the subenvironment in which the grains originate. The fact that taxonomic associations similar to those in the Whitehall can be recognized in widely scattered parts of North America (see "Biofacies Distribution") adds credence to the interpretation that fossils were not transported great distances before burial. (Also see Mudge and Yochelson, 1962, p. 108.) Such recurrent associations of vagile epibenthic taxa may be considered parautochthonous faunules. However, the inferred correlation between a particular faunule and a particular environment should be accepted only cautiously because of the possibility that bioclastic debris accumulated near, but not necessarily in, the precise microenvironment occupied by the living organisms.

In spite of the tenebrous influence of biostratinomic factors, the fossil-enclosing rocks are thought to contain the best independent evidence currently available for deducing the physical environment occupied by the fossils. Comparisons can be made between observed depositional features of the Whitehall and those of recent and other ancient carbonate sediments and rocks to provide a basis for inferences concerning some aspects of the environment in which the Whitehall organisms lived. Thus, here we review those aspects of the limestones, based on Halley's (1971a) detailed study, which might have particular relevance to the environmental setting of the Whitehall fauna, rather than present a detailed petrographic description of the Whitehall Formation.

\section{PETROLOGY}

The bulk of the limestones examined from the Whitehall consist of grainstones and boundstones (in the carbonate rock classification of Dunham, 1962). These are the predominant lithologies of the exposures at Crossman quarry (fig. 2), the upper slopes of Warner Hill, Skene Mountain, and Tub Mountain. (See fig. 1.) Constituent particles of the grainstones in order of decreasing abundance are ooids, lithoclasts, pelletoidal grains, quartz grains, and trilobite and gastropod fragments. (See pl. 4.) Chert, length-slow chalcedony, pyrite, dolomite, and chlorite are minor (less than 1 percent) diagenetic minerals present. The Whitehall grainstones occur as individual beds or as fill between boundstone structures (fig. 3). Beds composed entirely of grainstone are 2-24 inches thick, uniform in thickness for the length of outcrop (as much as 100 yards), and often have either low-angle crossbedding or planar bedding.

Boundstones of the Whitehall Formation are thought to be cryptalgal structures (Aitken, 1967; Halley, 1971b) formed by the sediment-binding and 


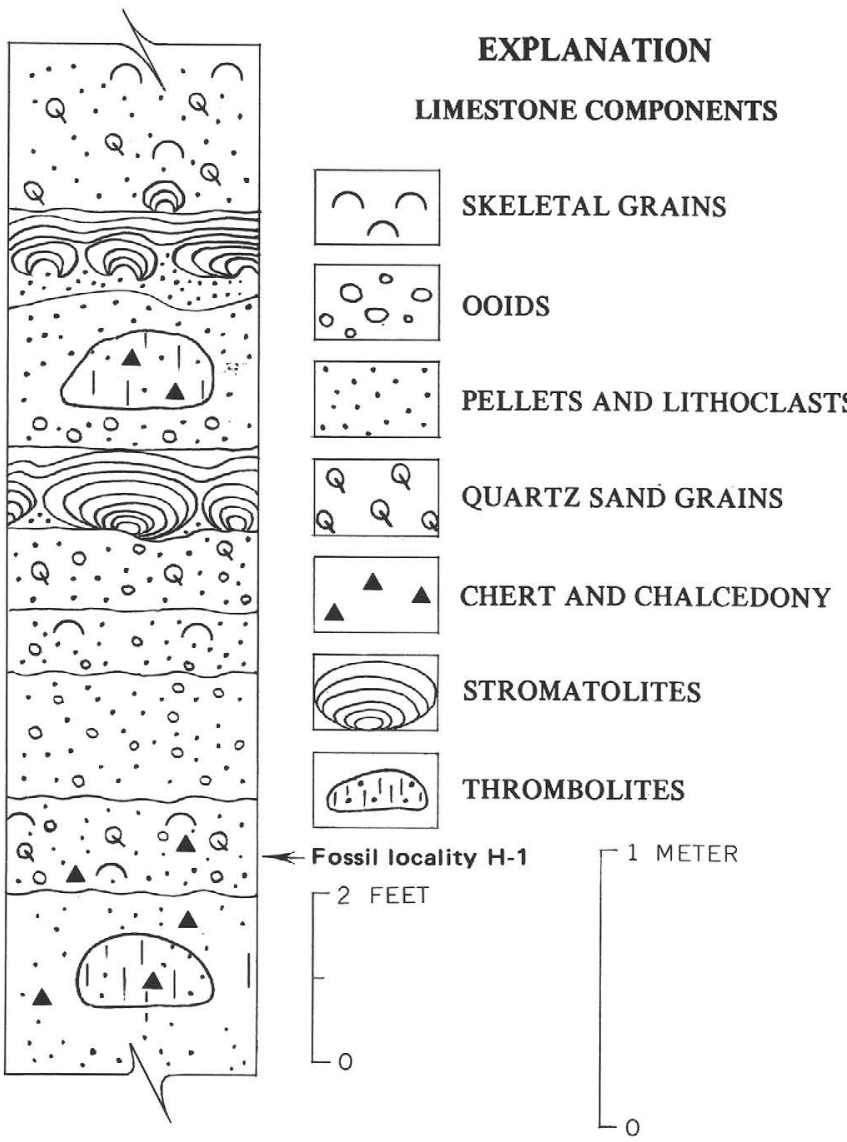

FIGURE 2.-Columnar section showing typical repetition of components in limestones of the lower Whitehall Formation, exposed on the east side of Crossman quarry 8-20 feet above the quarry floor. Photomicrographs of thin sections showing the various lithic types are given on plate 4, figures 1-6.

(or) carbonate-precipitating activities of nonskeletal algae. Domal stromatolites are cryptalgal structures characterized by convex-upward laminations. Layers within the Whitehall domal stromatolites have a clastic texture, and the laminated fabric is produced by variations in grain size (pl. 4, fig. 6). Relief of Whitehall stromatolites ranges from 0 to 18 inches, as evidenced by tracing single laminations around the structures (fig. 4).

Two distinctly different types of nonlaminated cryptalgal structures (thrombolites of Aitken, 1967) occur in the Whitehall. The most common type forms both beds and individual mound structures with as much as 12 inches of surface relief (fig. 5). Fabric observed in outcrop appears clotted whereas in thin section the texture is clastic with clots formed by variations in grain packing. Clots that appear light gray in outcrop are grain supported; darker clots are spar rich and are not grain supported (pl. 4, fig. 5). The second type of nonlaminated cryptalgal structure consists of lime mudstone mounds without clastic textures. These structures are less common and also have clotted fabric. However, the light-gray clots in mudstone mounds are internally grain-filled fenestrae as much as 1 inch long in the largest dimension. Some fenestrae have spar-filled geopetal surfaces (pl. 4, fig. 4). The matrix of nonlaminated mounds is finely crystalline to aphanocrystalline, dark gray to black, the finer grained patches being darker in color value. Individual grains are rarely recognized in lime mudstone mounds outside of the grain-filled fenestrae.

The Whitehall grainstones and three types of boundstones recur vertically in beds a few inches to several feet thick (fig. 2). This phenomenon was interpreted (Halley, 1971a) to have been produced by oscillations of the strandline.

\section{INFERRED ENVIRONMENTS}

The depositional environments of the Whitehall Formation may be inferred from comparisons with recent and ancient carbonate deposits. Domal highrelief stromatolites have been reported forming today in the intertidal zone of Hamelin Pool, a hypersaline lagoon in Shark Bay, Western Australia (Logan, 1961; Logan and others, 1964; Davies, 1970). Surface relief of the Shark Bay algal stromatolites has been correlated with water turbulance. High-relief forms are typical in the low intertidal zone of exposed headlands, whereas low-relief forms

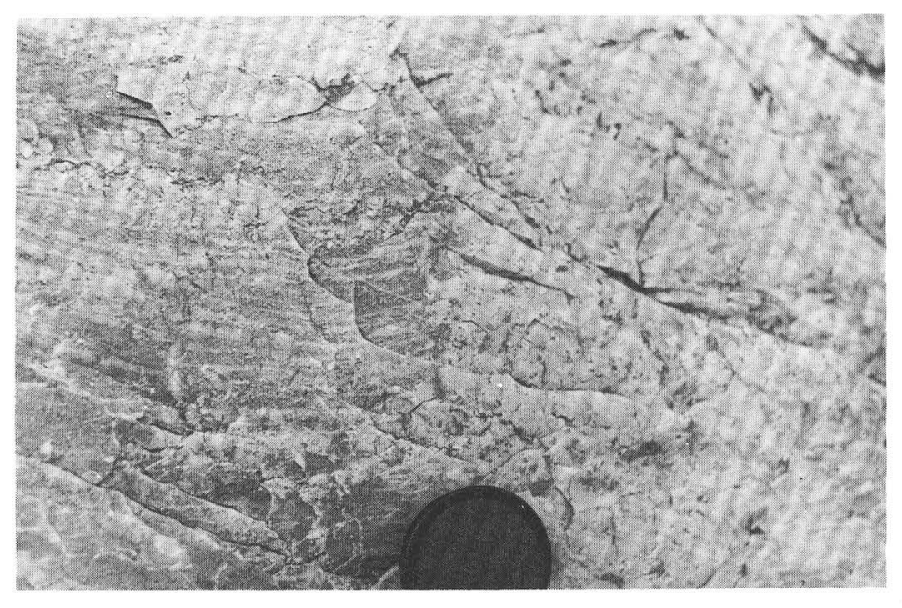

FiguRE 3.- Sharp vertical contact between low-angle crossbedded grainstone to the left, and finer grained clotted thrombolitic fabric to the right. Lower Whitehall Formation, Crossman quarry. Lens cap is 3 inches $(7.5 \mathrm{~cm})$ in diameter. 


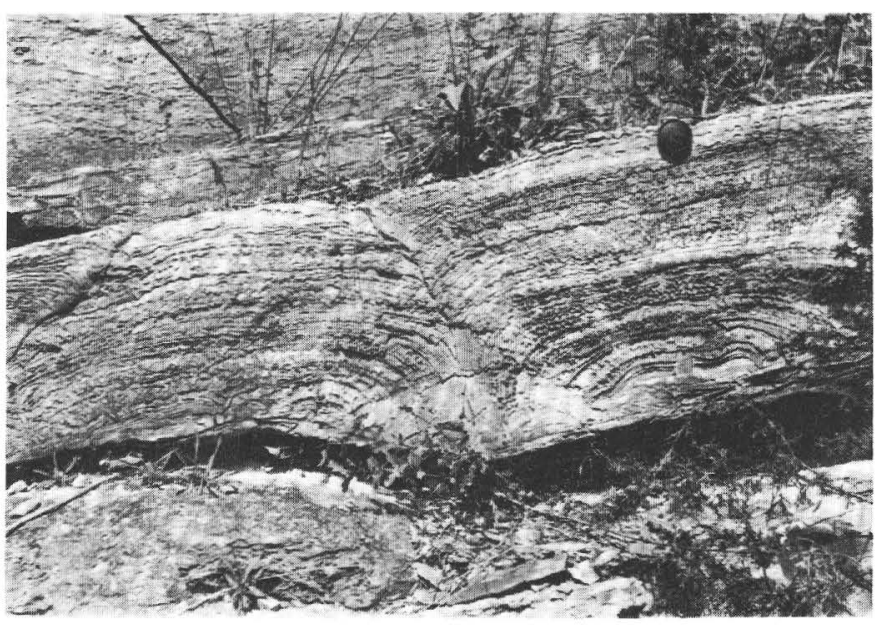

Figure 4.-Domal stromatolites in the lower part of the Whitehall Formation, Crossman quarry. Relief on these particular forms decreases upward so that the upper few inches are nearly flat laminated. Lens cap is 3 inches $(7.5 \mathrm{~cm})$ in diameter.

and flat-laminated sediments (incipient cryptalgalaminates) occur in high-intertidal and supratidal sites and on tidal flats along protected shorelines (Logan, 1961, p. 529; Hoffman and others, 1969; Davies, 1970 , p. 181). Low-relief stromatolites and flat-laminated sediments also characterize the high intertidal zone of south Florida (Ginsburg and others, 1954; Gebelein and Hoffman, 1969); Andros Island, Bahamas (Shinn and others, 1969, p. 12111216); and the Abu Dhabi along the Persian Gulf (Kendall and Skipwith, 1968). These features, when recognized in ancient rocks, can be used to infer near-sea-level or tidal-flat deposition. Many modern studies have successfully applied these modern analogues to the interpretation of ancient carbonate environments (for example, Roehl, 1967; Laporte, 1967). By analogy with recent patterns of occurrence, stromatolites and cryptalgalaminates in the lower part of the Whitehall Formation are inferred to have formed under conditions of tidal-flat deposition.

Recent carbonate fabrics analogous to thrombolites have not been reported. However, Aitken (1967, p. 1176) inferred from studies in Cambrian and Ordovician rocks of Alberta that thrombolites may have formed in low intertidal and shallow subtidal sites, possibly under hypersaline conditions.

Low-angle and planar crossbedded carbonate sands are characteristically found in low intertidal and shallow subtidal sites in the Bahamas (Imbrie and Buchanan, 1965). In the Whitehall, the association of pellet and ooid grainstone around the bases of stromatolites suggests deposition in a relatively high-energy, low intertidal environment. Occasionally, crossbed sets of grainstone, which overlie stromatolites, dip in opposite directions, and the resulting "herringbone" fabric is thought to be typical of shallow subtidal and low intertidal sites of deposition (Klein, 1972, p. 400).

Oolite and other mud-free grainstones indicate sustained moderate to high turbulence in warm and probably clear water. Ooid formation requires frequent agitation of the sand-sized grains, and other spar-rich grain-supported rocks suggest that mud was winnowed from the sediment by frequent agitation. Evidence was not found for diagenetic alteration (neomorphism) of micrite to pseudospar in the thin sections and acetate peels made of Whitehall limestones (Halley, 1971a).

Hypersalinity or highly fluctuating salinity in the Whitehall depositional environment may be suggested by the abundance of high-relief domal stromatolites and by the presence of length-slow chalcedony. Recent high-relief domal stromatolites are uniquely associated with hypersaline environments in Shark Bay, Western Australia (Logan, 1961, p. 518; Hoffman and others, 1969; also compare Logan and others, 1970, fig. 7B; Logan and Cebulski, 1970, fig. 6).

Folk and Pittman (1971) recently presented strong evidence that length-slow chalcedony forms

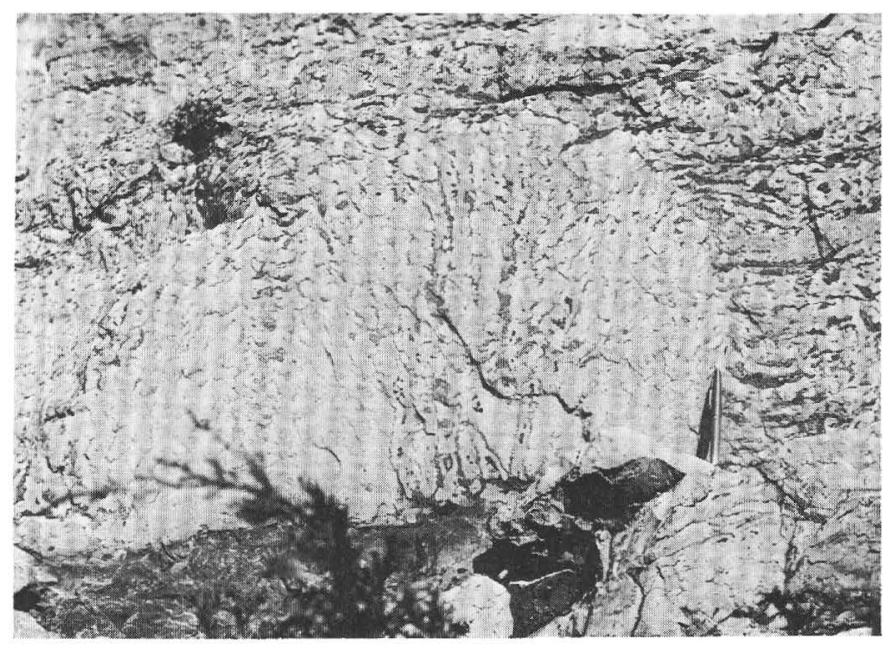

Figure 5.-Domal thrombolite in the lower Whitehall Formation, Crossman quarry. A 6-inch-long $(15 \mathrm{~cm})$ pen placed in the lower right corner of photograph is at the contact between a thrombolite (left) and planar-bedded grainstone (right). Dark material is chert. 
predominantly in association with evaporitic deposits. The relatively low solubility and persistence of length-slow chalcedony in carbonate deposits that lack more obvious evidence for evaporites suggest that occurrence of the mineral may be used as an indicator of evaporitic conditions. Length-slow chalcedony occurs in the Whitehall Formation as void fill within some fenestrae of nonclastic thrombolites (pl. 4, fig. 3) and as cements in some grainstones. However, the time of emplacement of the Whitehall chalcedony is unknown so that it is not now possible to differentiate between an early diagenetic origin in contact with primary hypersaline marine waters, or late diagenetic origin from hypersaline waters flushed through the Whitehall beds from other evaporitic horizons.

It may be noteworthy however, that almost half the examples of length-slow chalcedony cited by Folk and Pittman (1971, p. 1052-1053) are from Cambrian and Ordovician carbonate rocks, many of which are stromatolitic. Thus, the association of domal stromatolites and length-slow chalcedony in the Whitehall Formation may be tentatively accepted as evidence of hypersaline conditions. Absence of remains of infaunal organisms and echinoderms from the Whitehall rocks is consistent with hypersaline conditions in the depositional environment.

The geographic setting of the Whitehall cryptalgal limestones was probably the inner, landward (cratonal) side of the carbonate shelf. (See "Biofacies Distribution.") Shoreline deposits of the Whitehall are associated with well-rounded quartz sand grains. The quartz grains are diagenetically etched, and parts of the grain edges have been replaced by calcite. Diagenetic alteration of grain surfaces precludes an interpretation of the transport mode of these grains (Margolis, 1968, p. 255). However, the presence of quartz sand in the Whitehall indicates that these deposits were not isolated from a clastic source, here probably the exposed craton. The quartz sand suggests that Whitehall shorelines were probably near the exposed cratonal margin rather than on carbonate islands which may have existed near the outer edge of the shelf. Field evidence for the width of the Whitehall carbonate shelf is inconclusive because the seaward edge is obscured by the allochthonous Taconic sequence a few miles east of the study area (Theokritoff, 1964; fig. 1, this report).

The frequency with which evidence of shorelines is found in the Whitehall sections indicates that the contained faunas probably lived relatively near shore. No fossils were found uniquely associated with intertidal lithologies, and it is thus presumed that the animals lived in nearby shallow subtidal habitats.

In summary, the Whitehall fossils represent a vagile epibenthic fauna that probably lived in a nearshore subtidal habitat characterized by warm and clear marine waters. The habitat probably experienced sustained moderate to high turbulence and may have had a high range of salinity or generally hypersaline conditions. The geographic site of deposition was probably on the landward edge of a carbonate shelf of unknown width.

\section{BIOFACIES DISTRIBUTION}

\section{MODELS}

Two major facies models have been proposed to explain the distribution of North American Cambrian trilobite faunas. The first was presented by Lochman and Wilson (1958) who recognized three biofacies "realms" which were thought to be concentrically arranged around the North American craton and tectonically controlled. Lochman (1970, 1971) recently reviewed and updated the earlier model for part of the North American area. In the latter studies, Lochman recognized two major biofacies: (1) A "cratonic" biofacies, consisting of "Pacific province" assemblages occurring in cratonal and miogeosynclinal sites, and (2) an "extracratonic" biofacies, consisting of "Atlantic province" assemblages which occur in outer miogeosynclinal and eugeosynclinal areas. The Whitehall Saukia Zone fauna is near the outer limits of the cratonic biofacies as interpreted by Lochman (1970, fig. 7) for New York State.

Palmer (1960, 1965, 1968, 1969, 1971a, b, 1972a, 1973) has developed a second model of Cambrian trilobite- and sediment-distribution patterns that is based on the recognition of three more or less coincident biofacies and lithofacies belts concentrically arranged around the North American craton. The model differs from that of Lochman and Wilson by placing greater emphasis on sedimentary depositional patterns and contained fossils, rather than on geotectonic criteria. Palmer's lithofacies belts have been termed: (1) an "inner detrital belt," characterized by terrigenous clastic rocks dominated by quartzose and feldspathic sandstone, glauconitic sandstone, and varying amounts of shale and carbonate rocks, (2) a "carbonate belt" characterized by generally high-mechanical-energy coarse-textured bioclastic sparry limestones, oolitic and pisolitic limestones, 
high-relief stromatolites, massive accumulations of light-colored lime mudstone and dolomite, and (3) an "outer detrital belt" characterized by darkcolored shales, siltstones, and intercalated thinly bedded limestones which are commonly pyritic and carbonaceous. Each lithofacies belt has been postulated to contain a particular trilobite fauna characterized by differences in relative abundance and particular associations of genera and species (Palmer, $1968,1969)$. The model reflects a broad shallowwater depositional shelf with inner-shelf terrigenous clastic environments grading seaward to outer-shelf carbonate shoals and tidal flats, which in turn grade oceanward to basinal (below maximum effective wave base) sedimentary environments.

Palmer's model seems to have greater heuristic value than the earlier model (Lochman and Wilson, 1958; Lochman, 1970, 1971) for several reasons: (1) The model separates rocks and contained faunas from the a priori genetic implications of the geotectonic categories "cratonal shelf," "miogeosyncline," and "eugeosyncline." The sedimentary model implies a more or less continuous transition of environments from shoreline to continental shelf margin, rather than a sharp division into cratonal and miogeosynclinal sedimentary environments. Sloss (1960) has stressed the similarity of early Paleozoic sedimentary sequences in cratonal and miogeosynclinal sites in the Western United States, and data presented by Lochman (1971, figs. 21-24) show that Trempealeauan sedimentary facies patterns are not closely correlated with geosynclinal areas, (2) the model can be applied to critical analyses of the relative influence of eustatic and epeirogenetic factors in the regional control of lithofacies distribution, and (3) the model is more reflective of inferred Cambrian paleogeography and thus is more easily compared with recent geographic conditions. Therefore, it may provide a regional framework for studies of paleoecology, adaptive radiation in space and time, and more detailed analyses of the significance of biogeographic distribution patterns.

\section{METHODS OF ANALYSIS}

An historically meaningful biogeographic (biofacies) analysis ideally should be based on critically studied taxa to insure that concepts of all operational taxonomic units are consistently applied throughout the area to be analyzed. The present state of knowledge of North American Saukia Zone trilobite faunas falls short of this ideal. Taxonomic data are unevenly developed. Some areas have been subjected to intensive collecting and systematic study (for example, central Texas and Oklahoma), whereas some other areas have a variety of problems, such as relatively incomplete systematic study (for example, Upper Mississippi Valley) and early systematic work that needs reevaluation (for example, New Jersey and, in part, Vermont) ; in some areas, faunas are known only from lists (for example, Taconic sequence of New York and western Newfoundland). These factors limit the reliance that can be placed on numerical analyses of biogeographic distribution patterns. However, it seems useful to examine distribution patterns, even though possible interpretation is limited at present.

Simpson's (1960, p. 301) index of faunal resemblance (IFR) is used here to determine the degree of apparent biofacies similarity between the Saukia Zone trilobite fauna at Whitehall and at other North American sites (fig. 6). IFR is calculated from the equation IFR $=C / N \times 100$, where $C$ equals the number of taxa in common between two samples and $N$ equals the number of taxa in the smaller of two samples. IFR values were calculated for both species and genera that occur at Whitehall. Results are shown in tables 3 and 4.

Simpson (1960) has discussed the advantages and disadvantages of his index in paleontological studies and Mello and Buzas (1968), and Cheetham and Hazel (1969) have compared the index with other numerical indexes. In general, IFR minimizes effects of differences in sample size (Simpson, 1960, p. 301) and tends to emphasize similarity (Cheetham and Hazel, 1969, p. 1135). IFR can become strongly biased when large discrepancies exist in sample size. When the number of taxa in the smaller sample $(N)$ approaches the number in common $(C)$ between two samples, excessively high IFR values result. However, calculated values provide an objective and explicit basis for discussion of regional faunal similarities if limitations are recognized and differences in IFR are cautiously interpreted.

\section{ASSEMBLAGES SIMILAR TO WHITEHALL FAUNA}

Analysis of species-level faunal resemblance with the Whitehall Saukia Zone fauna shows a range in IFR values from 25 to 63 for the east-central Great Basin (Notch Peak and Whipple Cave Formations), Llano region of central Texas (Wilberns Formation), Arbuckle Mountains of Oklahoma (Signal Mountain Formation), and the central Appalachian 


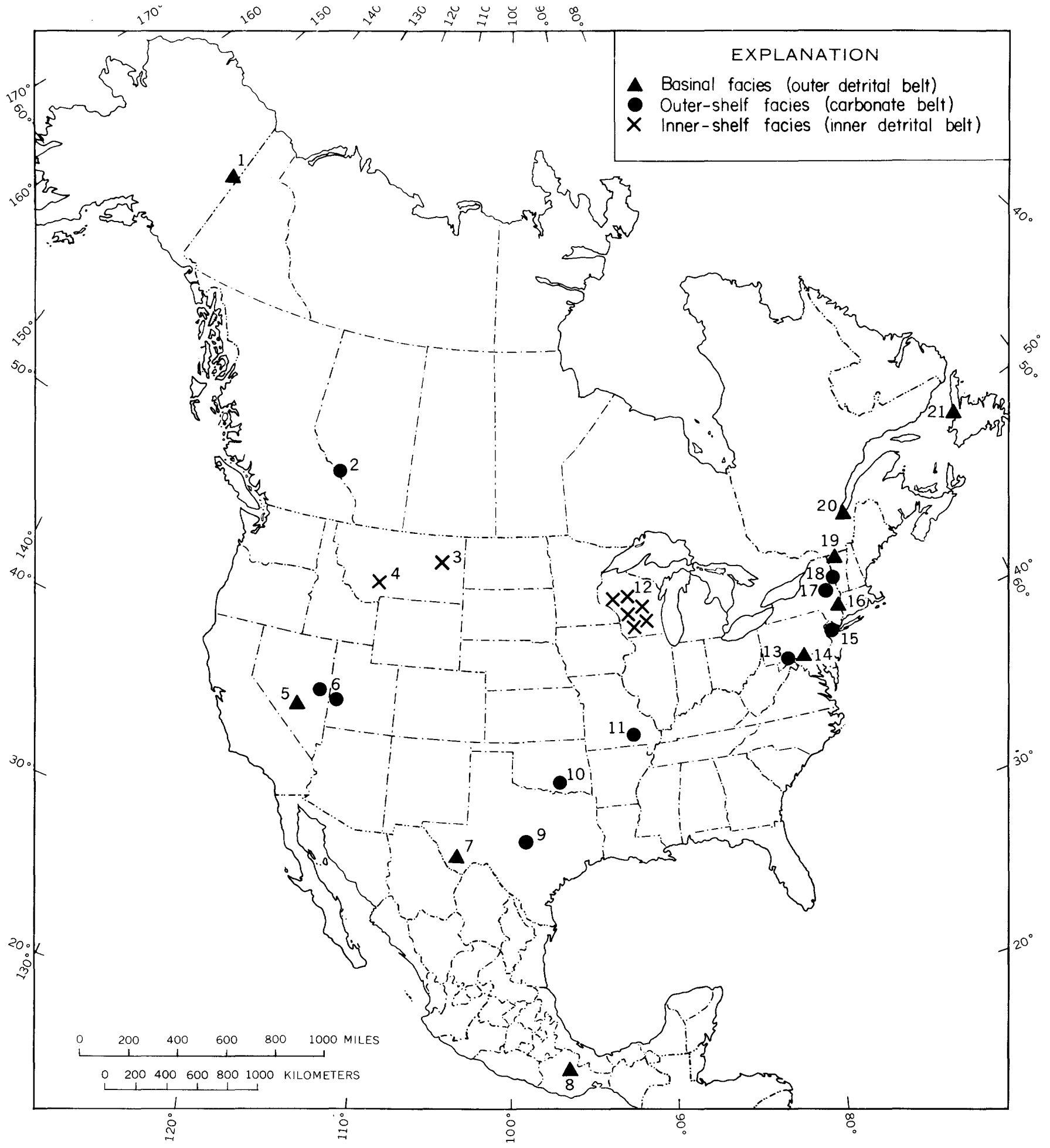


region (Conococheague Limestone). Faunal resemblance at the generic level shows an increase in degree of similarity ranging from 63 to 87 for the same areas; high resemblance is also shown with the fauna of the Mount Wilson area of Alberta (Mistaya and Survey Peak formations), the Eminence region (Eminence Dolomite) of Missouri, the Upper Mississippi Valley (Trempealeauan Stage), and perhaps northwestern New Jersey (Kittatinny Limestone).

Lithologic analysis of containing rocks provides evidence for the existence of a shallow-water carbonate bank in some of those areas showing high IFR values with the Whitehall Saukia Zone fauna. Studies of Upper Cambrian rocks in the Mount Wilson area of Alberta (Aitken and Norford, 1967; Aitken, 1967) and in central Texas (Ahr, 1971) show that in those areas the Saukia Zone interval is characterized by coarse-textured skeletal grainstones, oolitic and pisolitic grainstones, flat-pebble conglomerates, and both laminar and nonlaminar algal boundstones. The characteristics of these diverse rock suites are consistent with those here described for the Whitehall Formation and are thought to reflect origin in shallow subtidal to tidal-flat environments. (See, for example, Laporte, 1971.) Detailed petrographic studies have not been made in the other areas. However, field studies of strata containing the Saukia Zone fauna in the east-central Great Basin (Taylor, 1969, 1971) report an abundance of flat-pebble conglomerate, skeletal and oolitic grainstones, and laminar and nonlaminar limestone mounds that may prove similar to those described by Aitken (1967) from Albərta and Ahr (1971) from central Texas. Stitt (1971) reported similar rock types in the Signal Mountain Limestone of southcentral Oklahoma, and the Conococheague Limestone has been characterized (Wilson, 1952; Sando, 1957) as commonly containing oolites, flat-pebble conglomerates and "cryptozoan" beds. Detailed data on the fauna and lithologic characteristics of the Kittatinny Limestone of New Jersey are few so that further study is needed to clarify the faunal and environmental relationships with other Upper Cambrian sites.

The widespread distribution, high degree of faunal similarity, and association with grossly similar sedimentary environments suggests that the Whitehall Saukia Zone fauna is part of a near-sea-level shelf carbonate biofacies that seems to be oriented concentrically around the North American Late Cambrian cratonal region.

The Saukia Zone fauna from the Upper Mississippi Valley area shows a high degree of generic-level similarity (IFR $=87$ ) with the carbonate shelf biofacies typified by the Whitehall fauna, even though terrigenous clastic deposition dominates that area (Nelson, 1956; Lochman, 1971). Such a high degree of faunal similarity is inconsistent with the Palmer model of distinct inner detrital belt and carbonate belt biofacies. The discrepancy cannot be critically evaluated at present because taxonomic information on the Upper Mississippi Valley Trempealeauan fauna is available only for the relatively large trilobites of the families Dikelocephalinae and Saukiinae, whereas the presence of most other taxa are only known from faunal lists (Nelson, 1951; Raasch, 1951). On the other hand, the low IFR value between Whitehall (carbonate shelf facies) and northeastern and southwestern Montana (Lochman, 1964a; Grant, 1965) (detrital shelf facies) suggests that some faunal differences may be present between these two areas. Further taxonomic work is needed to elucidate biofacies differences and similarities between outer and inner shelf sites during Trempealeauan time.
Figure 6.-Map showing the general location of principal areas of North America from which Saukia Zone faunas have been reported. See text for discussion. Sources of data: (1) East-central Alaska (Palmer, 1968) ; (2) Mount Wilson, Alberta (Derby and others, 1972); (3) McCone County, Mont. (Lochman, 1964a); (4) southwestern Montana (Grant, 1965) ; (5) central Nevada and (6) eastern Nevada-western Utah (Taylor, 1971); (7) Marathon basin, Texas (Wilson, 1954, 1956); (8) Oaxaca, Mexico (Robison and Pantoja-Alor, 1968) ; (9) Llano uplift, Texas (Longacre, 1970); (10) Arbuckle Mountains, Okla. (Stitt, 1971); (11) Eminence region Missouri (Ulrich, 1930); (12) Upper Mississippi Valley (Nelson, 1951; Raasch, 1951);
(13) central Appalachian Mountains, Conococheague Formation, and (14) central Appalachian Mountains, Frederick and Grove Formations (Rasetti, 1959) ; (15) northwestern New Jersey (Howell, 1945) and observations, this report; (16) Taconic sequence, eastern New York State (Bird and Rasetti, 1968); (17) Saratoga Springs, N.Y. (Walcott, 1912b), and observations, this report; (18) Whitehall, N.Y., this report; (19) St. Albans area, Vermont (Raymond, 1924, 1937; Clark and Shaw, 1968), and some taxonomic reassignments, this report; (20) Lévis area, Quebec (Rasetti, 1944, 1945, 1963); (21) Broom Point, western Newfoundland (Kindle and Whittington, 1959). 
TABLE 3.-Known occurrences of trilobite species recognized from the Saukia Zone at Whitehall, N.Y.

[Simpson's (1960) index of faunal resemblance (IFR) is a rough meas ure of the degree of apparent biogeographic similarity between Whitehall and other areas where the species are known. Data-source numbers in parentheses are explained in fig. 6 . Explanation of symbols: $X$, established occurrence; --, not known to occur; ?, questionable identification; *, insufficient data for computation. See text for discussion of each area]

\begin{tabular}{|c|c|c|c|c|c|c|c|c|c|c|c|c|c|c|c|c|c|c|c|c|}
\hline Area & 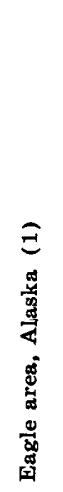 & 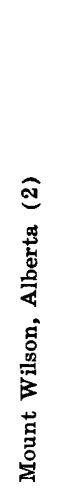 & 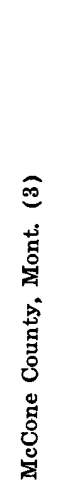 & 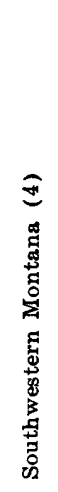 & 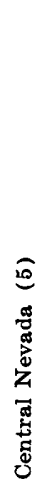 & 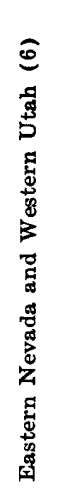 & 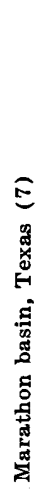 & 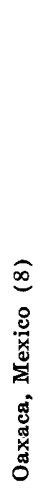 & 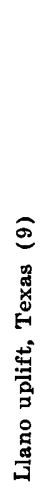 & 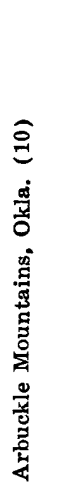 & 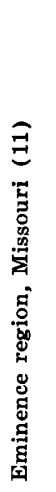 & 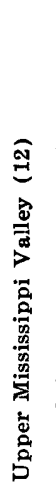 & 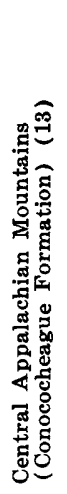 & 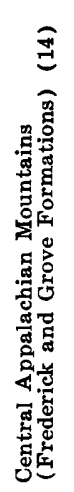 & 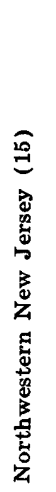 & 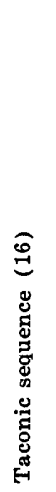 & 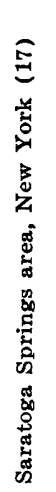 & 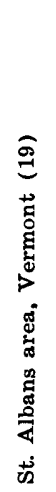 & 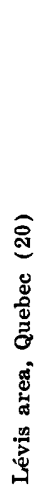 & 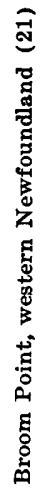 \\
\hline $\begin{array}{l}\text { Acheilops masonensis Winston and Nicholls } \\
\text { Bowmania cf. B. pennsylvanica Rasetti } \\
\text { "Calvinella" prethoparia Longacre } \\
\text { Euptychaspis typicalis Ulrich } \\
\text { Plethometopus obtusus Rasetti } \\
\text { Plethometopus sp. A } \\
\text { "Prosaukia" spinula Taylor, n. sp } \\
\text { Stenochilina sp. A }\end{array}$ & $\bar{z}$ & $\begin{array}{l}-- \\
-- \\
-- \\
-- \\
-- \\
-- \\
-- \\
--\end{array}$ & $\begin{array}{l}- \\
- \\
- \\
-\end{array}$ & $\begin{array}{l}-- \\
-- \\
-- \\
-- \\
-- \\
-- \\
-- \\
--\end{array}$ & $\begin{array}{l}- \\
- \\
\overline{-} \\
-\end{array}$ & $\begin{array}{l}x \\
\bar{?} \\
\overline{-} \\
- \\
-\end{array}$ & $\begin{array}{l}- \\
- \\
- \\
-\end{array}$ & $\overline{-}$ & $\begin{array}{l}x \\
x \\
x \\
x \\
x \\
- \\
-\end{array}$ & $\begin{array}{l}x \\
x \\
x \\
x \\
- \\
-\end{array}$ & $\begin{array}{l}- \\
\bar{x} \\
- \\
- \\
-\end{array}$ & $\begin{array}{l}-- \\
-- \\
-- \\
-- \\
-- \\
-- \\
-- \\
--\end{array}$ & $\begin{array}{l}\bar{x} \\
\bar{x} \\
x \\
- \\
-\end{array}$ & $\begin{array}{l}\bar{?} \\
- \\
- \\
- \\
-\end{array}$ & $\begin{array}{c}- \\
\bar{x} \\
\overline{-} \\
-\end{array}$ & $\begin{array}{l}-- \\
-- \\
-- \\
-- \\
-- \\
-- \\
-- \\
--\end{array}$ & $\begin{array}{l}- \\
- \\
- \\
- \\
-\end{array}$ & $\begin{array}{r}- \\
- \\
- \\
- \\
-\end{array}$ & $\overline{-}$ & $\begin{array}{l}-- \\
-- \\
-- \\
-- \\
-- \\
-- \\
-- \\
--\end{array}$ \\
\hline Index of faunal resemblance (IFR) & 0 & $*$ & 0 & $*$ & 0 & $\begin{array}{l}25 \\
\text { to } \\
37 ?\end{array}$ & 0 & 0 & 63 & 50 & 13 & $*$ & 37 & $13 ?$ & 13 & $*$ & 0 & 0 & 13 & * \\
\hline
\end{tabular}

\section{ASSEMBLAGES DISSIMILAR TO WHITEHALL FAUNA}

Faunas from many areas analyzed have low IFR values with the Whitehall fauna at the species level. Causes of the low degree of similarity are probably multiple and perhaps in large part influenced by the varying quality and quantity of taxonomic information and field collecting in the different areas. For this reason, comparisons of generic occurrences should be evaluated cautiously.

Low IFR values, ranging from 0 to 37, were calculated for generic occurrences between the Whitehall fauna and the Eagle area of Alaska; McCone County, Mont.; southwestern Montana; central Nevada; the Marathon region, Texas; Oaxaca, Mexico; the Frederick and Grove Formations of Maryland; Saratoga Springs, N.Y.; the Taconic sequence of eastern New York; the St. Albans area of Vermont; Lévis, Quebec; and western Newfoundland (table 4). Several Saukia Zone occurrences which have low IFR values with the Whitehall fauna are similar to one another and are characterized by the so-called Hungaia magnifica fauna (Rasetti, 1944, 1945, 1963), which is thought to characterize North American "outer detrital belt" (basinal) sites (Palmer, 1969, 1972b). Such areas include the Eagle area of Alaska; central Nevada (in part) ; the Marathon region of Texas; the Frederick and Grove Formations of Maryland; the Taconic sequence of eastern New York; the St. Albans area, Vermont; Lévis, Quebec; and western Newfoundland. The occurrence of the Hungaia fauna seems to be related to basinal sedimentary environments or shelf-edge carbonates that may occur as subsequent or penecontemporaneous allochthonous debris flows into basinal environments (Kindle and Whittington, 1958, p. 340 ; also see Bird and Dewey, 1970, fig. 7a).

The low IFR value between the Trempealeauan fauna at Saratoga Springs and Whitehall is an enigma that cannot be satisfactorily explained at present. The Hoyt trilobite fauna is dissimilar to all other described faunas except for the occurrence of the ubiquitous Plethometopus, Plethopeltis, and "Prosaukia" (a species not closely related to the Whitehall form). The differences between the Hoyt and Whitehall faunas may be a result of difference in age, but if this is true one might expect to find the Hoyt fauna in the carbonate facies of Saukia subzones in the relatively well known sections in Oklahoma, Texas, and the Great Basin. However, the fauna has not been discovered in these areas in spite of a considerable amount of collecting. This suggests 
TABLE 4.-Known North American occurrences of trilobite genera recognized from the Saukia Zone at Whitehall, N. Y.

[Simpson's (1960) index of faunal resemblance (IFR) is a rough meas ure of the degree of apparent biogeographic similarity between Whitehall and other areas of occurrence. Data-source numbers given in parentheses are explained in fig. 6. Explanation of symbols: $X$, established occurrence; -, not known to occur; ?, questionable identification; *, insufficient data for computation. See text for discussion of each area ]

\begin{tabular}{|c|c|c|c|c|c|c|c|c|c|c|c|c|c|c|c|c|c|c|c|c|}
\hline Area & 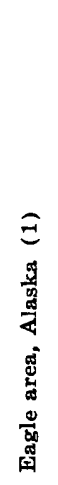 & 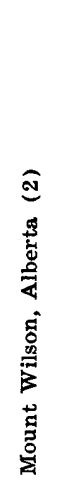 & 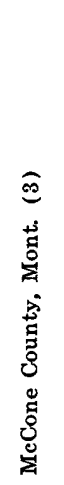 & 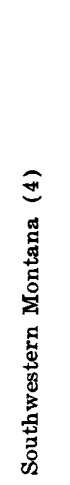 & 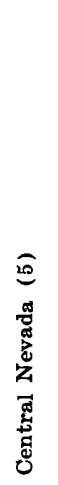 & 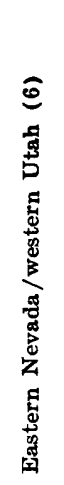 & 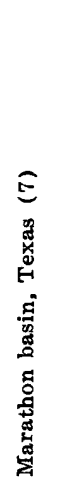 & 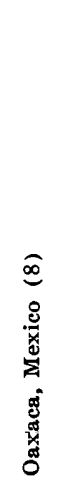 & 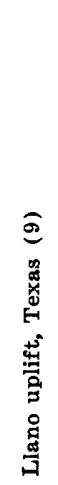 & 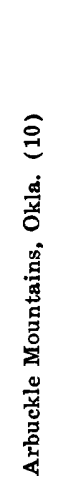 & 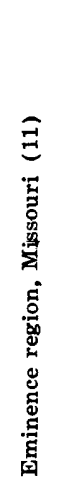 & 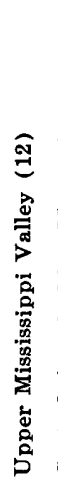 & 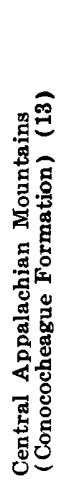 & 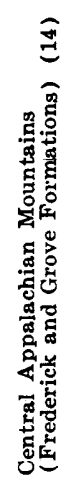 & 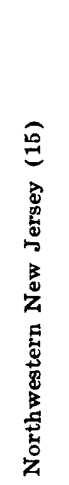 & 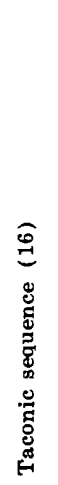 & 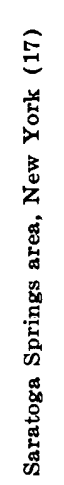 & 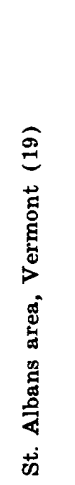 & 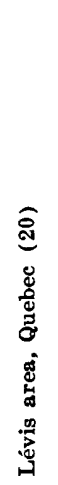 & 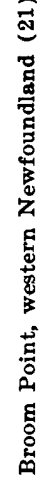 \\
\hline $\begin{array}{l}\text { Acheilops Ulrich } \\
\text { Bowmania Walcott } \\
\text { "Calvinella", Walcott } \\
\text { Euptychaspis Ulrich } \\
\text { Plethometopus Ulrich } \\
\text { Plethopeltis, Raymond } \\
\text { "Prosaukia" Ulrich and Resser } \\
\text { Stenochilina Ulrich }\end{array}$ & $\begin{array}{l}z \\
z \\
z \\
z\end{array}$ & $\begin{array}{l}\bar{x} \\
x \\
x \\
x \\
= \\
-\end{array}$ & $\begin{array}{l}\bar{z} \\
\bar{x} \\
z \\
z\end{array}$ & $\begin{array}{l}E \\
z \\
z \\
z\end{array}$ & $\begin{array}{l}z \\
z \\
z \\
z \\
-\end{array}$ & $\begin{array}{l}\times \\
x \\
x \\
x \\
x \\
x \\
x \\
x \\
-\end{array}$ & $\begin{array}{l}z \\
z \\
z \\
z \\
-\end{array}$ & $\begin{array}{l}E \\
= \\
\bar{E} \\
=\end{array}$ & $\begin{array}{l}x \\
x \\
x \\
x \\
x \\
x \\
x \\
\end{array}$ & $\begin{array}{l}x \\
x \\
x \\
x \\
x \\
x \\
x \\
x \\
-\end{array}$ & $\begin{array}{l}\frac{x}{x} \\
x \\
x \\
x \\
\frac{x}{x}\end{array}$ & $\begin{array}{l}\frac{x}{x} \\
x \\
x \\
x \\
x \\
x \\
-\end{array}$ & $\begin{array}{l}\bar{x} \\
\bar{x} \\
\frac{x}{x} \\
x\end{array}$ & $\begin{array}{l}\bar{?} \\
\overline{\bar{C}} \\
\bar{x} \\
\overline{-}\end{array}$ & $\begin{array}{r}? \\
? \\
? \\
\times \\
\times \\
\times \\
?\end{array}$ & $\begin{array}{l}\bar{z} \\
\bar{z} \\
\bar{z} \\
\overline{-}\end{array}$ & $\begin{array}{l}- \\
\bar{z} \\
\bar{x} \\
x \\
x \\
\bar{x}\end{array}$ & $\begin{array}{l}E \\
\bar{E} \\
\bar{x} \\
\stackrel{?}{x}\end{array}$ & $\begin{array}{l}\bar{z} \\
\bar{x} \\
\overline{-} \\
-\end{array}$ & $\begin{array}{l}- \\
\bar{z} \\
\bar{x} \\
\bar{x} \\
-\end{array}$ \\
\hline Index of faunal resemblance (IFR) & 0 & 50 & 13 & 0 & 0 & 87 & 0 & 0 & 87 & 87 & 75 & 75 & 63 & $\begin{array}{l}13 \\
\text { to } \\
25 ?\end{array}$ & $\begin{array}{l}37 \\
\text { to } \\
87 ?\end{array}$ & 0 & 37 & $\begin{array}{l}25 \\
\text { to } \\
37 ?\end{array}$ & 13 & 25 \\
\hline
\end{tabular}

that the Hoyt fauna probably reflects environmental conditions different from those reflected by the Whitehall fauna.

Halley (1971a) noted that although the Hoyt and parts of the Whitehall Formations contain similar depositional textures, the Hoyt differs in possessing a high content of carbonaceous residue and dolomite and lacks chert and length-slow chalcedony. Also, the Hoyt fauna contains representative elements of a greater number of phyla than does the Whitehall. Walcott (1912b) reported gastropods, trilobites, and inarticulate brachiopods from the Hoyt, and Halley (1971a) found echinoderm and dasycladacean algal fragments. (See pl. 4, figs. 7, 8.) Inarticulate brachiopods, dasycladacean algae, and echinoderm plates were searched for but not identified from the Whitehall limestones. The absence of echinoderms from the Whitehall samples and the absence of length-slow chalcedony from the Hoyt suggest that the Hoyt fauna may have lived in a more normal saline environment than the Whitehall fauna. Although no quantitative estimate of the salinity fluctuations of the two areas can presently be made, it is reasonable to infer that either the magnitude or the periodicity of salinity fluctuations was less in the Hoyt depositional environment than in that of the Whitehall Formation. Such environmental differences could account for faunal dissimilarity between the two areas. However, further study in the Saratoga Springs area is needed to clarify the causes of faunal dissimilarity between the Hoyt, Whitehall, and other carbonate belt sites in North America.

The McCone County area of Montana (Lochman, 1964a) has only one genus reported in common with the Whitehall area. The site is characterized by intercalated terrigenous shale and limestone-pebble conglomerate (Lochman and Wilson, 1967), suggesting, together with the faunal evidence, that the area was part of an inner shelf facies.

Grant $(1965$, p. 88) reported Trempealeauan fossils from part of the Snowy Range Formation in southeastern Montana and adjacent Wyoming, which he assigned to the Illaenurus Zone. The zone contains no species or genera in common with the Whitehall assemblages. However, the Illaenurus Zone is probably early Trempealeauan in age (Grant, 1965; Longacre, 1970) so that differences between it and Whitehall could be due to temporal rather than environmental factors. 
Faunas described from Oaxaca, Mexico, differ markedly from both the Hungaia magnifica biofacies and the inner shelf biofacies which also shows low IFR values. The Oaxaca fauna may be classified as basinal facies, but it is most similar to described faunas from Argentina and the Tremadocian facies of eastern Canada, Great Britain, and Scandinavia (Robison and Pantoja-Alor, 1968, p. 772) rather than the North American basinal Hungaia magnifica biofacies.

The methods used here for measuring faunal resemblance do not allow quantitative conclusions concerning the homogeneity or heterogeneity of the Saukia Zone biofacies belts. Estimates of homogeneity or heterogeneity rely on subjective evaluation of faunal lists, published formal taxonomic studies, and museum collections.

On the basis of the published and newly described faunal evidence, however, (Taylor, and other 1971, unpub. data), the Upper Cambrian carbonate-shelf facies seems to have a relatively homogeneous trilobite fauna. In contrast, North American basinal facies sites seem to be occupied by at least two faunas, the Hungaia magnifica biofacies and the Tremadocian faunas described from Mexico (Robison and Pantoja-Alor, 1968), and perhaps a third -the Hedinaspis fauna-in Alaska (Palmer, 1968) and the central Great Basin (Taylor, 1971, and other unpub. data).

Rowell and McBride (1972a, c), Rowell, McBride, and Palmer (1973) recently made a quantitative study of Trempealeauan trilobite distribution in North America using multivariate-analysis techniques applied to nearly all the available trilobite data. Some results of their study were the recognition of a "North American faunal province" that is divisible into two "subprovinces," a restricted shelf subprovince (inner-shelf detrital and outershelf carbonate facies of this report) and a shelf margin-open ocean subprovince (basinal facies of this report). The analysis by Rowell, McBride, and Palmer (1973) supports earlier suggestions (Rowell and McBride, 1972b) that faunas of the marginal shelf-open ocean (Tremadocian of Mexico and Hedinaspis basinal biofacies of this report) are geographically heterogeneous and have affinities with either Asia or Europe.

Many terminological differences exist between the report by Rowell, McBride, and Palmer (1973) and this one. However, an important conclusion to be made at this time is the general agreement that for the North American Trempealeauan, the great- est faunal change occurs between the outer-shelf carbonate biofacies and the offshelf basinal biofacies. Further understanding of possible causes of observed patterns of trilobite distribution will probably result from greatly needed detailed sedimentological studies of the rocks enclosing the various faunas and from taxonomic studies of trilobites from those areas for which available data are insufficient or obsolete.

\section{SYSTEMATIC PALEONTOLOGY INTRODUCTORY STATEMENT}

Trilobite morphological terminology used in the systematic descriptions follows the "Treatise on Invertebrate Paleontology, Part 0" (Harrington and others, 1959) except that nomenclature for glabellar furrows and lobes follows Henningsmoen $(1957$, p. 13) : lateral glabellar furrows are numbered forward from the posterior end, beginning with S0 (occipital furrow) and proceeding S1, S2, S3, and S4; lateral glabellar lobes are also numbered forward from the posterior end beginning with $\mathrm{LO}$ (occipital lobe), and proceeding L1, L2, L3, and L4. Henningsmoen's system is preferred here over the Treatise system because it usually results in an economy of words without loss of precision in telegraphic descriptions, and it lacks the ambiguity of the $1 p, 2 p$, and so forth, system advocated in the Treatise by providing separate notation for lobes and furrows.

Economy of words in systematic descriptions is also made possible by the use of several other terms in Henningsmoen's system (1957, p. 12-14). These terms, together with the Treatise equivalent in parentheses, are as follows: Preocular suture (anterior section of facial suture), postocular suture (posterior section of facial suture), anterior fixigena (anterior area of fixigena), interocular fixigena (palpebral area of fixigena), posterior fixigena (posterior area of fixigena), and ocular incisure (no Treatise term).

The terms "corner angle," "inner spine angle," and "outer spine angle" (Henningsmoen, 1957) are simple and useful for describing angles in the genal corner region of librigenae. The term "eye socle" is used, following Shaw and Ormiston (1964), in preference to "eye platform."

Gill $(1949$, p. 572) proposed that the term "prosopon" be used in place of "ornament" in the description of surface appearance of fossil specimens to deemphasize the nonfunctional connotation of the term ornament. (Also see Wright, 1950; Gill, 1951.) 
The surface appearance of trilobites is highly variable. Some forms have surface sculpture consisting of anastomosing ridges, bertillion pattern, and other features of uncertain functional significance, whereas others have various kinds of perforate tubercles or surface pits that probably were functionally related to sensory setae in the living animal. An added difficulty arises in description of the surface appearance of molds and casts. For example, features visible on internal molds of exoskeletal parts are a negative replica of the inner, or visceral, surface of the exoskeleton. "Ornament" seems particularly incongruous in the description of such features. Therefore, Gill's usage of prosopon has been adopted here as a descriptive term for the surface appearance of fossils. In trilobite descriptions, this usage is applicable to inner and outer actual surfaces, internal and external molds, and internal and external casts of exoskeleton parts.

\section{Class TRILOBITA Walch, 1771 \\ Family CATILLICEPHALIDAE Raymond, 1938 \\ Genus ACHEILOPS Ulrich, 1931}

Acheilops Ulrich in Bridge, 1931, p. 218; Kobayashi, 1942, p. 174; Rasetti, 1954, p. 611; Winston and Nicholls, 1967, p. 77.

Type species.-Acheilops dilatus Ulrich in Bridge, 1931, by original designation.

Diagnosis.-Catillicephalid trilobites with palpebral lobes that range in length from approximately 0.3 to 0.4 of cranidial length (exsagittal (exsag.)) and center posterior to the cranidial midpoint opposite S1. Posterior fixigenae are subparallel sided. Frontal area and anterior fixigenae are absent.

Discussion.-Winston and Nicholls (1967, p. 77) discussed the characteristics of Acheilops and gave reasons for its inclusion in the Catillicephalidae. Their classification is followed here.

There are apparently three nominal species of Acheilops: Acheilops dilatus, the type species from near Eminence, Mo.; Acheilops masonensis Winston and Nicholls, 1967, from the Wilberns Formation of central Texas; and Acheilops norwalkensis Ulrich and Resser, 1930, from Monroe County, Wis. Acheilops norwalkensis was illustrated (Ulrich and Resser, 1930, pl. 21, fig. 8) but apparently never described. However, the name is available under the rules of the International Code on Zoological Nomenclature (1964), Article 12, by indication. The slab illustrated by Ulrich and Resser contains two cranidia attributable to Acheilops. Both have axial glabellar furrows, which diverge in the region of the interocular fixigena and have faint but complete palpebral furrows and lunate palpebral lobes which are centered posterior to the glabellar midpoint and opposite the S1 furrows.

The type collection of $A$. dilatus could not be located in the USNM collections, nor could any other specimens be located among material from the type locality (102j, old series). This constitutes a dilemma as $A$. dilatus is the type species of the genus. The problem is compounded by the fact that the original material was collected from residual cherts near Eminence, Mo. Thus, topotype material cannot be objectively recollected. Fortunately, the concept of Acheilops seems sufficiently well characterized on the basis of Ulrich's original description and Winston and Nicholls' description of $A$. masonensis; designation of a neotype does not seem necessary at present.

Acheilops norwalkensis is similar to A. dilatus as illustrated and described by Ulrich (1930, p. 219, pl. 19, figs. 21, 22). Two differences can be noted in comparison with Ulrich's description of $A$. dilatus. $\mathrm{He}$ described the palpebral regions of $A$. dilatus as being "apparently always without furrows(s)." However, as pointed out by Winston and Nicholls (1967, p. 77), the furrows are shown in Ulrich's illustrations (1930, pl. 19, figs. 20-22) of the types.

In Ulrich's (1930, p. 219) original discussion of A. dilatus, he referred to a form, not mentioned by name, from Monroe County, Wis., which differs from $A$. dilatus in having a "greater longitudinal convexity of the anterior half of the glabella." This probably refers to $A$. norwalkensis and seems to be the only morphological difference between it and $A$. dilatus that can be detected from the information and material currently available.

\section{Acheilops masonensis Winston and Nicholls \\ Plate 1, figures 4, 5}

Acheilops masonensis Winston and Nicholls 1967, p. 77, pl. 11, figs. 23-25; Longacre, 1970, p. 15, pl. 6, fig. 19; Stitt, 1971, p. 15, pl. 7, fig. 5 .

Material available.-One cranidium and one librigena from locality $470 \mathrm{~b}$ and one cranidium from locality $\mathrm{H}-3$.

Description of Whitehall material.-Cranidium subtrapezoidal in outline, strongly convex sagittally. Glabella expanded anteriorly, basal width 0.8 length. Axial glabellar furrows deeply impressed. Two pairs lateral glabellar furrows. S1 shallow, geniculate. S2 shallow, nearly transverse, not connected across 
midline. Occipital ring simple, slightly convex, posterior edge rounded, medial region not preserved. Occipital furrow deep. Frontal area not differentiated from glabella. Anterior border and border furrow absent. Anterior fixigena absent. Interocular fixigena lunate, poorly differentiated from palpebral lobes. Postocular fixigena subparallel sided, length (transverse (tr.)) 0.8 occipital lobe length (tr.). Palpebral lobes large, nearly flat, lunate, length (exsag.) 0.3 cranidial length, centered opposite S1. Palpebral furrow faintly developed on posterior onethird of palpebral region. Preocular facial sutures strongly divergent, coursing coincident with anterior parts of axial glabellar furrows. Postocular facial sutures transverse, nearly straight.

Librigena length approximately four times width, nearly vertical in life position. Genal field not differentiated from border. Eye socle with attached holochroal visual surface. Genal spine short, bluntly pointed.

Prosopon consists of closely spaced coarse granules on the external surface except in furrows and branching ridges on the anterior lobe of the glabella and librigena.

Discussion.-Acheilops masonensis has been reported from the Saukiella serotina and Corbinia apopsis Subzones in the Wilberns Formation of central Texas (Winston and Nicholls, 1967; Longacre, 1970). In the original description, Winston and Nicholls (1967) noted that some specimens attributed to $A$. masonensis have shallow lateral glabellar furrows, whereas others possess rather deeply impressed furrows. The Whitehall specimens are most similar to the shallow-furrowed Texas forms (see Longacre, 1970, pl. 6, fig. 19) except that they are more coarsely granular and the palpebral furrows are present only on the posterior part of the palpebral region.

Stitt (1971) reported $A$. masonensis from the Saukiella junia and Saukiella serotina Subzones in the Signal Mountain Formation of south-central Oklahoma. The New York form differs from the specimen illustrated by Stitt (1971, pl. 7, fig. 5) in having shallower lateral glabellar furrows. Stitt noted that some forms high in the range of $A$. masonensis in Oklahoma possess coarser granules than earlier forms. This phenomenon is similar to that shown by the New York specimen.

The New York material differs from $A$. norwalkensis (on USNM 72700) from Monroe County, Wis., in having an incomplete rather than complete palpebral furrow, relatively shorter (exsag.) palpe- bral lobe (exsag. length/cranidial length 0.3 rather than 0.4), and axial glabellar furrows that are subparallel rather than divergent in the interocular fixigenal region.

Occurrence.-Saukiella serotina Subzone, localities H-3 and 470b, Washington County, N.Y.

\section{Genus STENOCHILINA Ulrich, 1931}

Stenochilina Ulrich in Bridge, 1931, p. 215. Rasetti, 1954, p. 606; Rasetti, in Harrington and others, 1959, p. O285.

Type species.-Stenochilina spinifera Ulrich in Bridge, 1931, by original designation.

Diagnosis.-Glabella subparallel sided, rounded to bluntly rounded anteriorly; frontal area narrow, lacking anterior border; palpebral lobes anterior to glabellar midpoint, centered opposite L2 lobe, below level of interocular fixigena; occipital spine present or absent; prosopon coarsely granular.

Discussion.-Rasetti's (1954, 1959) diagnosis of Stenochilina is slightly modified to accommodate features observed in Stenochilina sp. A from New York. The principal change is to include forms that lack an occipital spine.

Rasetti (1954, p. 606) restricted Stenochilina to S. spinifera, the type species from the Trempealeauan near Eminence, Mo. Stenochilina spinifera has also been reported from the Conococheague Formation in Washington County, Md. (Rasetti, 1959, p. $383)$.

Stenochilina is most similar to Triarthropsis from which it differs in the presence of larger, welldefined, anteriorly located palpebral lobes and coarse granular prosopon.

\section{Stenochilina sp. A \\ Plate 1, figures 6-10}

Material available.-Eight cranidia from locality. 418 e (old series).

Description.-Cranidium subtrapezoidal in outline, moderately convex. Glabella subparallel sided, nearly straight sided, basal width about 0.9 length, anteriorly truncate. Axial glabellar furrow deep; preglabellar furrow deep, slightly depressed at midline. Two pairs lateral glabellar furrows, deeply impressed. S1 bifurcate, posterior segment geniculate, faintly connected to $\mathrm{S} 0$ in large specimens; anterior segment connected across midline. S2 deeply impressed, connected across midline. S3 absent. S4 present or absent; if present, short, oblique backwards, straight. Occipital ring composite, lacks medial spine or node. Occipital furrow deeply impressed. Frontal area sagittally convex, length about 
0.1 cranidial length, anterior border absent. Anterior fixigena slope anterolaterally about $45^{\circ}$ from horizontal. Interocular fixigena width 0.3 adjacent glabellar width. Posterior fixigena subparallel sided, bent posteriorly, about 0.8 occipital lobe width (tr.). Eye ridge absent. Palpebral lobe length (exsag.) approximately 0.5 glabellar length, lunate, flat, below level of interocular fixigena, centered anterior to glabellar midpoint opposite L2. Preocular facial sutures divergent then converging evenly to sagittal line forming rounded anterolateral corners of anterior fixigena. Postocular facial sutures strongly divergent, slightly convex, forming nearly transverse character-state.

Librigena, thorax, and pygidium unknown.

Prosopon consists of evenly spaced coarse perforate(?) granules and closely spaced fine granules in furrows and interspersed between coarse granules.

Discussion.-Stenochilina sp. A differs from the holotype of S. spinifera in the absence of an occipital spine, in having a relatively shorter frontal area (length/cranidial length 0.10 rather than 0.07 in the holotype), a more straight-sided glabella, and in the presence of diminutive $\mathrm{S} 4$ furrows on some individuals.

Material from the Conococheague Limestone of Maryland was assigned to $S$. spinifera by Rasetti $(1959$, p. 383 , pl. 52, figs. 15, 16). The specimens are similar to the New York material in having nearly straight-sided glabellae and diminutive S4 furrows (shown in Rasetti's fig. 15). The only significant difference between the New York and Maryland forms seems to be the presence of an occipital spine in the latter.

The New York material is placed in open nomenclature because of uncertainty as to the precise location of the original collecting site and because the available specimens are few and rather poorly preserved.

Occurrence.-Saukia Zone, locality 418e, Washington County, N.Y.

Family HETEROCARYONIDAE Hupe, 1953, emended Clark and Shaw, 1968 Genus BOWMANIA Walcott, 1925

Bowmania Walcott, 1925 , p. 73 ; Rasetti, in Harrington and others, 1959 , p. O517.

Type species.-Arethusina americana Walcott, 1884 , by original designation.

Diagnosis.-The concept of Bowmania described by Rasetti (in Harrington and others, 1959) is followed here.
Bowmania cf. B. pennsylvanica Rasetti

Plate 2, figures 12-14

Bowmania pennsylvanica Rasetti, 1959 , p. 395 , pl. 55, figs. 1-5, text fig. 1 ; Longacre, 1970 , p. 56, pl. 6, figs. 4, 5; Stitt, 1971, p. 21, pl. 7, fig. 10.

Material available.-One cranidium from locality $\mathrm{H}-1$.

Description of Whitehall material.-Cranidium subrectangular in outline, strongly convex sagittally. Glabella parallel sided, strongly convex sagittally and transversely, basal width 0.85 length, length 0.7 cranidial length (excluding occipital ring). Axial glabellar furrows deep, anterior glabellar furrow less deep, convex anteriorly. Two pairs lateral glabellar furrows. S1 deep, straight, short, oblique backwards. S2 deep, pitlike. Occipital ring simple, straight. Occipital furrow deep, straight, bent forward laterally. Frontal area convex, strongly downsloping, length (sagittal (sag.)) 0.3 cranidial length. Anterior border convex, length (sag.) 0.4 preglabellar field length, well defined by deep anterior border furrow. Anterior fixigena downsloping to near vertical anterolaterally. Interocular fixigena upsloping from axial glabellar furrow. Posterior fixigena not preserved. Eye ridge well developed, curved slightly backward toward palpebral lobe, abutts glabella anterior to S2. Palpebral lobes poorly preserved, slightly raised, centered opposite S2 (?). Preocular facial sutures strongly divergent, directed downward anterolaterally to near vertical. Postocular facial sutures not preserved.

Prosopon consists of scattered coarse perforate granules on the raised parts of the glabella, fixigenae, anterior border, and occipital lobe; closely spaced fine granules on the raised parts of the glabella, fixigenae, anterior border, and occipital lobe; and closely spaced fine pits on the anterior fixigenae and preglabellar field.

Discussion.-Rasetti (1959) originally described Bowmania pennsylvanica from cranidia collected at the type locality ("cca") in the Conococheague Limestone, Franklin County, Pa. He also tentatively assigned some forms to the taxon from near Frederick, Md. Rasetti designated a holotype and two paratype cranidia for $B$. pennsylvanica. Examination of the types shows that the preglabellar-field prosopon of the paratypes differs from that of the holotype. The holotype cranidium (Rasetti, 1959, pl. 55, figs. 1-3) is $4.6 \mathrm{~mm}$ long (sag.) and has evenly spaced scattered coarse granules and interspersed closely spaced fine granules on the preglabellar field. Paratype 
cranidia (Rasetti, 1959, pl. 55, figs. 4, 5) are 3.9 and $2.9 \mathrm{~mm}$ long (sag.). Prosopon of the preglabellar fields of the two paratypes is similar to that of the holotype except for the presence of abundant pits interspersed among the fine granules. The cranidium from the Whitehall Formation is $3.5 \mathrm{~mm}$ long (sag.) and intermediate in size between the two paratypes, and prosopon is similar to both paratypes. Therefore, the Whitehall cranidium is here considered conspecific with the paratypes. However, whether these forms are conspecific with the holotype cannot be proved without additional data. The fact that the nonpitted holotype is larger than the pitted forms suggests that late ontogenetic morphological changes may be a factor in explaining the differences. However, the available sample is too small to rule out the alternative possibility that two species are present in the type collection. The Whitehall cranidium is only tentatively assigned to Bowmania pennsylvanica for this reason.

Bowmania pennsylvanica was reported by Longacre (1970) from the Saukiella serotina Subzone in the Wilberns Formation of central Texas. The Texas forms differ in possessing glabellae that are slightly expanded anteriorly. However, presence or absence of pits on the anterior part of the cranidium was not mentioned by Longacre.

Stitt (1971) reported $B$. pennsylvanica from the lower part of the Signal Mountain Formation in south-central Oklahoma. The taxon ranges through the Saukia Zone in that area (Stitt, 1971, p. 22). Stitt also noted that some specimens have "pits scattered around the granules" but the feature was not discussed in detail.

Occurrence.-Saukiella serotina Subzone at locality H-1, lower Whitehall Formation, Washington County, N.Y.

Family MISSISQUOIIDAE Hupe, 1953

Genus MISSISQUOIA Shaw, 1951

Missisquoia Shaw, 1951, p. 108; Winston and Nicholls, 1967, p. 88.

Type species.-Missisquoia typicalis Shaw, 1951, by original designation.

Diagnosis.-The diagnosis provided by Winston and Nicholls (1967) is followed here.

Discussion-Missisquoia is a widespread genus in North America. The taxon is known from the Missisquoia Zone of Vermont (Shaw, 1951), New York (this report), Oklahoma (Stitt, 1971), Texas (Winston and Nicholls, 1967), Utah and Nevada (Taylor, 1971), Wyoming (U.S. Geol. Survey, unpub. data,
1953), and Alberta (Derby and others, 1972).

Genera closely similar to Missisquoia are unknown in North America. However, Parakoldinioidia Resser and Endo (Endo and Resser, 1937, p. 329, pl. 71, figs. 17-23), based on P. typicalis Resser and Endo from the Upper Cambrian of Manchuria, has some similarities. Both forms possess a more or less parallel sided to slightly expanding glabella with short lateral glabellar furrows and a distinct anterior glabellar notch. The similarity seems to be greatest between Missisquoia depressa Stitt (1971, pl. 8, fig. 5,6) and Parakoldinioidia typicalis (see Kobayashi, 1956, pl. 2, fig. 10-13). Both have bifid S1 lateral glabellar furrows. Also, the small size of the exoskeleton and position of the palpebral lobes is similar in both species. The principal differences between the two forms are the strongly convergent preocular facial suture across the anterior border in Parakoldinioidia and the parallel preocular sutures in Missisquoia. Whether the similarities represent close relationship or homeomorphy is unknown at present.

\section{Missisquoia typicalis Shaw \\ Plate 3, figures 1-9}

Missisquoia typicalis Shaw, 1951, p. 108, 109, pl. 23, figs. 1-10; Winston and Nicholls, 1967, p. 88, 89, pl. 13, figs. 2 ?, $5,6,10,12,15,18$; Stitt, 1971, p. 26, pl. 8 , figs. 1-4.

Material available.-Thirty cranidia, four librigenae, and 52 pygidia from locality $470 b_{1} ; 45$ cranidia, six librigenae, and 47 pygidia from locality 7098-CO ; 59 cranidia, 25 librigenae, and 123 pygidia from locality 7099-CO; and, two cranidia and one pygidium all questionably assigned from locality $\mathrm{H}-2$.

Description of Whitehall material.-Exoskeleton oval in outline, moderately convex, probably about one-half $\mathrm{cm}$ long. Cranidium subquadrate, moderately convex. Glabella variable, slightly tapered to slightly expanded anteriorly, basal width 0.7 to 0.8 length (sag.), anterior lobe with medial notch. Axial glabellar furrows well defined, anteriorly confluent with anterior border furrow. Lateral glabellar furrows pitlike on sides of glabella. S1 convex, deeply impressed, connected to axial glabellar furrow. S2 transverse, straight, deeply impressed, connected to axial glabellar furrow. S3 transverse, straight, faintly impressed, not connected to axial glabellar furrow. S4 faint or absent, straight, connected to axial glabellar furrow. Occipital ring simple, rounded posteriorly. Occipital furrow deep, straight. Medial region of occipital ring with node or short 
spine in small individuals, node may or may not be present in large individuals. Preglabellar field absent. Anterior border horizontal, flat, length (sag.) about 0.1 cranidial length. Anterior margin evenly rounded. Anterior fixigena evenly downsloping anterolaterally. Interocular fixigena (including palpebral lobe) convex, raised about one-half glabellar height, width (tr.) about 0.5 adjacent glabellar width. Posterior fixigena subtriangular, downsloping laterally, about equal in width (tr.) to occipital ring. Posterior border furrow not connected to occipital furrow. Eye ridge faintly developed to absent, abuts axial glabellar furrow opposite S3 where observable. Palpebral lobe rounded, subhorizontal, not differentiated from interocular fixigena by palpebral furrow, length (exsag.) 0.3 to 0.4 glabellar length (sag.), centered opposite S2. Preocular facial sutures parallel, straight, downsloping anteriorly at about $30^{\circ}$ angle from horizontal. Postocular facial sutures divergent, convex.

Librigena narrow, evenly rounded laterally. Genal field convex, downsloping laterally to deep border furrow, genal field continuous with genal spine posterolaterally through genal corner. Ocular incisure with raised eye socle and holochroal visual surface often attached. Eye socle about 0.5 height of visual surface. Lateral border horizontal, flat, differentiated from genal field by abrupt change in slope. Genal spine broken on all observed specimens.

Thorax unknown.

Pygidium variable, strongly convex to moderately convex, subtriangular in outline, length about 0.8 width. Axis straight sided, tapered posteriorly, nine axial rings plus terminal piece. Axial rings become faintly defined posteriorly. Pleural regions flat, strongly downsloping to near vertical at margin, five pairs deeply impressed interpleural furrows, six pairs less deeply impressed pleural furrows. Pleurae terminate distally into apparent blunt spines.

Prosopon consists of fine closely spaced granules on the glabella, fixigena, genal field, and pygidium and occasional scattered larger granules. The borders of the cranidium and librigena have longitudinal terrace lines.

Discussion.-Samples from the Whitehall Formation are morphologically variable in degree of taper of glabella, convexity of pygidium, and relative abundance of large scattered granules on dorsal surfaces.

The type material from the Highgate Formation near Highgate Falls, Vt. (Shaw, 1951, 1955, 1958), has similar variability, although some diastrophic distortion seems to have modified the Vermont material. Comparison of New York specimens with undistorted topotypic collections from the Highgate suggests that the forms are conspecific.

Winston and Nicholls (1967) assigned material from the Wilberns Formation of central Texas to $M$. typicalis. The Texas material is similar to the New York specimens except for the attributed librigena (Winston and Nicholls, 1967, pl. 13, fig. 2). The Texas librigena is equidimensional, with a short (tr.) posterior margin, and slender incurved genal spine. Such shape contrasts markedly with librigenae here attributed to $M$. typicalis from New York. The New York form is rather long and slender and lacks a posterior border furrow. The otherwise strong similarity between cranidia and pygidia from Texas and New York suggest that the librigena illustrated by Winston and Nicholls may have been attributed in error and should be reevaluated.

Stitt (1971) attributed material from the upper part of the Signal Mountain Limestone of southcentral Oklahoma to $M$. typicalis. The specimens illustrated by Stitt seem to fall within the range of variation of the New York material.

Missisquoia typicalis occurs in the upper part of the Notch Peak Limestone of west-central Utah (Taylor, 1971). The Utah collections contain a greater proportion of individuals with slightly expanded glabella than do the New York collections. However, taxonomic significance of this difference is presently unknown as both collections are highly variable in this feature.

Occurrence.-Missisquoia Zone localities $470 \mathrm{~b}_{1}$, 7098-CO, 7099-CO, and H-2(?) from the upper Whitehall Formation, Washington County, N.Y.

Family PLETHOPELTIDAE Raymond, 1925

Genus PLETHOMETOPUS Ulrich, 1931

Plethometopus Ulrich in Bridge, 1931, p. 221

Type species.-Bathyurus armatus Billings, 1860, by original designation.

Discussion.-Morphological characteristics of the genus have been summarized in Harrington and others $(1959$, p. O410). Plethometopus is distinguished from other members of the Plethopeltidae by the presence of at least four of the following five features: a triangular-shaped occipital region, occipital furrow, effaced preglabellar furrow, faint to absent posterior axial glabellar furrows, and posterior border furrows. 
Plethometopus obtusus Rasetti

Plate 1, figures 11-14

Plethometopus obtusus Rasetti, 1945, p. 472, pl. 62, figs. 1, 2; Rasetti, 1959, p. 383 pl. 53, figs. 11-14; Longacre, 1970 , p. 19 , pl. 6 , figs. 14 , 15; Stitt, 1971 , p. 35 ; pl. 6, fig. 16.

Unassigned pygidium no. 7 , Rasetti, 1945 , p. 477 , pl. 62 , figs. 2930.

Plethometopus modestus Ulrich. Winston and Nicholls, 1967, p. 87, pl. 10, fig. 11 .

Material available.-Eight fragmentary cranidia from locality $473 \mathrm{f}$.

Diagnosis.-A species of Plethometopus with palpebral lobes centered anterior to the cranidial midline; axial glabellar furrows only present opposite and posterior to the palpebral areas; slightly divergent preocular facial sutures; subtriangularshaped occipital lobe that lacks an occipital spine; and a deeply impressed, posteriorly concave occipital furrow.

Description of Whitehall material.-Cranidium subrectangular in outline, width (tr. between palpebral lobes) approximately 0.8 length (sag.), sagittally convex. Glabella undifferentiated except occipital region. Axial glabellar furrows consist of shallow depressions extending from posterior border to a position opposite palpebral lobes. Axial furrows absent anteriorly. Lateral glabellar furrows absent. Occipital ring simple, subtriangular in outline, well defined by occipital furrow. Occipital furrow deep, slightly concave posteriorly. Frontal area evenly downsloping at about $45^{\circ}$ angle from horizontal, continuous with glabellar region. Anterior border absent. Posterior fixigena short (tr.), width (tr.) about 0.3 basal glabellar width, triangular shaped, deep border furrow present. Anterior fixigena undifferentiated. Palpebral lobes consist of narrow (tr.) raised ridges, length (exsag.) 0.2 cranidial length (excluding occipital lobe), centered slightly anterior to cranidial midpoint. Preocular facial sutures slightly divergent, downsloping. Postocular facial sutures strongly divergent, convex.

Exoskeletal surfaces and internal molds are smooth. Librigena, thorax, and pygidium are unknown in Whitehall collections.

Discussion.-Plethometopus obtusus was originally described by Rasetti (1945) from Boulder 57 at Lévis, Quebec. Later, Rasetti (1959) recorded the species from the Conococheague Limestone of Washington County, Md., and attributed pygidia from Lévis that had previously (Rasetti, 1945) been illustrated but unassigned.
Lochman (1946, p. 551, pl. 1, figs. 7-9) described and illustrated Plethometopus knop $f$ from weathered dolomite 11/4 miles south of Pine Plains, Dutchess County, N.Y. The holotype illustrated by Lochman (fig. 9) is similar to material from Whitehall except that the cranidium is more quadrate in outline. The ratio of cranidial width (measured transversely between distal margins of palpebral lobes) to cranidial length is approximately 1.0 in $P$. knopfi and 0.8 in Whitehall material attributed to $P$. obtusus.

Longacre (1970) established the presence of $P$. obtusus in the Wilberns Formation of central Texas where she assigned occurrences of the species to the Saukiella serotina and Corbinia apopsis Subzones. The Wilberns material previously assigned to Plethometopus modestus Ulrich by Winston and Nicholls (1967) was reassigned to P. obtusus by Longacre (1970).

Stitt (1971) collected $P$. obtusus from the Signal Mountain Formation of south-central Oklahoma where he assigned its occurrences to the Saukiella serotina and Corbinia apopsis Subzones.

Search of the USNM collections yielded a single cranidium from New Jersey which can be tentatively assigned to $P$. obtusus. The locality is listed as number 11c, which Walcott (1912a, p. 178) described as follows: "Upper Cambrian: Hardyston quartzite ***, O'Donnell and McManniman's quarry, Newton, Sussex County, N.J." Later, Walcott (1914, p. 389) emended the stratigraphic designation to "Kittatinny limestone." The specimen occurs as an internal mold in fine-grained dolomitic sandstone. The cranidium is well enough preserved to show the divergent preocular facial sutures, subtriangular-shaped occipital lobe, and incomplete axial glabellar furrows which are characteristic of the species.

Occurrence.-Saukiella serotina Subzone, locality 473f, Washington County, N.Y.

\footnotetext{
Plethometopus sp. A

Plate 1, figures 15-17
}

Material available.-One cranidium from locality $473 \mathrm{f}$.

Description.-Cranidium subtrapezoidal in outline, strongly convex sagittally, length 0.9 width. Glabella undifferentiated. Axial glabellar furrows faint, only present on posterior one-fourth of cranidium. Occipital ring undifferentiated. Frontal area downsloping at about $60^{\circ}$ angle from the horizontal. Anterior fixigena undifferentiated. Posterior fixigenae triangular, width (tr.) 0.3 basal glabellar width. Posterior border furrow shallow, pitlike. 
Palpebral lobes consist of raised ridges, length (exsag.) 0.2 cranidial length, centered anterior to cranidial midline (0.4 cranidial length). Preocular facial sutures strongly convergent, forming bluntly pointed anterior cranidial margin. Postocular facial sutures strongly divergent, convex.

Exoskeletal and internal mold surfaces smooth except for bertillion prosopon on the posteriormost part of the occipital region.

Discussion.-The single cranidium is similar to forms assigned to both Stenopilus and Plethometopus. The former usually have strongly convergent preocular facial sutures, narrow palpebral lobes, absence of dorsal furrows, and coalescence of the occipital region with the basal glabellar lobe. In contrast, species assigned to Plethometopus usually have slightly divergent to subparallel preocular facial sutures, narrow palpebral lobes, axial glabellar furrows in varying degrees of completeness, and usually a differentiated occipital region. An exception is Plethometopus convergens (Raymond) which possesses slightly convergent preocular facial sutures. However, Plethometopus sp. A differs from $P$. convergens in having more strongly convergent preocular facial sutures and palpebral lobes which are centered anterior, rather than posterior, to the cranidial midline. (See also Rasetti, 1959, pl. 53, figs. 15, 16 ; Longacre, 1970 , p. 19.)

Morphologically, the cranidium of Plethometopus sp. A is intermediate between Plethometopus and Stenopilus. However, the subtle differences point up the arbitrary and highly subjective distinction between these genera when only their cranidia are considered. This situation should serve as a cautioning influence in applying too much emphasis on biostratigraphic correlations when only fragmentary smooth trilobites are available.

Occurrence.-Plethometopus sp. A by association is assigned to the Saukiella serotina Subzone, at locality 473f, Washington County, N.Y.

\section{Genus PLETHOPELTIS Raymond, 1913}

Plethopeltis Raymond, 1913, p. 64; Field, 1915, p. 37; Ulrich in Bridge, 1931 p. 219; Bridge and Cloud, 1947, p. 556; Longacre, 1970, p. 19.

Type species.-Agraulos saratogensis Walcott, 1890 , by original designation.

Discussion.-Plethopeltis was originally based on material from the Hoyt quarry (Walcott's locality 76), 4 miles west of Saratoga Springs, N.Y. Longacre $(1970$, p. 19-21) recently discussed the complex nomenclatural history of the genus and the type col- lection upon which it was based. She provided a diagnosis and concluded that Plethopeltis can be distinguished from other genera of the Plethopeltidae by the presence of complete axial and preglabellar furrows and lack of an anterior border furrow. These features distinguish Plethopeltis from the similar genus Plethometopus Ulrich.

\author{
Plethopeltis sp. indet. \\ Plate 1, figures 1-3
}

Discussion.-Locality H-3 from the Whitehall Formation contains five poorly preserved cranidia which conform to the concept of Plethopeltis. The forms have well-defined axial furrows, shallow preglabellar furrows, and lack lateral glabellar furrows. Axial furrows are straight to slightly concave laterally. Occipital lobes are triangular in outline and well defined by a simple, slightly convex occipital furrow. Four of the internal cranidial molds retain sufficient exoskeletal material to show that prosopon consists of evenly spaced granules on three cranidia and a smooth surface on the fourth specimen. Surfaces of well-preserved internal molds are finely pitted. No pygidium is known from the sample.

Granular prosopon has been reported on several forms assigned to Plethopeltis. They include: Plethopeltis granulosa Resser, 1942, from New York; Plethopeltis arbucklensis Stitt, 1971, from southcentral Oklahoma; and, Plethopeltis sp. of Longacre (1970) from central Texas. Plethopeltis granulosa was based on part of Walcott's hypodigm of Agraulos saratogensis from locality 76 at the Hoyt quarry, 4 miles west of Saratoga Springs, N.Y. It differs from the Whitehall material in having lateral glabellar furrows, more deeply impressed axial and anterior glabellar furrows, and more closely spaced granules.

Plethopeltis arbucklensis Stitt differs from the Whitehall specimens in having laterally convex axial glabellar furrows and a more strongly tapered glabella.

Plethopeltis sp. of Longacre (1970) from the Saukiella pyrene Subzone of central Texas seems similar to the Whitehall specimens. An apparent difference is the presence of axial glabellar furrows which are slightly convex laterally in the Texas material. The apparent similarity between New York and Texas specimens may be a result of the few features available for comparison. Because of this possibility and the fact that Plethopeltis seems to range throughout the Trempealeauan Stage, caution should probably be exercised in making biostratigraphic inferences 
from material assigned to Plethopeltis unless all morphologic parts are present and taxa can be more precisely characterized than can be done on cranidial features alone.

Occurrence.-Saukiella serotina Subzone, locality $\mathrm{H}-3$, lower Whitehall Formation, Washington County, N.Y.

\section{Family PTYCHASPIDIDAE Raymond, 1924 \\ Subfamily PTYCHASPIDINAE Longacre, 1970 \\ Genus EUPTYCHASPIS Ulrich, 1931}

Euptychapsis Ulrich in Bridge, 1931, p. 217; Winston and Nicholls, 1967 p. 78 ; Longacre, 1970, p. 40.

Type species.-Euptychaspis typicalis Ulrich in Bridge, 1931, by original designation.

Discussion.-The generic concept given by Longacre (1970) is followed here. Information on the previously undescribed pygidium of $E$. typicalis is added under the description of new material below.

\section{Euptychaspis typicalis Ulrich \\ Plate 2, figures 4-11}

Euptychaspis typicalis Ulrich in Bridge, 1931, p. 218, pl. 19, figs. 5-7; Dake and Bridge, 1932, p. 740, pl. 12, fig. 3; Rasetti, 1959, p. 393, pl. 52, figs. 11-13; Winston and Nicholls, 1967, p. 78, pl. 9, fig. 17; Longacre, 1970, p. 42 , pl. 4, fig. 9 ; Stitt, 1971, p. 42 , pl. 6 , fig. 19 .

Material available.-Nine cranidia, nine librigenae, and three pygidia from locality $\mathrm{H}-1 ; 15$ cranidia and two librigena from locality $\mathrm{H}-3$; and one cranidium tentatively assigned from locality $473 f$.

Description of Whitehall material.-Cephalon semicircular in outline, strongly convex. Glabella subparallel sided to expanded forward, basal width 0.85 length. Axial glabellar furrows deep, broad; anterior furrow shallow. Lateral glabellar furrows well developed, deep. S1 and S2 continuous across glabella forming straplike L1 and L2. S3 faintly impressed rarely on internal molds. Occipital ring drawnout into broad blunt spine. Occipital spine triangular in cross section, inclined at approximately $45^{\circ}$ to horizontal. Frontal area downsloping, nearly vertical, length (sag.) 0.1 glabellar length. Preglabellar field absent. Anterior border wirelike or absent. Anterior fixigenae not differentiated, continuously curved laterally from frontal area. Interocular fixigenae upsloping, width (tr.) 0.7 adjacent glabellar width. Posterior fixigenae approximately equal to occipital ring width (tr.) Eye ridge moderately developed on dorsum, strongly developed on internal molds, abutts axial glabellar furrow at L3. Palpebral lobes poorly preserved, apparently raised above level of fixigenae, length (exsag.) 0.3 glabellar length, centered opposite L2. Palpebral furrow deep, arcuate, concave abaxially. Preocular facial sutures convergent, convex. Postocular facial sutures weakly divergent, slightly convex.

Librigenae long, narrow, steeply downturned laterally. Genal field downsloping continuously to lateral margin, anteriorly confluent with frontal area, posteriorly confluent with genal spine. Ocular incisure with raised eye socle and attached (?) visual surface. Posterior border deeply impressed adaxially from genal spine. Lateral border furrow faintly impressed. Genal spine long, length about twice cranidial length, triangular in cross section, distally curved slightly downward below level of cranidium.

Thorax unknown.

Pygidium subelliptical in outline, length 0.7 width. Axis tapered posteriorly, length about 0.6 pygidial length (sag.), two axial rings plus terminal piece. Pleural regions diminutive, separated from wide border by ridge. Border downsloping, lower than pleural regions.

Prosopon consists of reticulate pattern of ridges on the cranidial dorsum and heavy anastomosing terrace lines on the frontal area and lateral parts of the librigenae. Internal molds finely pitted. Pygidial surfaces poorly preserved, border region with scattered pits which may be fortuitous.

Discussion.-Longacre $(1970$, p. 42) noted that cranidia assigned to $E$. typicalis from central Texas possess a narrow (sag.) anterior border. A narrow anterior border is present on some, but not all, specimens from New York and one of Ulrich's syntypes (USNM 83493) from Missouri. This feature, in association with relatively wide fixigenae and an anterior glabellar lobe that does not reach the anterior margin, distinguishes $E$. typicalis from other nominal species assigned to the genus.

The pygidium, described here for the first time, has a border markedly depressed below the level of the axis and pleural regions. This construction probably facilitated enrollment by providing a notch for abutment between the ventral doublure-rostral region of the cephalon and the pygidial dorsum.

Euptychaspis typicalis is known from the Saukia Zone of southern Missouri (Ulrich, 1930) and Maryland (Rasetti, 1959); the Saukiella junia Subzone of central Texas (Winston and Nicholls, 1967; Longacre, 1970); and the Saukiella junia and Saukiella serotina Subzones of Oklahoma (Stitt, 1971) and east-central Nevada (Taylor, 1971).

Occurrence.-Saukiella serotina Subzone, localities $\mathrm{H}-1, \mathrm{H}-3$, and tentatively $473 \mathrm{f}$, lower Whitehall Formation, Washington County, N.Y. 
Subfamily SAUKIINAE Ulrich and Resser, 1933

Discussion.-Ulrich and Resser $(1930,1933)$ published two monographs on the Upper Mississippi Valley representatives of the Dikelocephalidae, which included subfamilies Dikelocephalinae and Osceolinae (1930) and Saukiinae (1933). General impracticability of Ulrich and Resser's treatment of the dikelocephalid genera and species led Raasch (1951) to a restudy of the fossil groups and establishment of many species synonomies. Raasch (1951, p. 139) pointed out that among several difficulties with the Ulrich and Resser systematics is that the authors based some taxa on misattributed exoskeletal parts which originated from different localities and in some cases different stratigraphic horizons. Unfortunately, Raasch's study did not include nomenclatural stabilization of the type collections or revised diagnoses of the dikelocephalid genera.

The taxonomic procedure followed by Ulrich and Resser created a critical problem in that many type species were based on numerous specimens in "cotype series." This results in difficulty in comparing new material with type collections because attributed specimens in the type collections are suspect at best and biologically meaningless at the worst. Because of the taxonomic procedures used by Ulrich and Resser $(1930,1933)$, objectively based concepts of the dikelocephalid genera cannot be established at present without a comprehensive reevaluation of their type species. Pending such a reevaluation I have chosen to apply the saukiinid generic names reservedly, in recognition of the possibility that they may not represent natural groupings of species and that the type collections may contain nonconspecific attributions of exoskeletal parts. The genera that are affected in this study are Calvinella Walcott and Prosaukia Ulrich and Resser.

\section{Genus CALVINELla Walcott, 1914}

Calvinella Walcott, 1914, p. 388; Ulrich and Resser, 1933, p. 215; Lochman, in Harrington and others, 1959, p. O323; Longacre, 1970 , p. 45.

Type species.-Dikelocephalus spiniger Hall, 1863, by original designation.

Discussion.-Longacre (1970) has most recently summarized the morphological features of species assigned to Calvinella. She characterized the pygidium as transversely elliptical. However, Ulrich and Resser (1933, pl. 38, 39) included several forms with subcircular pygidia.

Features normally used to distinguish Calvinella from other genera of the Saukiinae include unequal- ly divided pygidial pleural fields, presence of an occipital spine, and granular prosopon on the cranidium. These differences are all of doubtful taxonomic significance because species have been included in Tellerina that have unequally divided pleural regions; Prosaukia includes species with occipital spines, and Calvinella includes forms with bertillion, granular, or mixtures of both kinds of prosopon on cranidia. Problems relating to the artificiality of Calvinella and other saukiinids is discussed under the heading "Subfamily Saukiinae."

"Calvinella" prethoparia Longacre

Plate 2, figures 1-3

Calvinella prethoparia Longacre, 1970 , p. 45, pl. 6, figs. 712.

Material available.-Three cranidia and one librigena from locality $\mathrm{H}-1$; five cranidia, and one librigena questionably assigned from locality $\mathrm{H}-3$.

Description of Whitehall material.-Cranidium subtrapezoidal in outline, moderately convex. Glabella subparallel sided to slightly tapered forward, length (excluding occipital ring) approximately 0.9 basal glabellar width, anteriorly truncate. Axial glabellar furrows wide, deeply impressed. Anterior glabellar furrow less deeply impressed than axial furrows. Four pairs lateral glabellar furrows. S1 deeply impressed laterally, faintly geniculate, becoming shallower adaxially, connected to axial furrow, connected across midline. S2 straight, oblique backwards, deeply impressed laterally, becoming faintly connected across midline, connected to axial furrow. S3 shallow, straight, transverse, not connected to axial furrow. S4 shallow, straight, oblique forward, connected to axial furrow. Occipital ring simple, concave forward, with occipital spine (length not observed). Occipital furrow concave forward, deeply impressed laterally, moderately impressed adaxially. Preglabellar field concave, consisting of a broadening of the anterior glabellar furrow. Anterior border width (sag.) approximately 0.2 cranidial length, convex. Anterior border furrow deep, well differentiated abaxially, becoming shallower adaxially and inosculating with anterior glabellar furrow. Anterior fixigena gently downsloping anterolaterally. Interocular fixigena width (tr.) $\mathbf{0 . 5}$ adjacent glabellar width, raised above level of axial glabellar furrow, below level of glabellar crest, subhorizontal. Postocular fixigena triangular in outline, width (tr.) approximately 0.8 occipital lobe width. Posterior border furrow deep, straight, offset posteriorly from occipital furrow. Eye ridge 
absent. Palpebral lobe lunate, flat, below level of interocular fixigena, length (exsag.) 0.5 glabellar length, centered anterior to glabellar midpoint opposite anterior part of L2. Anterior end palpebral lobes opposite S4, posterior end opposite S1. Preocular facial sutures subparallel to anterior border, converging diagonally across anterior border to midline. Postocular facial sutures divergent, straight.

Librigena narrow, margin evenly rounded. Genal field gently convex, well differentiated from raised lateral and posterior borders by deep marginal furrows. Lateral border furrow and posterior border furrow confluent at corner angle, lateral furrow continuous, faintly impressed onto genal spine. Genal spine approximately two-thirds librigenal length (exsag.) Inner spine angle approximately $90^{\circ}$.

Thorax and pygidium unknown.

Prosopon consists of anastomosing ridges on the cranidium except in furrows which are smooth. Large cranidia (approx $8 \mathrm{~mm}$ long) have ridges grading to granules with irregularly shaped bases on the adaxial part of the glabella and occipital ring. Smaller cranidia (approx $4 \mathrm{~mm}$ long) lack granules, and the anastomosing ridges cover the entire dorsal surface. The only librigena attributed with certainty has faint anastomosing ridges on the genal field and lateral border. Weak development of ridges on the librigena may result from poor preservation.

Discussion.- "Calvinella" prethoparia Longacre was originally described from the Saukiella serotina Subzone of the Wilberns Formation of central Texas. Cranidia from the Whitehall Formation attributed to the species differ from the Texas material in possessing granular prosopon which is more adaxially restricted and absent from the anterior border. This difference is not considered of taxonomic significance.

The holotype of $C$. prethoparia (see Longacre, 1970, pl. 6, fig. 7) is an internal mold having S2 furrows that connect across the midline. The depth of impression of S2 is greater on the holotype than on the New York material. This character-state may be related to instar size because smaller cranidia tend to have more weakly developed S2 furrows than do larger cranidia. The holotype is more than twice as long as the largest cranidium illustrated here.

"Calvinella" prethoparia differs considerably from material attributed to Calvinella spiniger (Hall), the type species of Calvinella. (See Ulrich and Resser, 1933, pl. 37, 38.) Major differences in cranidial structure in "C." prethoparia include: parallel rather than divergent preocular facial sutures; wide, flat, interocular fixigenae rather than narrow, abaxially upsloping fixigenae; triangular posterior fixigenae, rather than subparallel sided; and relatively short (exsag.) palpebral lobes that are centered anterior to the glabellar midpoint opposite L2, rather than long palpebral lobes that center behind the glabellar midpoint opposite $\mathrm{S} 1$. This combination of differences is sufficient to establish a new genus of Saukiinae based on Calvinella prethoparia Longacre. However, such action is held in abeyance pending a comprehensive reevaluation of the existing saukiinid genera.

Occurrence.-Saukiella serotina Subzone at localities $\mathrm{H}-1$ and $\mathrm{H}-3$, lower Whitehall Formation, Washington County, N.Y.

\section{Genus PROSAUKIA Ulrich and Resser, 1933}

Prosaukia Ulrich and Resser, 1933, p. 137; Lochman, in Harrington and others, 1959, p. O324; Longacre, 1970, p. 47.

Type species.-Dikelocephalus misa Hall, 1863, by original designation.

Discussion.-The original diagnosis of Prosaukia given by Ulrich and Resser (1933) provided few features that are not also characteristic of the other genera of the Saukiinae. Lochman (in Harrington and others, 1959) gave an improved diagnosis, which was later slightly modified by Longacre (1970). In summary, Prosaukia has been distinguished by the presence of an anteriorly tapering glabella, convex preglabellar field, an anterior border furrow that shallows transversely across the midline, and librigenae with lateral and posterior border furrows that are not confluent and extend subparallel distally along the genal spine. Forms have been included in the genus which have prosopon described or illustrated as smooth, granular, or consisting of anastomosing ridges.

Species have been assigned to Prosaukia that show exceptions to the characteristics normally used to differentiate the genus. For example, Prosaukia curvicostata Ulrich and Resser, 1933, possesses a parallel-sided, anteriorly rounded glabella and an anterior border furrow that is evenly impressed across the midline. In addition, most species assigned to Prosaukia have librigenae with nonconfuent border furrows. At least one exception is Prosaukia delecostata Ulrich and Resser (1933, pl. 26, fig. 15) in which the furrows are confluent. General problems related to the artificiality of the saukiinid genera are discussed under the heading "Subfamily Saukiinae." 
"Prosaukia" spinula Taylor, n. sp.

Plate 2, figures 15-20

Types.-Holotype cranidium, USNM 186598; paratype cranidia, USNM 186599 and 186600 ; paratype librigena, USNM 186602; paratype pygidium, USNM 186603, all from locality $\mathrm{H}-1$. Paratype pygidium, USNM 186601 from locality H-3. All type specimens are from the lower Whitehall Formation, Washington County, N.Y.

Material available.-Ten cranidia, 15 librigenae, and three pygidia from locality $\mathrm{H}-1 ; 10$ cranidia, six librigenae, and six pygidia from locality $\mathrm{H}-3$; 13 cranidia, seven librigenae, and three pygidia from locality $470 \mathrm{~b}$; and three librigenae and one pygidium questionably assigned from locality $473 \mathrm{f}$.

Diagnosis.-A species of saukiinid trilobite with a pygidium having a single short posteriorly directed median marginal spine, an axis greater than onehalf of the pygidial length and a glabella with bertillion pattern prosopon.

Description.-Cranidium subrectangular in outline, moderately convex. Glabella trapezoidal in outline, anteriorly truncate, length approximately equal to basal width; sides straight, slightly tapered anteriorly from L1; L1 bowed outward slightly. Axial furrows well defined, deeply impressed. Anterior glabellar furrow shallower at midline than at anterolateral corners of glabella. Two pairs lateral glabellar furrows. S1 concave, deeply impressed laterally, becomes faintly impressed adaxially, faintly connected across midline on small holaspids, not connected on large holaspids, may connect on internal molds of large holaspids. S2 straight, faintly impressed laterally, not connected across midline. Occipital ring simple, straight, with medial node. Occipital furrow curved forward slightly at midline. Frontal area length (sag.) 0.2 cranidial length, subhorizontal. Anterior border slightly raised, poorly differentiated by shallow anterior border furrow. Preglabellar field convex, length (sag.) about 0.5 anterior border length (sag.). Anterior fixigena evenly downsloping. Interocular fixigena gently upsloping laterally, width (tr.) 0.3 adjacent glabellar width. Posterior fixigena relatively short (tr.), subparallel sided. Eye ridge absent. Palpebral lobes lunate, length (exsag.) 0.7 glabellar length, flat, subhorizontal, below level of interocular fixigena, centered posterior to glabellar midpoint opposite S1. Preocular facial sutures weakly divergent to anterior border furrow, becoming strongly convergent and coursing diagonally across anterior border to mid- line. Postocular facial sutures divergent, sinuous.

Librigena moderately convex, evenly rounded laterally. Genal field convex, well differentiated from lateral border by deep furrow. Lateral border raised, convex, continuous with long (?) genal spine. Lateral and posterior border furrows deeply impressed, connected at corner angle, lateral furrow continuous distally onto genal spine. Inner spine angle about $135^{\circ}$.

Thorax unknown.

Pygidium subcircular in outline, length about 0.9 width, strongly convex transversely. Axis tapered, straight sided, length about 0.7 pygidial length, four axial rings plus terminal piece, posteriormost ring poorly differentiated. Pleural fields strongly downsloping laterally, subequally divided by five furrows and ridges, furrows strongly backturned. Pleural fields change slope distally to form poorly differentiated gently downsloping border. Posterior margin of pygidium drawn out posteriorly into broadly pointed spine, length about 0.1 pygidial length, upturned slightly distally. Ventral doublure wide, reaching posterior end of axis (not observed anterolaterally).

Cranidial prosopon consists of bertillion pattern on the occipital ring and posterior part of glabella decreasing in degree of definition anteriorly, and faint bertillion pattern on the anterior fixigena. Other areas of cranidium smooth. Internal molds smooth.

Librigena with complex anastomosing ridges on genal field, lateral border, posterior border, and genal spine. Anastomosing ridges faint on internal molds.

Pygidium with anastomosing ridges on axis, pleural regions, and border oriented more or less parallel to margins. Internal molds of pygidium smooth.

Discussion.— "Prosaukia" spinula n. sp. is placed in "Prosaukia" because of the presence of a convex preglabellar field, a slightly forward-tapering glabella, and an anterior border furrow that shallows across the midline. The attributed librigenae are similar to forms usually assigned to Calvinella in possessing lateral and posterior border furrows that merge at the corner angle and continue on to the genal spine as an extension of the lateral furrow. Librigena assigned to "Prosaukia" usually have lateral and posterior border furrows that do not become confluent at the corner angle.

Rasetti (1946, p. 541, pl. 1, figs. 17-19) reviewed Saukia eboracensis Resser, 1942, on the basis of 
additional material collected from the type locality in the Hoyt Limestone, one mile northwest of Saratoga Springs, N.Y. He reassigned the species to Prosaukia on the basis of attributed cranidia which have convex preglabellar fields. The attributed cranidia are similar to those here assigned to "Prosaukia" spinula. Differences include adaxially disconnected, rather than connected, S2 furrows and weaker development of cranidial prosopon in " $P$." spinula. The greatest differences between the two species are shown by the attributed pygidia. The holotype pygidium of Prosaukia eboracensis is wider than long, possesses five axial rings rather than four, and lacks the strongly backturned pleural furrows and posterior marginal spine characteristic of "P." spinula.

Lochman (1946, p. 549, pl. 1, figs. 1-6) described and illustrated Prosaukia briarcliffensis from weathered dolomite outcropping 11/4, miles south of Pine Plains, Dutchess County, N.Y. The specimens, although fragmentary, are similar to material assigned to " $P$." spinula in possessing librigenae with anastomotic ridges on the genal field. The cranidium of $P$. briarcliffensis has $\mathrm{S} 1$ furrows that do not connect across the midline. However, the furrows are relatively deeply impressed laterally, as in " $P . "$ spinula, so that the faint connection of S1 furrows in " $P . "$ spinula may not be a significant difference. The pygidium attributed to $P$. briarcliffensis is similar to " $P$." spinula in having a circular outline, backturned pleural furrows, similar axial taper, and number of axial rings. Unfortunately the posterior part of the border region and margin is broken so that only the ventral doublure is preserved. The specimen is oriented in the matrix in such a way that presence or absence of a posterior spine cannot be determined. Allowing for uncertainties of preservation, the greatest apparent difference between "P." spinula and $P$. briarcliffensis is in the presence of bertillion prosopon on the glabella of the former and coarse granular prosopon on the glabella of the latter.

Cranidia assigned to " $P$." spinula are remarkably similar to the type cranidia of Saukiella serotina Longacre (1970, pl. 6, figs. 1-3). However, she did not illustrate a librigena or pygidium, so that critical comparison is not presently possible. Longacre (1970, p. 53) placed Saukiella norwalkensis of Winston and Nicholls (1967, pl. 11, figs. 6-8, 12) in synonomy with $S$. serotina. The librigena illustrated by Winston and Nicholls (fig. 7) is of the "typical Saukiella form" with a slightly advanced genal spine and deep confluent border furrows that do not extend onto the genal spine. The cranidia illustrated by Winston and Nicholls (figs. 6, 8) differ from those illustrated by Longacre in having more forwardtapering glabellae and relatively wider preglabellar fields. These observations lead to the question whether the librigena placed in synonomy with $S$. serotina is indeed correctly attributed. Because of this uncertainty, the relationship between " $P$." spinula and $S$. serotina cannot be satisfactorily resolved at present.

The pygidia and librigenae here attributed to "Prosaukia" spinula are most similar to Calvinella americana Kobayashi, 1935 [=Calvinella walcotti Ulrich and Resser, 1933; not Calvinella walcotti (Mansuy, 1915) ] from the Upper Cambrian of Wisconsin. (See Ulrich and Resser, 1933, pl. 40, figs. 1-14.) The pygidium attributed to $C$. americana is subcircular in outline with the posteriormost part of the margin upturned as in "P." spinula. In all available specimens of $C$. americana, the area occupied by the pygidial spine is broken away, and it cannot be definitely stated that it was originally present. However, fossil preservation is such in the C. americana sample, that specimens split out of the matrix along partings parallel to the bedding. As the pygidial spine would have been upcurved it would tend to be in a higher plane than the main part of the pygidium, thus potentially becoming easily broken when the rock was split. In all specimens observed (for example, Ulrich and Resser, 1933, pl. 40, figs. $11-14,20)$ the region of the base of the pygidial spine appears roughened as if part was broken away. Because of these facts, I conclude that the pygidium of $C$. americana probably possessed a terminal spine.

The pygidium assigned to " $P$." spinula differs from $C$. americana in possessing more sharply backturned plaural furrows and an axial length to pygidial length ratio of less than 0.5 .

Librigenae attributed to $C$. americana by Ulrich and Resser (1933) are similar to forms here attributed to "P." spinula. Both have marginal furrows that become confluent at the corner angle and in which the lateral furrow continues undeflected on to the genal spine. The "cotype" librigena illustrated by Ulrich and Resser on their plate 40 , figure 9 , has prosopon preserved on the genal field which consists of anastomosing ridges, although this feature is not shown in their illustration. Such prosopon is virtually identical with that on the genal fields of librigenae here attributed to " $P$." spinula. 
In contrast to the librigena and pygidium, cranidia attributed to " $P$." spinula and $C$. americana are distinctly different. "Cotype" cranidia of $C$. americana all show a lack of a preglabellar field, presence of an evenly impressed anterior border furrow, and an occipital spine. Ulrich and Resser (1933, p. 236) described C. americana as "usually quite smooth, only rarely showing evidence of minute tuberculation." Examination of the type material shows that the specimens have been worn so much, probably since Ulrich and Resers' study, that original prosopon cannot be verified with certainty. The cranidium illustrated by Ulrich and Resser on their plate 40 , figure 1 , seems to show a granular prosopon. In contrast, cranidia assigned to " $P$." spinula have convex preglabellar fields, adaxially shallowing anterior border furrows, and absence of occipital spines.

An argument could be made for assigning " $P$." spinula to Calvinella on the basis of morphological similarity to C. americana. However, I have chosen to place more taxonomic weight on features of the cranidium, the structure of which is most consistent with the tentative operational concept of Prosaukia.

Occurrence.-Saukiella serotina Subzone at localities H-1, H-3, 470b, and questionably 473f, from Washington County, N.Y.

\section{Family SOLENOPLEURIDAE Angelin, 1854 \\ Genus HYSTRICURUS Raymond, 1913}

Hystricurus Raymond, 1913, p. 60; Ross, 1951, p. 39; Hintze, 1953, p. 164; Sando, 1957. p. 136.

Type species.-Bathyurus conicus Billings, 1859, by original designation.

Discussion.-The generic concept of Hystricurus given by Ross (1951) is followed here.

\section{Hystricurus millardensis Hintze \\ Plate 3, figures 10-16}

Hystricurus millardensis Hintze, 1953, p. 168, pl. 6, figs. 1721; Winston and Nicholls, 1967, p. 76, pl. 12, figs. 14, 18; Stitt, 1971, p. 46, pl. 8, figs. 17, 18.

Material available.-Fourteen cranidia, two incomplete librigena, and one pygidium from locality $\mathrm{H}-2$.

Description of Whitehall material.-Cranidium subrectangular in outline, strongly convex. Glabella conical, tapered forward, anterior end bluntly rounded, length 0.6 cranidial length, length 0.9 basal glabellar width. Axial glabellar furrows deeply impressed laterally, less deeply impressed anteriorly, fossulae present at anterolateral corners of glabella.
Lateral glabellar furrows expressed as oval-shaped regions without prosopon in position of S1 and S2. Occipital ring simple, straight, well defined by deep occipital furrow. Medial region of occipital ring lacking node or spine. Frontal area length 0.2 cranidial length (sag.). Preglabellar field sagittally convex, downsloping. Anterior border convex, evenly rounded in lateral profile, length (sag.) about $\mathbf{0 . 5}$ preglabellar field length (sag.). Anterior margin evenly rounded in dorsal view. Anterior fixigena strongly downsloping anterolaterally. Interocular fixigena convex, below level of glabellar surface at midline, width 0.45 adjacent glabellar width. Posterior fixigena subtriangular, width (tr.) 0.75 width (tr.) occipital ring. Eye ridge weakly developed. Palpebral lobe lunate, subhorizontal, raised above level of interocular librigena, length (exsag.) 0.45 glabellar length, centered opposite L2. Facial sutures opisthoparian. Preocular sutures divergent, straight, directed downward anterolaterally. Postocular suture strongly divergent, nearly straight.

Librigena known from fragments, ellipsoidal in outline, strongly convex. Genal field evenly convex, strongly downsloping. Eye socle raised above level of genal field. Lateral border strongly convex, strongly differentiated by deep lateral furrow. Genal spine not observed.

Thorax unknown.

Pygidium subelliptical in outline, strongly convex, length (sag.) 0.5 width. Axis convex, strongly tapering posteriorly to border. Four axial rings and terminal piece, fourth ring weakly differentiated. Pleural regions strongly downsloping, three pairs moderately deep interpleural furrows, two pairs moderately shallow pleural furrows. Border defined by change in slope from pleural regions, not crossed by pleural furrows.

Cranidial prosopon consists of large closely spaced perforate granules, except in furrows and on the border. Fine closely spaced granules are interspersed between large granules and occupy furrows. The anterior border has well-developed terrace lines on the distal side and a few scattered granules on the proximal side.

The single librigena has large closely spaced perforate granules on the genal field and fine closely spaced granules in the border furrow. The border possesses a few granules on the proximal side and terrace lines on the distal side. Genal caeca are faintly visible radiating from the base of the eye socle into the border furrow. Caeca are under, rather than between, large perforate granules. 
The pygidium has large perforate granules more widely spaced than on the cranidia and librigena. Interspaces contain fine closely spaced granules. Axial rings possess an additional pair of relatively large granules symmetrical about the sagittal plane. Terrace lines are present on the border.

Internal molds of cranidia have scattered fine pits.

Discussion.-Hystricurus millardensis was originally described from the lower part of Symphysurina $B$ Zone in the House Limestone of the Southern House Range, west-central Utah (Hintze, 1952). The Whitehall specimens differ from the House material in possessing granular prosopon on librigenae.

Winston and Nicholls (1967) attributed material to $H$. millardensis from the Symphysurina Zone of the Wilberns Formation, central Texas. The only observed difference between Whitehall and Wilberns specimens is the apparent absence of granule-free glabellar furrow areas in the Texas material.

Stitt (1971) attributed specimens from the Symphysurina Zone at the base of the McKenzie Hill Limestone of south-central Oklahoma to $H$. millardensis. The Oklahoma material differs from Whitehall specimens in lacking granule-free glabellar furrow areas and in possessing granules rather than pits on surfaces of internal molds (Stitt, 1971, p. 46). These differences are not considered taxonomically significant.

Flower (1969, p. 33, pl. 7, fig. 4) described and illustrated a cranidium from the Fort Ann Limestone, east of Smith Basin, N. Y., which he assigned to Hystricurus cf. conicus (Billings). The cranidium differs from material known from the Whitehall Formation in having a less tapered glabella, less deeply impressed fossulae, and coarse-textured granular prosopon.

Occurrence.-Missisquoia Zone, locality H-2, upper Whitehall Formation, Washington County, N.Y.

\section{DESCRIPTION OF FOSSIL LOCALITIES}

All fossil localities studied are described below with reference to the southwest quarter of the Whitehall 71/2-minute quadrangle, New York-Vermont, 1950 edition, Washington County, N.Y. Coordinates are given following a system often used by Franco Rasetti, where the abscissa $(x)$ and ordinate $(y)$ are given in millimeters from the origin at the lower left, southwest corner of the map. Color designations are based on the "Rock-Color Chart" of the National Research Council (Goddard, 1948).
H-1.-Lower Whitehall Formation. Sample composed of light- to medium-gray ( $N$ 5-7) ooidskeletal grainstone collected at the east end of Crossman quarry (inactive), near the road entrance to the quarry, in place 11 feet above quarry floor. Crossman quarry is on the north side of Washington County Route 10 (Sciota Road) and the south side of a low hill immediately south of Finch Marsh. Map coordinates, $x=396, y=323$. Collected by R. B. Halley, July 7, 1970. Filed in the U.S. Geological Survey collections in Washington, D.C., under number 7602-CO.

H-2. Upper Whitehall Formation. Sample composed of medium-gray ( $N 5$ ) lime mudstone collected in place from the southwest corner of Warner Hill, at about 400 feet elevation, north of Finch Marsh. Map coordinates, $x=398, y=378$. Collected by $\mathrm{R}$. B. Halley, June 16, 1970. Filed in the U.S. Geological Survey collections in Washington, D.C., under number 7603-CO.

H-3.-Lower Whitehall Formation. Sample composed of light- to medium-gray ( $N$ 5-7) ooidskeletal grainstone collected in place from the northwest side of Warner Hill, about 800 feet southeast from cluster of buildings immediately east of School House Marsh, between 200 and 300 feet elevation. Map coordinates, $x=404$, $y=413$. Collected by R. B. Halley, June 16, 1970 . Filed in the U.S. Geological Survey collections in Washington, D.C., under number 7604-CO.

$418 \mathrm{e}$ (old series).-Sample composed of light- to medium-gray skeletal packstone collected "two miles north-northeast of Whitehall, New York," by C. D. Walcott, date unknown. Locality data are insufficient for determining the precise collecting locality. The sample may have come from either the Crossman quarry area along Washington County Route 10, or Warner Hill. (See fig. 1 for general location.)

U.S. Geological Survey files contain a copy of the Whitehall, New York-Vermont, 15-minute quadrangle, 1902 edition, used by Josiah Bridge to record the location of fossil collections $470 \mathrm{~b}$, $470 \mathrm{~b}_{1}$ and $473 \mathrm{f}$. These localities were replotted on the southwest quarter of the Whitehall $71 / 2$ minute quadrangle, 1950 edition, and coordinates were determined which are given below.

$470 \mathrm{~b}$ (old series).-Dample composed of mediumgray ( $N$ 5-6) ooid-skeletal grainstone and packstone. "Hall farm, one mile northeast of Whitehall, N.Y. All material except 'crytozoans' from 
one boulder." Replotted map coordinates, $x=381$, $y=295$. Collected by E. O. Ulrich, Rudolph Ruedemann, and Josiah Bridge, July 8, 1931.

$470 \mathrm{~b}_{1}$ (old series).- Sample composed of mediumgray ( $N$ 5-6) ooid-skeletal grainstone. Location same as 470b except: "100 feet above 470 b." Replotted map coordinates, $x=386, y=292$.

$473 \mathrm{f}$ (old series).-Sample composed of medium gray (N 4-6) ooid grainstone and boundstone from Finch farm, at bend in road one-eighth of a mile east of E. A. Martin house. One loose block. Replotted map coordinates, $x=389, y=321$. Apparently collected a few feet west of the entrance to Crossman quarry. Collected by E. O. Ulrich, Rudolph Ruedemann, and Josiah Bridge, July 8, 1931.

7098-CO.-Upper Whitehall Formation. Sample composed of light- to medium-gray $\left(N_{6-7}\right)$ ooidlithoclast grainstone collected near top of Skene Mountain at junction of foot trail and a line bearing $\mathrm{S} .10^{\circ} \mathrm{E}$. for about 100 yards from a red communications tower located at the high point on the mountain. Collected in place from limestone beds forming blocky outcrops on dip slope overlying sandy and cherty dolomite beds. Map coordinates, $x=348, y=260$. Collected by M. E. Taylor and J. E. Taylor, September 23, 1971.

7099-CO._Same locality and rock type as 7098-CO except different bed, one foot lower in section.

\section{REFERENCES CITED}

Ahr, W. M., 1971, Paleoenvironment, algal structures, and fossil algae in the Upper Cambrian of central Texas: Jour. Sed. Petrology, v. 41, p. 205-216.

Aitken, J. D., 1967, Classification and environmental significance of cryptalgal limestones and dolomites, with illustrations from the Cambrian and Ordovician of southwestern Alberta: Jour. Sed. Petrology, v. 37, no. 4, p. 1163-1178.

Aitken, J. D., and Norford, B. S., 1967, Lower Ordovician Survey Peak and Outram Formations, southern Rocky Mountains of Alberta: Bull. Canadian Petroleum Geology, v. 15, no. 2, p. 150-207.

Angelin, N. P., 1854, Palaeontologica Scandinavica. Pt. II : Academiae Regiae Scientarium Suecanae (Holmiae), p. 21-92.

Bell, W. C., Berg, R. R., and Nelson, C. A., 1956, Croixan type area-Upper Mississippi Valley, in Rodgers, John ed., El Sistema Cámbrico, su paleogeografía y el problema de su base-symposium, pt. 2: Internat. Geol. Cong., 20th, Mexico City, 1956, p. 415-446.

Bell, W. C., and Ellinwood, H. L., 1962, Upper Franconian and lower Trempealeauan Cambrian trilobites and brachiopods, Wilberns Formation, central Texas: Jour. Paleontology, v. 36 , no. 3, p. 385-423.
Billings, Elkanah, 1860, On some new species of fossils from the limestone near Point Lévis opposite Quebec: Canadian Naturalist and Geologist, v. 5, p. 301-324. 1865, Palaeozoic fossils, volume 1; Containing descriptions and figures of new or little known species of organic remains from the Silurian rocks: Canada Geol. Survey, $426 \mathrm{p}$.

Bird, J. M., and Dewey, J. F., 1970, Lithosphere plate-continental margin tectonics and the evolution of the Appalachian orogen: Geol. Soc. America Bull., v. 81, no. 4, p. 1031-1060.

Bird, J. M., and Rasetti, Franco, 1968, Lower, Middle, and Upper Cambrian faunas in the Taconic sequence of eastern New York-Stratigraphic and biostratigraphic significance: Geol. Soc. America Spec. Paper 113, 66 p.

Bridge, Josiah, and Cloud, P. E., Jr., 1947, New gastropods and trilobites critical in the correlation of Lower Ordovician rocks: Am. Jour. Sci., v. 245, no. 9, p. 545-559.

Cheetham, A. H., and Hazel, J. E., 1969, Binary (presenceabsence) similarity coefficients: Jour. Paleontology, v. 43 , no. 5 , p. $1130-1136$.

Clark, M. G., and Shaw, A. B., 1968, Paleontology of northwestern Vermont. XVI, Trilobites of the Upper Cambrian Gorge Formation (upper Bed 3): Jour. Paleontology, v. 42, no. 4, p. 1014-1026.

Cleland, H. F., 1900, The Calciferous of the Mohawk Valley: Bulls. Am. Paleontology no. 13, 26 p.

Dake, C. L., and Bridge, Josiah, 1932, Faunal correlation of the Ellenburger Limestone of Texas: Geol. Soc. America Bull., v. 43, no. 3, p. 725-741.

Davies, G. R., 1970, Algal-laminated sediments, Gladstone embayment, Shark Bay, Western Australia: Am. Assoc. Petroleum Geologists Mem. 13 p. 169-205.

Derby, J. R., Lane, H. R., and Norford, B. S., 1972, Uppermost Cambrian-basal Ordovician faunal succession in Alberta and correlation with similar sequences in the western United States: Internat. Geol. Cong., 24th, Montreal, 1972, Proc., v. 7, p. 503-512.

Dunham, R. J., 1962, Classification of carbonate rocks according to depositional texture, in Ham, W. E., ed., Classification of carbonate rocks-A symposium: Am. Assoc. Petroleum Geologists Mem. 1, p. 108-121.

Dwight, W. B., 1886a, Primordial rocks of the Wappinger Valley Limestones: Vassar Brothers Inst. Trans., v. 4, p. 130-141.

1886b, Recent explorations in the Wappinger Valley Limestone of Dutchess County, New York; No. 5, Discovery of fossiliferous Potsdam strata at Poughkeepsie, New York: Am. Jour. Sci., 3d ser., v. 31, p. 125-133.

- 1887, Primordial rocks of the Wappinger Valley Limestones and associated strata: Vassar Brothers Inst. Trans., v. 4, p. 206-214.

Endo, Riuji, and Resser, C. E., 1937, The Sinian and Cambrian formations and fossils of southern Manchoukuo: Manchurian Sci. Mus. Bull. 1, 474 p.

Field, R. M., 1915, On the validity of the genus Plethopeltis (Raymond): Ottawa Naturalist, v. 29 , p. 37-43.

Fisher, D. W., 1956, The Cambrian System of New York State, in Rodgers, John, ed., El Sistema Cámbrico, su paleogeografía y el problema de su base-symposium, pt. 2: Mexico, D. F., Internat. Geol. Cong., 20th, Mexico City, 1956, p. 321-351. 
1962, Correlation of the Cambrian rocks in New York State: New York State Mus. and Sci. Service, Geol. Survey, Map and Chart Ser. 2.

1968, Geology of the Plattsburgh and Rouses Point, New York-Vermont, quadrangles: New York State Mus. and Sci. Service, Geol. Survey, Map and Chart Ser. $10,51 \mathrm{p}$.

1969, Paleozoic geology of the Lake George-Glens Falls-Fort Ann, New York, region [abs.]: Geol. Soc. America Abs. with Programs, [v. 1], pt. 1, p. 19.

Fisher, D. W., and Hanson, G. F., 1951, Revisions in the geology of Saratoga Springs, New York, and vicinity: Am. Jour. Sci., v. 249 , no. 11, p. 795-814.

Flower, R. H., 1964, The nautiloid order Ellesmeroceratida (Cephalopoda): New Mexico Bur. Mines and Mineral Resources Mem. 12, 234 p.

1969, Fossils from the Fort Ann Formation: New Mexico Bur. Mines and Mineral Resources Mem. 22, p. 29-34, 58-59.

Folk, R. L., and Pittman, J. S., 1971, Length-slow chalcedony; a new testament for vanished evaporites: Jour. Sed. Petrology, v. 41 no. 4, p. 1045-1058.

Gebelein, C .D., and Hoffman, Paul, 1969, Intertidal stromatolites from Cape Sable, Florida [abs.]: Geol. Soc. America Spec. Paper 121, p. 109.

Gill, E. D., 1949, Prosopon, a term proposed to replace the biologically erroneous term ornament: Jour. Paleontology, v. 23 , no. 5 , p. $572-573$.

- 1951, Concerning the substitution of the term prosopon for ornament: Jour. Paleontology, v. 25, no. 3, p. 408-409.

Ginsburg, R. N., 1956, Environmental relationships of grain size and constituent particles in some south Florida carbonate sediments: Am. Assoc. Petroleum Geologists Bull., v. 40 , no. 10, p. 2384-2427.

Ginsburg, R. N., Ishum, L. B., Bein, S. J., and Kuperberg, J., 1954, Laminated algal sediments of south Florida and their recognition in the fossil record: Miami Univ. Inst. Marine Sci. Marine Lab. [unpub. rept.] 54-20, 33 p.

Goddard, E. N., chm., and others, 1948, Rock-color chart: Washington, Natl. Research Council (repub. by Geol. Soc. America, 1951, reprinted 1963), 6 p.

Grant, R. E., 1965, Faunas and stratigraphy of the Snowy Range Formation (Upper Cambrian) in southwestern Montana and northwestern Wyoming: Geol. Soc. America Mem. 96, 171 p.

Hall, James 1863, Preliminary notice of the fauna of the Potsdam Sandstone***: New York State Cabinet, Ann. Rept. 16, p. 119-222.

Halley, R. B., 1971a, Paleoenvirnmental interpretatins of the Upper Cambrian Cryptalgal limestones of New York State: Providence, R.I., Brown Univ., unpub. M.S. thesis, $93 \mathrm{p}$.

1971b, Crytalgal limestones of the Hoyt (U. Cambrian) and Whitehall (U. Cambrian to L. Ordovician) formations of New York State [abs.]: Geol. Soc. America Abs. with Programs, v. 3, no. 1, p. 35.

Harrington, H. J., and others, 1959, Arthropoda 1*** Part O of Moore, R. C., ed., Treatise on invertebrate paleontology: New York and Lawrence, Kans., Geol. Soc. America and Univ. Kansas Press, 560 p.

Henningsmoen, Gunnar, 1957, The trilobite family Olenidae: Norske Vidensk.-Abad., Oslo Mat.-Naturv. Kl., Skr., no. $1,303 \mathrm{p}$.
Hintze, L. F., 1952, Lower Ordovician trilobites from western Utah and eastern Nevada: Utah Geol. and Mineralog. Survey Bull. 48, 249 p. [1953].

Hoffman, P. L., Logan, B. W., and Gebelein, C. D., 1969, Biological versus environmental factors governing the morphology and internal structure of Recent stromatolites in Shark Bay, Western Australia [abs.]: Geol. Soc. America Abs. with Programs, [v. 1], pt. 1, p. 28-29.

Howell, B. F., 1945, Revision of the Upper Cambrian faunas of New Jersey: Geol. Soc. America Mem. 12, 46 p.

Howell, B. F., and others, 1944, Correlation of the Cambrian formations of North America: Geol. Soc. America Bull., v. 55, no. 8, p. 993-1003.

Hupé, Pierre, 1953, Classification des trilobites: Annales paléontologie, v. 39 , p. 59-168.

Imbrie, John, and Buchanan, Hugh, 1965, Sedimentary structures in modern carbonate sands of the Bahamas: Soc. Econ. Paleontologists and Mineralogists Spec. Pub. 12, p. 149-172.

International Committee on Zoological Nomenclature, 1964, International code of zoological nomenclature: London, $176 \mathrm{p}$.

Isachsen, Y. W., and Fisher, D. W., comps. and eds., 1971, Geologic map of New York, 1970. Adirondack Sheet: New York Mus. and Sci. Service Map and Chart Ser. 15.

Kendall, C. G. St. C., and Skipwith, P. A. 1968, Recent algal mats of a Persion Gulf lagoon: Jour. Sed. Petrology, v. 38, p. 1040-1058.

Kindle, C. H., and Whittington, H. B., 1958, Stratigraphy of the Cow Head region, western Newfoundland: Geol. Soc. America Bull., v. 69, no. 3, p. 315-342.

1959, Some stratigraphic problems of the Cow Head area in western Newfoundland: New York Acad Sci. Trans., ser. 2, v. 22, no. 1, p. 7-18.

Klein, G. deV., 1972, Determination of paleotidal range in clastic sedimentary rocks: Internat. Geol. Cong., 24th, Montreal, Proc., v. 6, p. 397-405.

Kobayashi, Teiichi, 1935, The Cambro-Ordovician formations and faunas of south Chosen; Paleontology; Pt. 3. Cambrian faunas of south Chosen with a special study on the Cambrian trilobite genera and families: Tokyo Imp. Univ., Fac. Sci. Jour., sec. 2, v. 4, pt. 2, $344 \mathrm{p}$.

- 1942, On the Dolichometopinae: Tokyo Imp. Univ., Fac. Sci. Jour., sec. 2, v. 6, pts. 4-10, p. 141-206.

1956, On the Kaolishaniinae: Japanese Jour. Geology and Geography, v. 27 , no. 1, p. 9-20.

Laporte, L. F., 1967 Carbonate deposition near mean sea level and resultant facies mosaic-Manlius Formation (Lower Devonian) of New York State: Am. Assoc. Petroleum Geologists Bull., v. 51, no. 1, p. 73-101.

1971, Paleozoic carbonate facies of the central Appalachian shelf: Jour. Sed. Petrology, v. 41, no. 3, p. 724-740.

Lochman, Christina, 1946, Two Upper Cambrian (Trempealeau) trilobites from Dutchess County, New York: Am. Jour. Sci., v. 244, no. 8, p. 547-553.

1964a, Upper Cambrian faunas from the subsurface Deadwood Formation, Williston Basin, Montana: Jour. Paleontology, v. 38, no. 1. p. 33-60.

$1964 \mathrm{~b}$, Basal Ordovician faunas from the Williston Basin, Montana: Jour. Paleontology, v. 38, no. 3, p. 453-476. 
1970, Upper Cambrian faunal patterns on the craton: Geol. Soc. America Bull., v. 81, no. 11, p. 3197-3224.

- 1971, The Cambrian of the craton of the United States, in Holland, C. H., ed., Cambrian of the New World: New York, Interscience Publishers, p. 79-167.

Lochman, Christina, and Wilson, J. L., 1958, Cambrian biostratigraphy in North America: Jour. Paleontology, v. 32 , no. 2 , p. $312-350$.

1967 Stratigraphy of Upper Cambrian-Lower Ordovician subsurface sequence in Williston Basin: Am. Assoc. Petroleum Geologists Bull., v. 51, no. 6, pt. 1, p. 883-917.

Logan, B. W., 1961, Cryptozoon and associate stromatolites from the Recent, Shark Bay, Western Australia: Jour. Geology, 69, no. 5, p. 517-533.

Logan, B. W., and Cebulski, D. E., 1970, Sedimentary environments of Shark Bay, Western Australia: Am. Assoc. Petroleum Geologists Mem. 13, p. 1-37.

Logan, B. W., Read, J. F., and Davies, G. R., 1970, History of carbonate sedimentation, Quaternary Epoch, Shark Bay, Western Australia: Am. Assoc. Petroleum Geologists Mem. 13, p. 38-84.

Logan, B. W., Rezak, R., and Ginsburg R. N., 1964, Classification and environmental significance of algal stromatolites: Jour. Geology, v. 72 , no. 1, p. 68-83.

Longacre, S. A., 1970, Trilobites of the Upper Cambrian ptychaspid biomere, Wilberns Formation, central Texas: Paleont. Soc. Mem. 4 (Jour. Paleontology, v. 44, no. 1, supp.), $61 \mathrm{p}$.

Mansuy, H., 1915, Faunes cambriennes du Haut-Tonkin: Indochina Service Géol. Mém., v. 4, no. 2, p. 1-35.

Margolis, S. V., 1968, Electron microscopy of chemical solution and mechanical abrasion features on quartz sand grains: Sed. Geology, v. 2, no. 4, p. 243-256.

Mello, J. F., and Buzas, M. A. 1968, An application of cluster analysis as a method of determining biofacies: Jour. Paleontology, v. 42, no. 3, p. 747-758.

Mudge, M. R., and Yochelson, E. L., 1962, Stratigraphy and paleontology of the uppermost Pennsylvanian and lowermost Permian rocks in Kansas: U.S. Geol. Survey Prof. Paper 323, $213 \mathrm{p}$.

Nelson, C. A., 1951, Cambrian trilobites from the St. Croix Valley: Jour. Paleontology, v. 25, no. 6, p. 765-784.

1953, Revision of Croixan dikelocephalids-A comment: Jour. Paleontology, v. 27, no. 5, p. 734-736. - 1956, Upper Croixan stratigraphy, Upper Mississippi Valley: Geol. Soc. America Bull., v. 67, no. 2, p. 165184.

Norford, B. S., 1969, The Early Canadian (Tremadocian) trilobites Clelandia and Jujuyaspis from the southern Rocky Mountains of Canada: Canada Geol. Survey Bull. 182 , p. $1-15$.

Palmer, A. R., 1960, Some aspects of the early Upper Cambrian stratigraphy of White Pine County, Nevada, and vicinity: Intermountain Assoc. Petroleum Geologists, 11th Ann. Field Conf., 1960, Guidebook, p. 53-58.

- 1965, Trilobites of the Late Cambrian pterocephaliid biomere in the Great Basin, United States: U.S. Geol. Survey Prof. Paper 493, 105 p.

1968, Cambrian trilobites of east-central Alaska: U.S. Geol. Survey Prof. Paper 559-B, 115 p.

1969, Cambrian trilobite distributions in North America and their bearing on Cambrian paleogeography of Newfoundland: Am. Assoc. Petroleum Geologists Mem. 12, p. 139-144.

1971a, The Cambrian of the Great Basin and adjacent areas, western United States, in Holland, C. H., ed., Cambrian of the New World, New York, Interscience Publishers, p. 1-78.

1971b, The Cambrian of the Appalachian and eastern New England regions, eastern United States, in Holland, C. H., ed., Cambrian of the New World. New York, Interscience Publishers, p. 169-217.

- 1972, Problems of Cambrian biogeography: Internat. Geol. Cong., 24th, Montreal, 1972, Proc. v. 7, p. 310315.

1973, Cambrian trilobites, in Hallam, Anthony, ed., Atlas of palaeobiogeography: Amsterdam, Elsevier Sci. Pub. Co., p. 3-11.

Raasch, G. O., 1951, Revision of Croixan dikelocephalids: Illinois State Acad. Sci. Trans. v. 44, p. 137-151; reprinted as: Illinois State Geol. Survey Circ. 179, 1952.

Rasetti, F. R. D., 1944, Upper Cambrian trilobites from the Lévis Conglomerate: Jour. Paleontology, v. 18, no. 3, p. 229-258.

1945, New Upper Cambrian trilobites from the Lévis Conglomerate: Jour. Paleontology, v. 19, no. 5, p. $462-478$.

- 1946, Revision of some late Upper Cambrian trilobites from New York, Vermont and Quebec: Am. Jour. Sci.. v. 244 , no. 8 , p. 537-546.

- 1954, Phylogeny of the Cambrian trilobite family Catillicephalidae and the ontogeny of Welleraspis: Jour. Paleontology, v. 28, no. 5, p. 599-612.

1959, Trempealeauian trilobites from the Conococheague, Frederick, and Grove Limestones of the central Appalachians: Jour. Paleontology, v. 33, no. 3, p. 375-398.

- 1963, Additions to the Upper Cambrian fauna from the conglomerate boulders at Lévis, Quebec: Jour. Paleontology, v. 37, no. 5, p. 1009-1017.

Raymond, P. E., 1913, a revision of the species which have been referred to the genus Bathyurus: Canada Geol. Survey, Victoria Memorial Mus. Bull. 1, p. 51-69.

— 1924, New Upper Cambrian and Lower Ordovician trilobites from Vermont: Boston Soc. Nat. History Proc., v. 37 , no. 4, p. 389-466; also pub. as: Vermont State Geologist 14th Bienn. Rept. p. 137-203 (reprint with changes by Raymond).

1937, Upper Cambrian and Lower Ordovician Trilobita and Ostracoda from Vermont: Geol. Soc. America Bull., v. 48 , no. 8, p. 1079-1146.

1938, Corrections and emendations: Geol. Soc. America Bull., v. 48 (supp.), p. xv.

Resser, C. E., 1942, New Upper Cambrian trilobites: Smithsonian Misc. Colln., v. 103, no. 5, Pub. 3693, 136 p.

Robison, R. A., and Pantoja-Alor, Jerjes, 1968, Tremadocian trilobites from the Nochixtlán region, Oaxaca, Mexico: Jour. Paleontology, v. 42, no. 3, p. 767-800.

Rodgers, John, 1937, Stratigraphy and structure in the upper Champlain Valley: Geol. Soc. America Bull., v. 48 , no. 11 , p. $1573-1588$.

1968, The eastern edge of the North American Continent during the Cambrian and Early Ordovician, in Zen, E-an, and others, eds., Studies of Appalachian geology-northern and maritime: New York, Interscience Publishers, p. 141-149. 
1970, The tectonies of the Appalachians: New York, Interscience Publishers, 271 p.

Roehl, P. O., 1967, Stony Mountain (Ordovician) and Interlake (Silurian) facies analogs of Recent low-energy marine and subaerial carbonates, Bahamas: Am. Assoc. Petroleum Geologists Bull., v. 51, no. 10, p. 1979-2032.

Ross, R. J., Jr., 1951, Stratigraphy of the Garden City Formation in northeastern Utah, and its trilobite faunas: Yale Univ., Peabody Mus. Nat. History Bull. 6, 161 p.

Rowell, A. J., and McBride, D. J., 1972a, A quantitative study of Trempealeauian (latest Cambrian) trilobite faunal provinces in North America [abs.]: Geol. Soc. America, Abs. with Programs, v. 4, no. 4 p. 292-293.

1972b, Faunal variation in the Elvinia zone of the Upper Cambrian of North America-A numerical approach: Internat. Geol. Cong., 24th, Montreal, Proc., v. 7, p. 246-253.

1972c, A quantitative study of Trempealeauian (latest Cambrian) trilobite faunal realms in North America [abs.]: Geol. Soc. America, Abs. with Programs, v. 4, no. 7, p. 645-646.

Rowell, A. J., McBride, D. J., and Palmer, A. R. (1973), A quantitative study of Trempealeauian (latest Cambrian) trilobite faunal distribution in North America: Geol. Soc. America Bull. (In press.)

Sando, W. J., 1957, Beekmantown Group (Lower Ordovician) of Maryland: Geol. Soc. America Mem. 68, 161 p.

Shaw, A. B., 1951, The paleontology of northwestern Vermont. I, New Late Cambrian trilobites: Jour. Paleontology, v. 25 , no. 1 , p. 97-114.

- 1955, The paleontology of northwestern Vermont. IV, A new trilobite genus: Jour. Paleontology, v. 29, no. 1, p. 187.

1958, Stratigraphy and structure of the St. Albans area, northwestern Vermont: Geol. Soc. America Bull., v. 69 , no. 5 , p. 519-568.

Shaw, F. C., and Ormiston, A. R., 1964, The eye socle of the trilobites: Jour. Paleontology, v. 38, no. 5, p. 10011002.

Shinn, E. A., Lloyd, R. M. and Ginsburg, R. N., 1969, Anatomy of a modern carbonate tidal-flat, Andros Island, Bahamas: Jour. Sed. Petrology, v. 39, no. 3, p. 1202-1228.

Simpson, G. G., 1960, Notes on the measurement of faunal resemblance: Am. Jour. Sci., v. 258-A (Bradley Volume) p. 300-311.

Sloss, L. L. 1960, Evolution of concepts on the eastern Great Basin: Intermountain Assoc. Petroleum Geologists, 11th Ann. Field Conf., 1960, Guidebook, p. 1116.

Stitt, J. H., 1971, Late Cambrian and earliest Ordovician trilobites, Timbered Hills and Lower Arbuckle Groups, western Arbuckle Mountains, Murray County, Oklahoma: Oklahoma Geol. Survey Bull. 110, 83 p.

Taylor, M. E., 1969, Biostratigraphy and environments of Upper Cambrian (Upper Franconian-Trempealeauan) strata in the central Great Basin, Utah and Nevada [abs.]: Geol. Soc. America Abs, with Programs, [v. 1], pt. 5 , p. 81 .

- 1971, Biostratigraphy of the Upper Cambrian (Upper Franconian-Trempealeauan Stages) in the central Great Basin, Nevada and Utah: Univ. California, Berkeley, unpub. Ph.D. dissert., $428 \mathrm{p}$.
Theokritoff, George 1964, Taconic stratigraphy in northern Washington County, New York: Geol. Soc. America Bull., v. 75, no. 3, p. 171-190.

Ulrich, E. O., 1930, Systematic paleontology, in Bridge, Josiah, Geology of the Eminence and Cardareva quadrangles: Missouri Bur. Geology and Mines, 2d ser., v. 24 p. 212-222 [1931].

Ulrich, E. O., and Resser, C. E., 1930, The Cambrian of the upper Mississippi Valley; Pt. I, Trilobita; Dikelocephalinae and Osceolinae: Milwaukee Public Mus. Bull., v. 12, no. 1, p. 1-122.

1933, The Cambrian of the Upper Mississippi Valley; Pt. II, Trilobita; Saukiinae: Milwaukee Public Mus. Bull., 12, no. 2, p. 123-306.

Walcott, C. D., 1879, Descriptions of new species of fossils from the Calciferous formation: New York Mus. Ann. Rept. 32, p. 129-131.

1884, Paleontology of the Eureka district [Nevada]: U.S. Geol. Survey Mon. 8, 298 p.

1890, Description of new forms of Upper Cambrian fossils: U.S. Natl. Mus. Proc., v. 13, p. 266-279.

1912a, Cambrian Brachiopoda, Pt. I. Text: U.S. Geol. Survey Mon. 51, 872 p.

1912b, New York Potsdam-Hoyt fauna: Smithsonian Misc. Colln., v. 57, no. 9, p. 251-304.

1914, Dikelocephalus and other genera of the Dikelocephalinae: Smithsonian Misc. Colln., v. 57, no. 13, p. $345-498$.

- 1925, Cambrian geology and paleontology; Part 5, Cambrian and Ozarkian trilobites: Smithsonian Misc. Colln., v. 75, no. 3, p. 59-146.

Wheeler, R. R., 1941, Late Cambrian Saukiinae in the Champlain Valley [abs.]: Geol. Soc. America Bull., 52, no. 12 , pt. 2 , p. 2036-2037.

1942, Cambrian-Ordovician boundary in the Adirondack-border region: Am. Jour. Sci., v. 240, no. 7 , p. 518-524.

Whittington, H. B., 1966, Phylogeny and distribution of Ordovician trilobites: Jour: Paleontology, v. 40, no. 3, p. 696-737.

1968, Zonation and correlation of Canadian and Early Mohawkian Series, in Zen, E-an, and others, eds., Studies of Appalachian geology-northern and maritime: New York, Interscience Publishers, p. 49-60.

Whittington, H. B., and Williams, A. 1964, The Ordovician Period: Geol. Soc. London Quart. Jour., v. 120S, p. 241254.

Wilson, J. L., 1952, Upper Cambrian stratigraphy in the central Applachians: Geol. Soc. America Bull., v. 63, no. 3, p. 275-322.

1954, Late Cambrian and Early Ordovician trilobites from the Marathon uplift, Texas: Jour. Paleontology, v. 28 , no. 3 , p. 249-285.

1956, Revisions in nomenclature and new species of Cambro-Ordovician trilobites from the Marathon uplift, west Texas: Jour. Paleontology, v. 30, no. 6, p. 1341-1349.

Winston, D., and Nicholls, H. 1967, Late Cambrian and Early Ordovician faunas from the Wilberns Formation of central Texas: Jour. Paleontology, v. 41, no. 1, p. $66-96$.

Wright, C. W. 1950, Comment on proposal to substitute Prosopon for ornament: Jour. Paleontology, v. 24, no. 4, p. 497. 


\section{INDEX}

[Italic page numbers indicate major references and descriptions]

A

Page

Acheilops

dilatus

$7,17,19$

masonensis

norwalkensis _..... 19, 20

Acknowledgments

Age and correlations

Agraulos saratogensis

25

Calvinella _...

Analysis methods .............. 15

Apoplanias -..........- 8

apopsis, Corbinia -

arbucklensis, Plethopeltis .............. 25

Arethusina americana ...............- 21

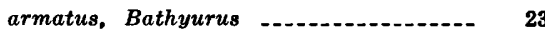

Assemblages dissimilar to Whitehall

fauna --16

Asemblages similar to Whitehall

fauna

$\mathbf{B}$

Bathyurus conicus

Bibliography

Biofacies distribution .................. 12

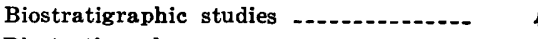

Biostratigraphy
Bowmania

pennsylvanica _..... 4, 5, 7, 16, 21; pl. 2

Briarcliff Dolomite - 6

briarcliffensis, Prosaukia _....... 6, 30

\section{C}

Calvinella

$6,7,17,27,29$

americana -... 30, 31

prethoparia

spiniger -......... 28

walcotti

Cambrian-Ordovician boundary --.--- 8

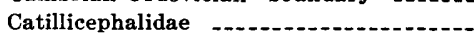

Clelandia

Composition of Whitehall fauna

conicus, Bathyurus

Hystricurus

Conococheague Limestone of Maryland -

convergens, Plethometopus _.......-. 25

Corbinia apopsis _................. 5, 7

Subzone -.......... 7, 8, 9, 20, 24

Correlations and age ..........

Crossman quarry _........... 2, 4, 6, 9, 33

curvicostata, Prosaukia _........ 28

$\mathbf{D}$

delecostata, Prosaukia

depressa, Missisquoia

Dikelocephalidae --

Dikelocephalus misa spiniger

dilatus, Acheilops

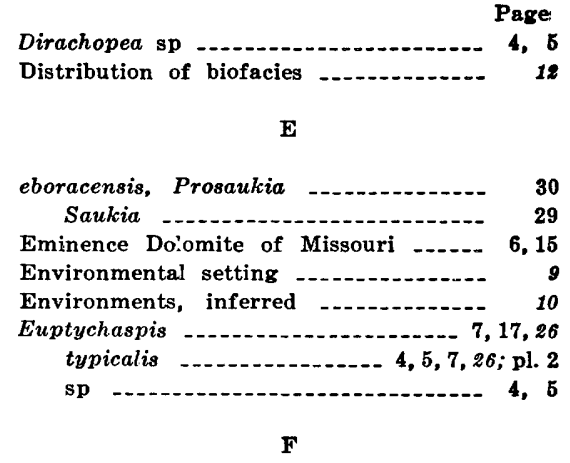

Fort Sill Formation

Fossil collections

Fossil localities, description

Fossils, other, from Whitehall fauna.

G

Garden City Formation Gastropods

Geologic setting granulosa, Plethopeltis

\section{H}

Hedinaspis fauna Heterocaryonidae -................... 21

Highgate Formation ........ 6, 23

Highgatella

Homagnostus _....... 7, 8

House Limestone .

Hoyt Limestone -...... 6, 30

Hoyt Member of Whitehall Formation.- 2

Hungaia magnifica fauna ........ 6,16,18

Hyolithoids _... 4, 5

Hystricurus

conicus --. 32

millardensis _...... 4, 5, 7, 8, s1; pl. 3

sp. D

I

Illaenurus Zone _......... 17

Index of faunal resemblance

$\mathbf{J}$

Jujuyaspis _...... 7

junıa, Saukiella

$\mathbf{K}$

Kittatinny Limestone

knopfi, Plethometopus

15

$\mathbf{L}$

$\mathbf{L}$

Lytospira sp

M

magnifica, Hungaia _.._......... 6, 16, 18

masonensis, Acheilops _-- 4, 5, 7, 16, 19; pl. 1

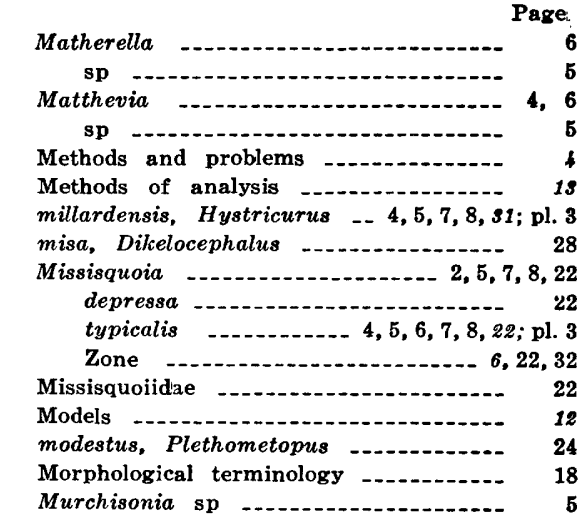

$\mathbf{N}$

norwalkensis, Acheilops _-_._-_._- 19, 20

Saukiella -

Notch Peak Limestone

nuculitiformis, Ribeiria

o

Objectives -

obtusus, Plethometopus ..... 4, 5, 7, 24; pl. 1

Osceolinae _...

Other fossils from Whitehall fauna -.- 4

$\mathbf{P}$

Parabolinella -...

Parakoldinioidia typicalis

Pelagiella -.....-......- 6

pennsylvanica, Bowmania - 4, 5, 7, 16,21; pl. 2

Petrology -....

Plethometopus _............ 7, 16, 17,2s, 25

convergens _-_-_-_._._._.

knopfi

modestus -............. 24

obtusus _.......... 4, 5, 7, 24; pl. 1

sp. A $\ldots \ldots \ldots, 5,7,24 ;$ pl. 1

Plethopeltidae _...

Plethopeltis _............ 4, 7, 8, 16, 17, 25 arbucklensis granulosa _................. 25

sp $\ldots \ldots \ldots \ldots$ 4, 5, 25; pl. 1

Pleurotomariacean gen. indet _..... 5

Potsdam Formation

Potsdam limestone - 6

prethoparia, Calvinella

Previous work -...-..-..- 2

Problems and methods ............ \&

Prosaukia _... 7, 16, 17, 27, 28 briarcliffensis _... 6,30

curvicostata _- 28

delecostata

eboracensis

spinula _............. 4, 5, 7, 29; pl. 2

Ptychaspididae

Ptychaspidinae

pyrene, Saukiella 


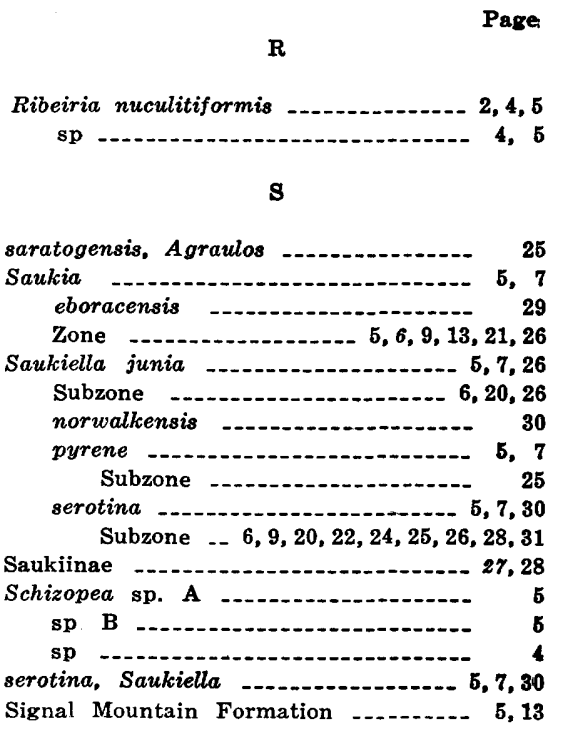

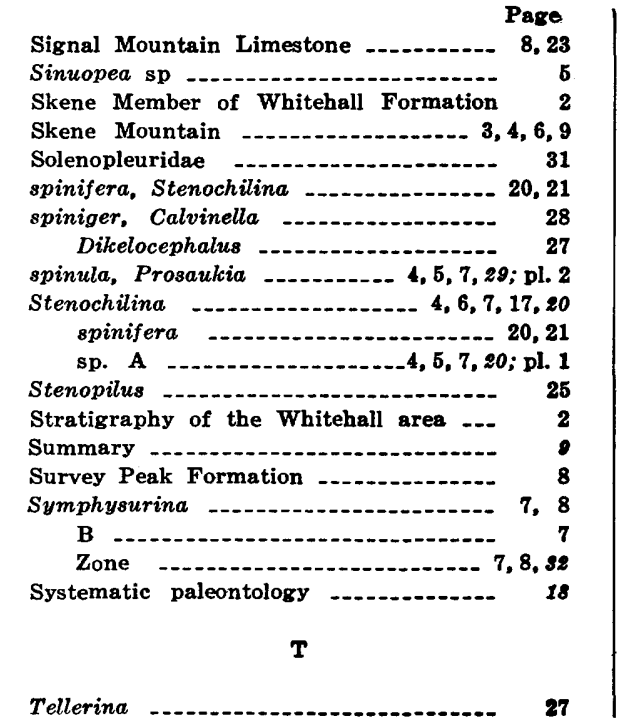

Page

Trona Formation -..............- 2

Trempealeauan fossils _................ 2,16

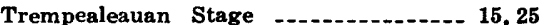

Triarthropsis -...-................ 20

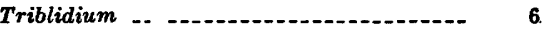

Trilobita

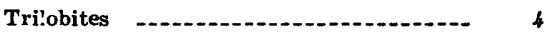

Tub Mountain ................. 9

typicalis, Euptychaspis _...... 4, 5, 7, 26; pl. 2 Missisquoia _........ 4, 5, 6, 7, 8, 22; pl. 3 Parakoldinioidia

\section{W}

Whitehall rauna, assemblages similar to 15 Whitehall fauna, composition -......-. 4 Whitehall Formation ......... 1, 6, 8, 9, 22, 32 Wilberns Formation of Texas -.-. 5, 7, 13, 22 walcotti, Calvinella -................... 30 Warner Hill -........ 2, 6, 8, 9, 32

Whipple Cave Formation -..............- 13

Whitehall fauna, assemblages dissimilar 


\section{PLATES 1-4}

Contact photographs of the plates in this report are available, at cost, from U.S.

Geological Survey Library, Federal Center, Denver, Colorado 80225. 


\section{PLATE 1}

Figures 1-3. Plethopeltis sp. indet. (p. 25).

1. Internal mold of cranidium, USNM 186578, $\times 2.8$, loc. H-3.

2,3. Granidium, USNM 186579, $\times 6.5$, loc. H-3, latex external cast and peripheral part of same cranidium.

4, 5. Acheilops masonensis Winston and Nicholls (p. 19).

4. Librigena, USNM $186580, \times 8.7$, loc. $470 \mathrm{~b}$.

5. Cranidium, USNM $186581, \times 6.2$, loc. $\mathrm{H}-3$.

6-10. Stenochilina sp. A (p. 20).

$6,7,9$. Cranidium, USNM 186582, $\times 6.3$, loc. 418e, lateral, anterior, and dorsal views.

8. Cranidium, USNM $186583, \times 6.7$, loc. $418 \mathrm{e}$.

10. Cranidium, USNM $186584, \times 5.5$, loc. $418 \mathrm{e}$.

11-14. Plethometopus obtusus Rasetti (p. 24).

11-13. Cranidium, USNM 186585, $\times 4.5$, loc. 473f, lateral, anterior, and dorsal views.

14. Cranidium USNM 186586, $\times 5.2$, loc. $473 \mathrm{f}$.

15-17. Plethometopus sp. A (p. 24).

Cranidium, USNM 186587, $\times 6.3$, dorsal, anterior, and lateral views, loc. $473 f$. 
GEOLOGICAL SURVEY
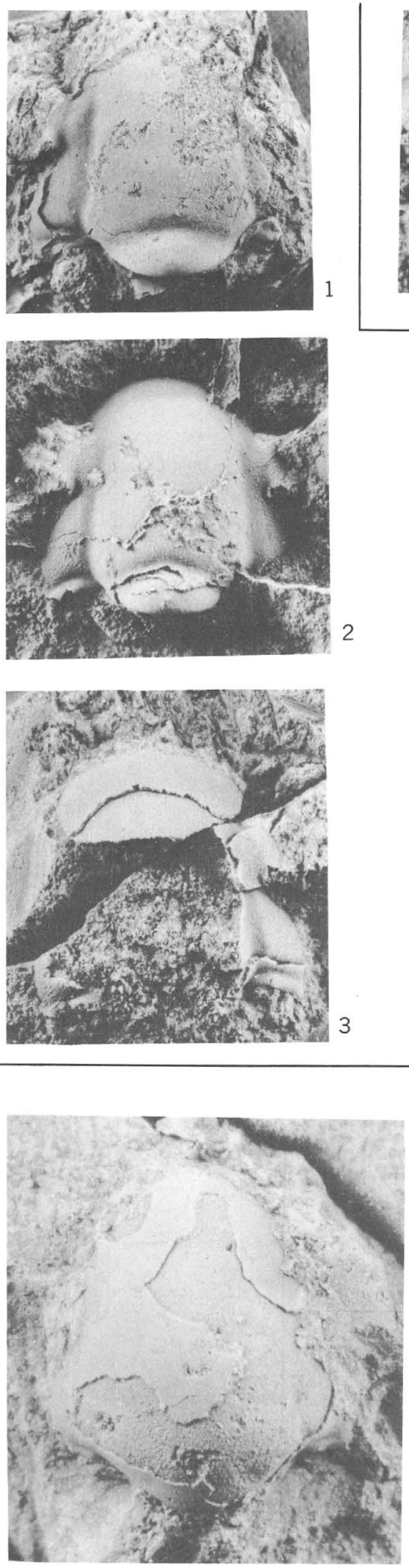

15

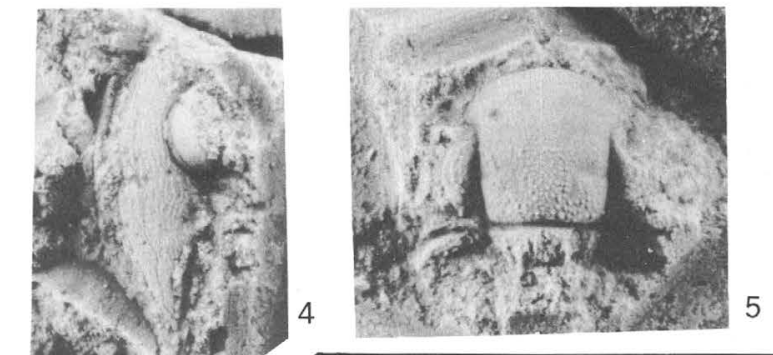

PROFESSIONAL PAPER 834 PLATE 1
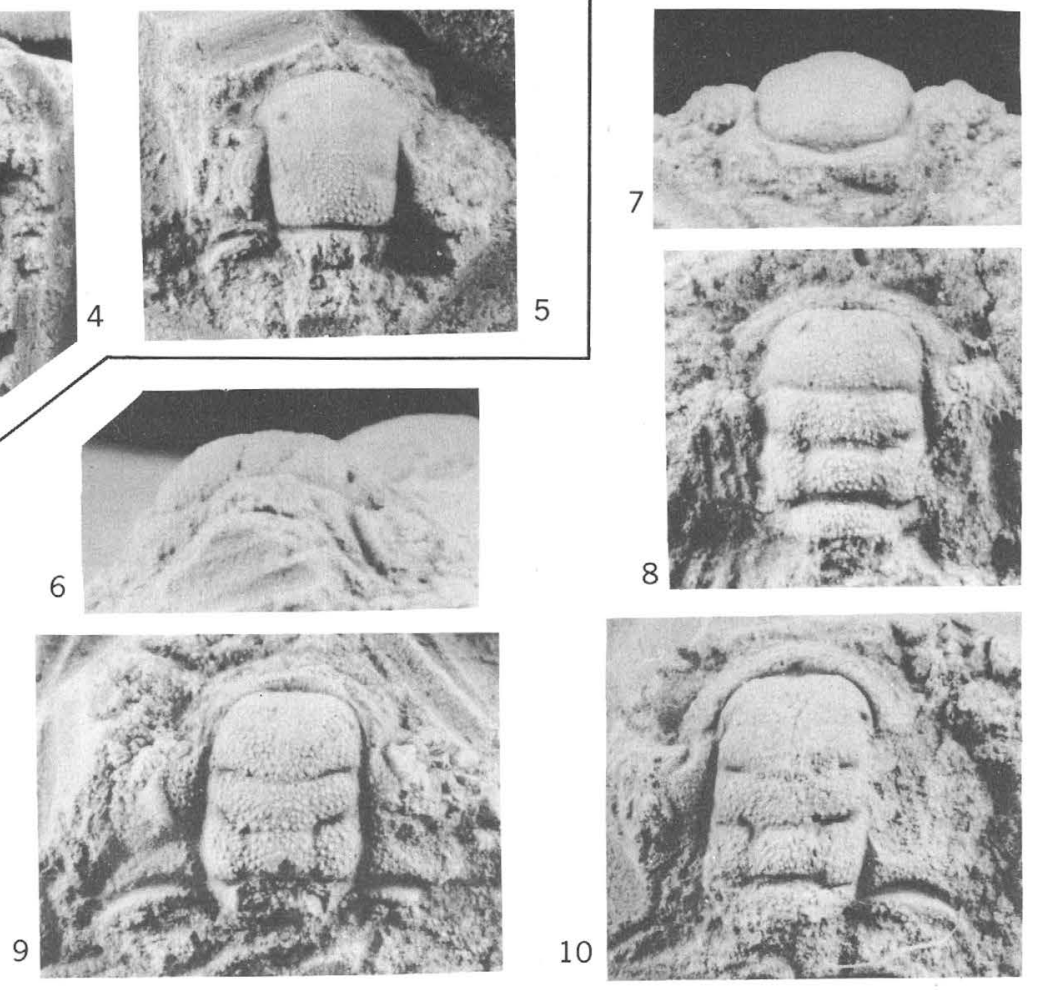

11
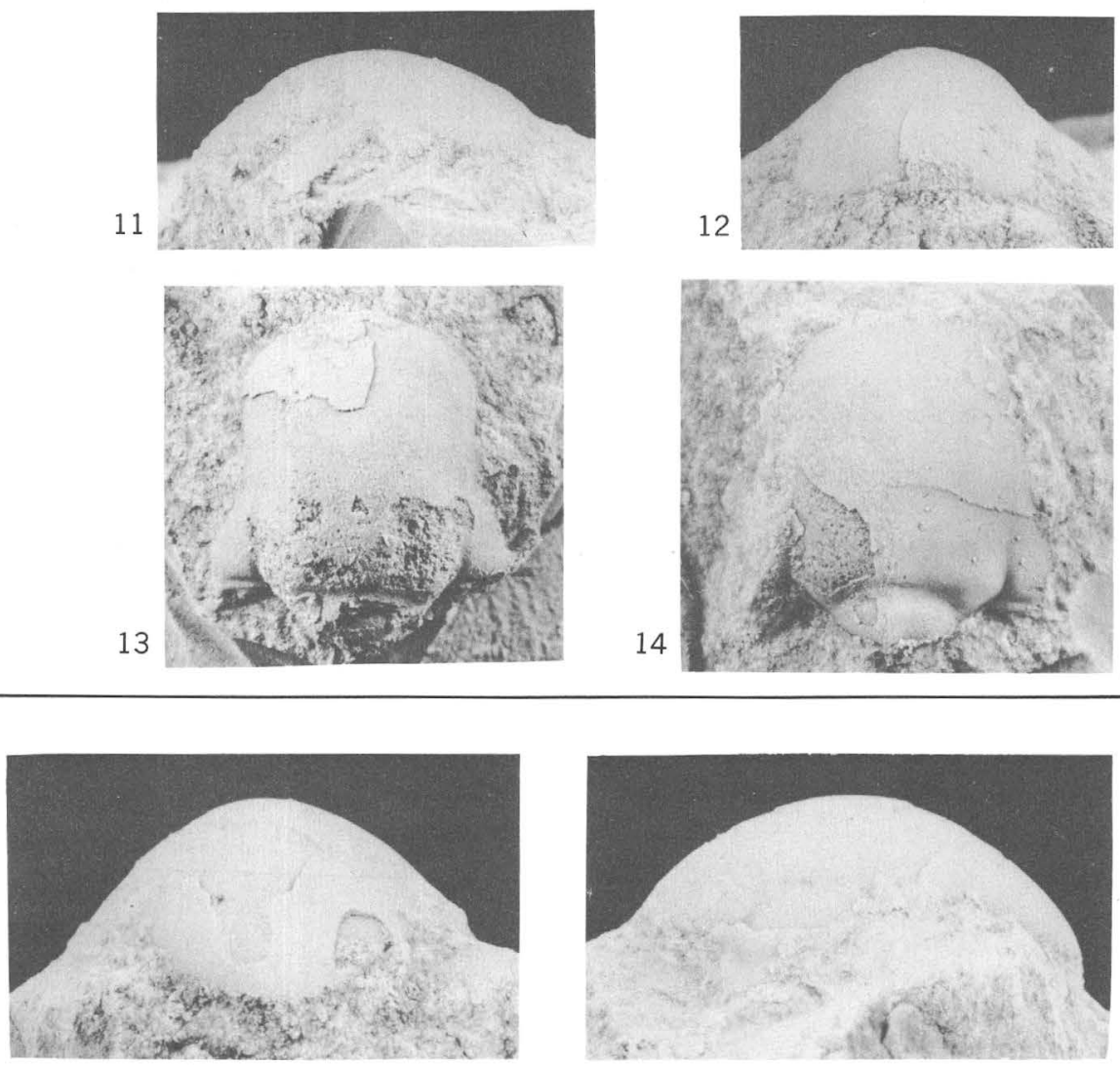

16
17

PLETHOPELTIS, ACHEILOPS, STENOCHILINA, AND PLETHOMETOPUS 


\section{PLATE 2}

Figures 1-3. "Calvinella" prethoparia Longacre (p. 27).

1. Librigena, USNM $186588, \times 6.0$, loc. $\mathrm{H}-1$.

2. Small cranidium, USNM $186589, \times 7.7$, loc. $\mathrm{H}-1$.

3. Large cranidium, USNM $186590, \times 4.3$, loc. H-3, specimen silicified on right side.

4-11. Euptychaspis typicalis Ulrich (p. 26).

Figures 4-7, 10 from loc. $\mathrm{H}-3$; figures 8, 9, 11 from loc. $\mathrm{H}-1$.

4. Cranidium, USNM 186591, $\times 5.8$.

5. Cranidium, USNM $186592, \times 6.9$.

6, 7. Cranidium, USNM $186593, \times 6.9$, dorsal and anterior views.

8, 9. Librigena, USNM $186594, \times 6.1$, lateral and dorsal views.

10. Cranidium, USNM $186595, \times 6.7$.

11. Pygidium, USNM $186596, \times 7.4$.

12-14. Bowmania cf. B. pennsylvanica Rasetti (p. 21).

Cranidium, USNM 186597, $\times 8.2$, dorsal, anterior and lateral views, loc. $\mathrm{H}-1$.

15-20. "Prosaukia" spinula Taylor, n. sp. (p. 29).

Figure 18 from loc. H-3; figures 15-17, 19, 20 from loc. H-1.

15. Holotype cranidium, USNM, 186598, $\times 6.2$.

16. Small paratype cranidium, USNM $186599, \times 6.9$.

17. Paratype cranidium, USNM $186600, \times 9.2$.

18. Latex cast of paratype pygidium, USNM $186601, \times 4.2$.

19. Paratype librigena, USNM $186602, \times 6.3$.

20. Paratype pygidium, USNM $186603, \times 6.5$. 

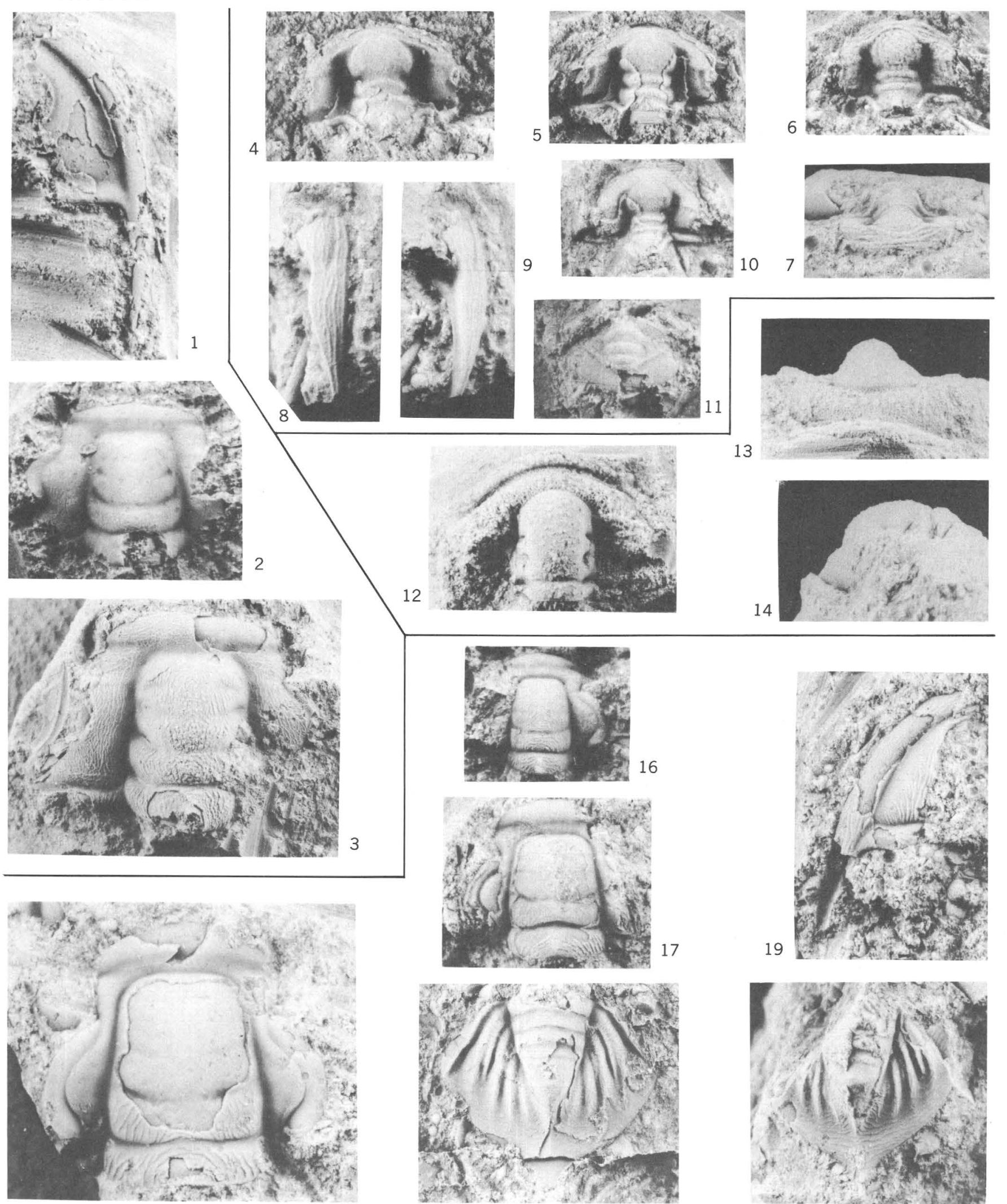

15
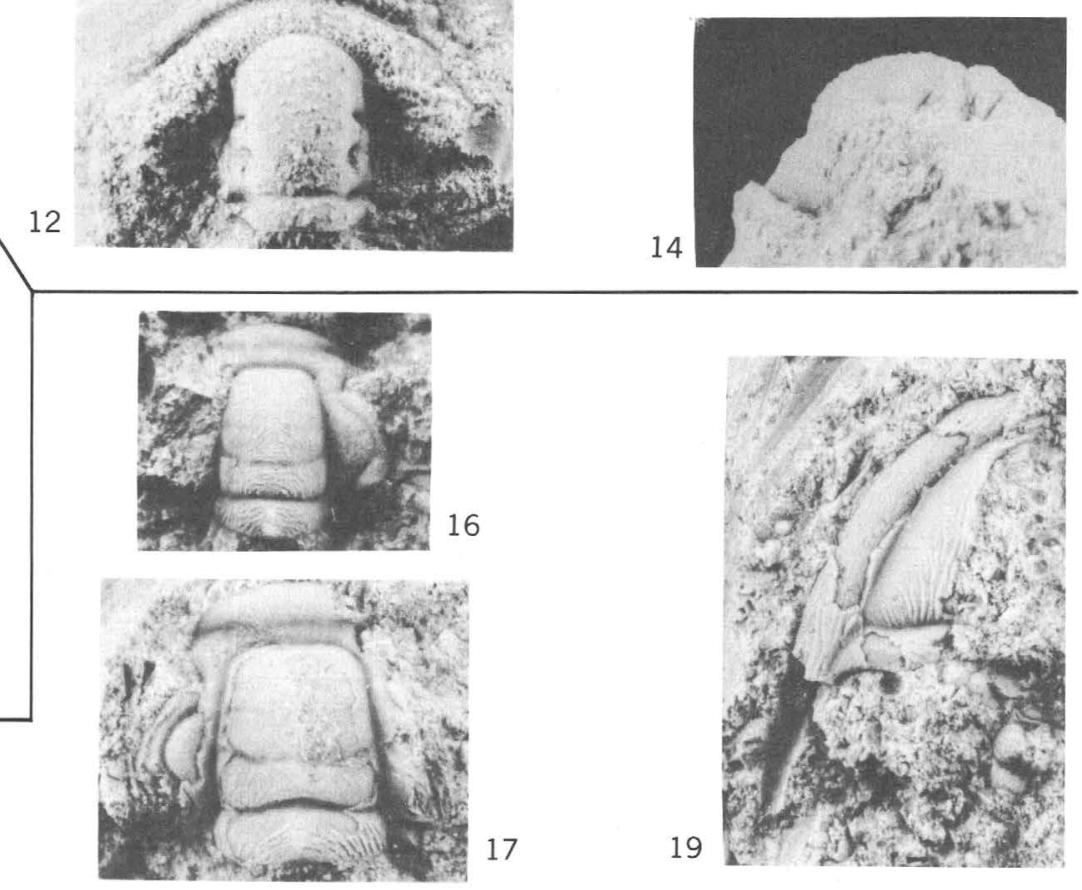

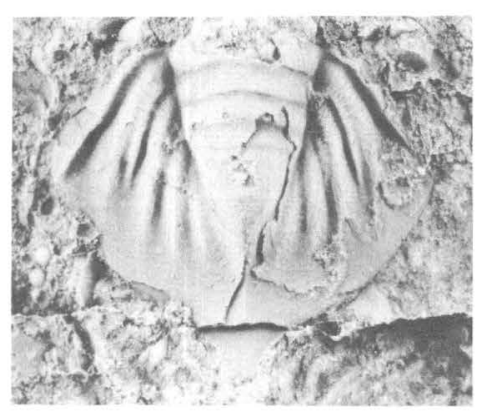

18

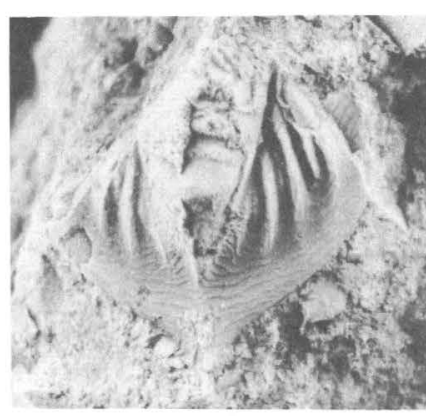

20

"CAL VINELLA," EUPTYCHASPIS, BOWMANIA, AND "PROSAUKIA" 


\section{PLATE 3}

Figures 1-9. Missisquoia typicalis Shaw (p. 22).

Figures 1, 3 from loc. 7098-CO; figures 2, 4, 8 from loc. 7099$\mathrm{CO}$; figures 5-7, 9 from loc. $470 \mathrm{~b}_{1}$.

1. Cranidium, USNM $186604, \times 12.0$.

2. Cranidium, USNM $186605, \times 12.0$.

3. Cranidium, USNM $186606, \times 12.0$.

4. Cranidium, USNM $186607, \times 13.0$.

5. Librigena, USNM $186608, \times 14.0$.

6. Librigena, USNM $186609, \times 9.3$.

7. Cranidium, USNM 186610, $\times 12.5$.

8. Pygidium, USNM 186611, $\times 11.3$.

9. Cranidium, USNM $186612, \times 11.1$.

10-16. Hystricurus millardensis Hintze (p. 31).

Figures 10-16 from loc. H-2.

10. Pygidium, USNM 186613, $\times 7.0$.

11-13. Cranidium, USNM 186614, $\times$ 4.2, anterior, lateral, and dorsal views.

14. Librigena USNM $186615, \times 5.8$.

15, 16. Cranidium, USNM 186616, $\times 4.5$, anterior and dorsal views. 
GEOLOGICAL SURVEY
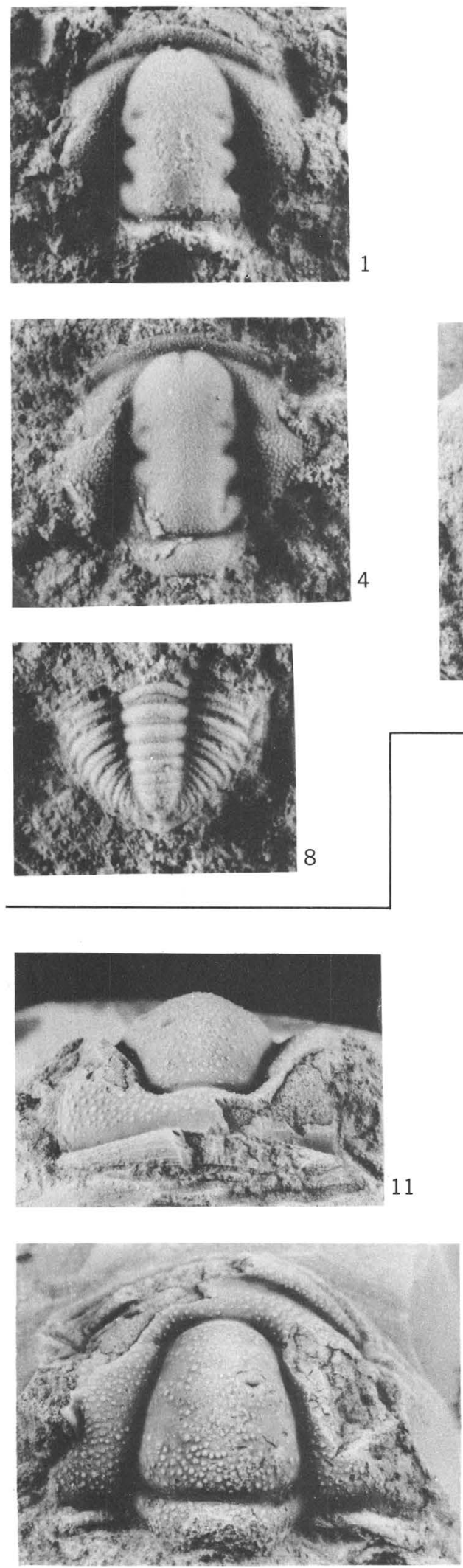

13
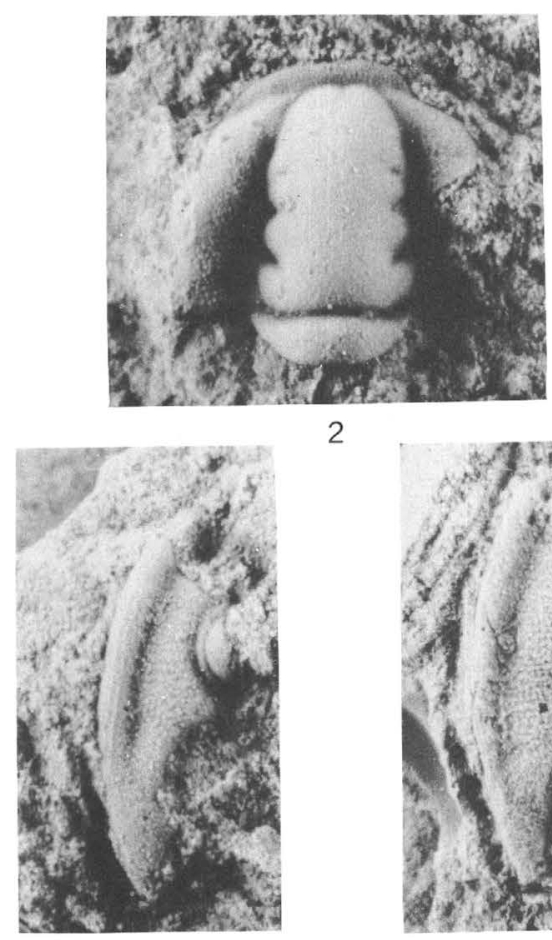

5

2

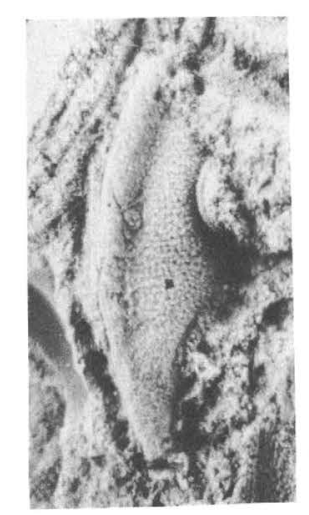

6
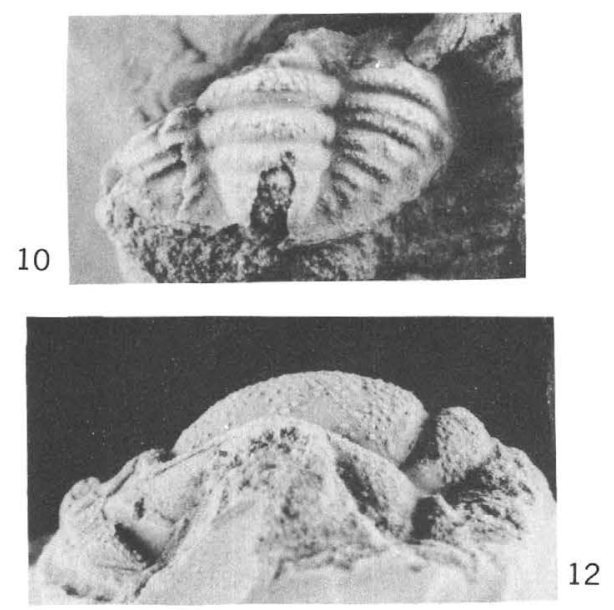

12

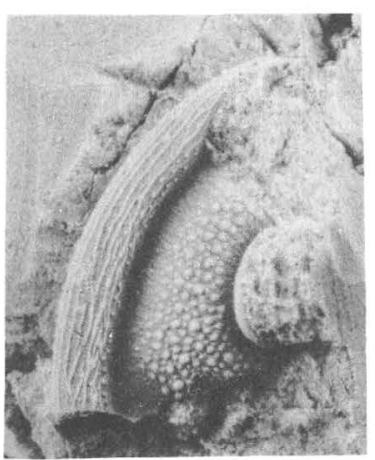

14
PROFESSIONAL PAPER 834 PLATE 3

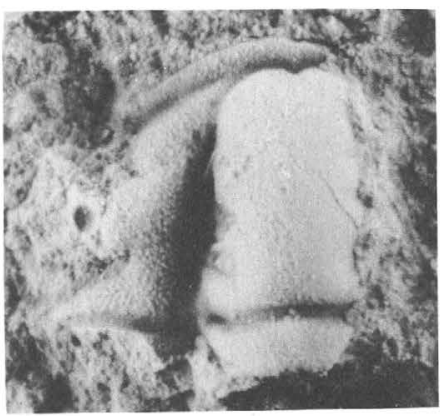

3
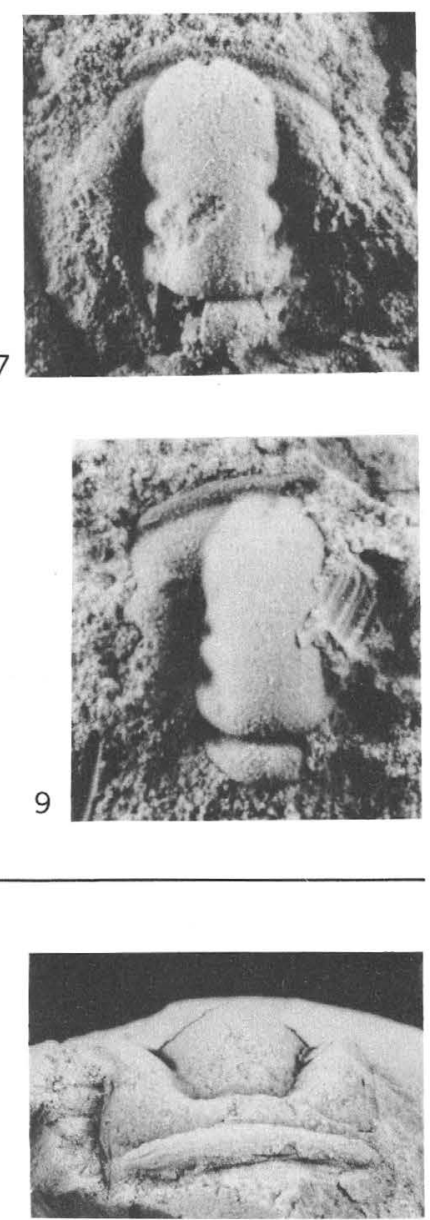

15

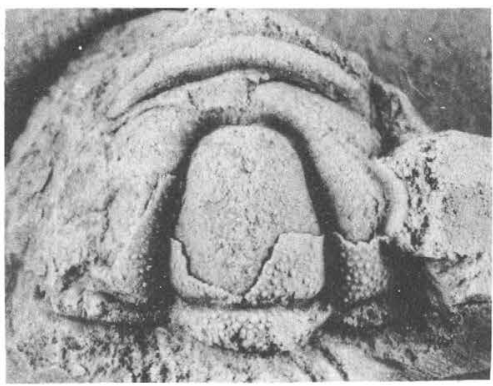

16 


\section{PLATE 4}

[Bar is $0.5 \mathrm{~mm}$ long, except fig. 3 in which bar is $0.13 \mathrm{~mm}$ long. All photomicrographs taken in plane-polarized light unless indicated otherwise]

FigURES

1-6. Lower Whitehall Formation, Crossman quarry.

1. Oolitic grainstone composed of ooids, oolitically coated pellets, and skeletal fragments.

2. Pelletal and lithoclastic grainstone containing minor amounts of quartz sand.

3. Length-slow chalcedony from along the fenestral wall of a thrombolite, crossed polarizers.

4. Thrombolite fenestra partly filled with internal pelleted sediment.

5. Border between light and dark clots of thrombolite having a clastic internal texture. Spar-rich area (left) does not appear grain supported, and is dark gray in hand specimen. Area of closely packed pellets (right) appears light gray in hand specimen.

6. Stromatolite laminations produced by variations in grain size.

7. Echinoderm fragments characterized by serrate edges, single-crystal extinction, and syntaxial cement, Hoyt Limestone, Lester Park, Saratoga County, N.Y.

8. Oblique section through fragment of dasycladacean alga, USNM 186617, Hoyt Limestone, Lester Park, Saratoga County, N.Y. Dasyclads from the Hoyt were identified by John L. Wray (written commun. to Halley, 1970). 
GEOLOGICAL SURVEY
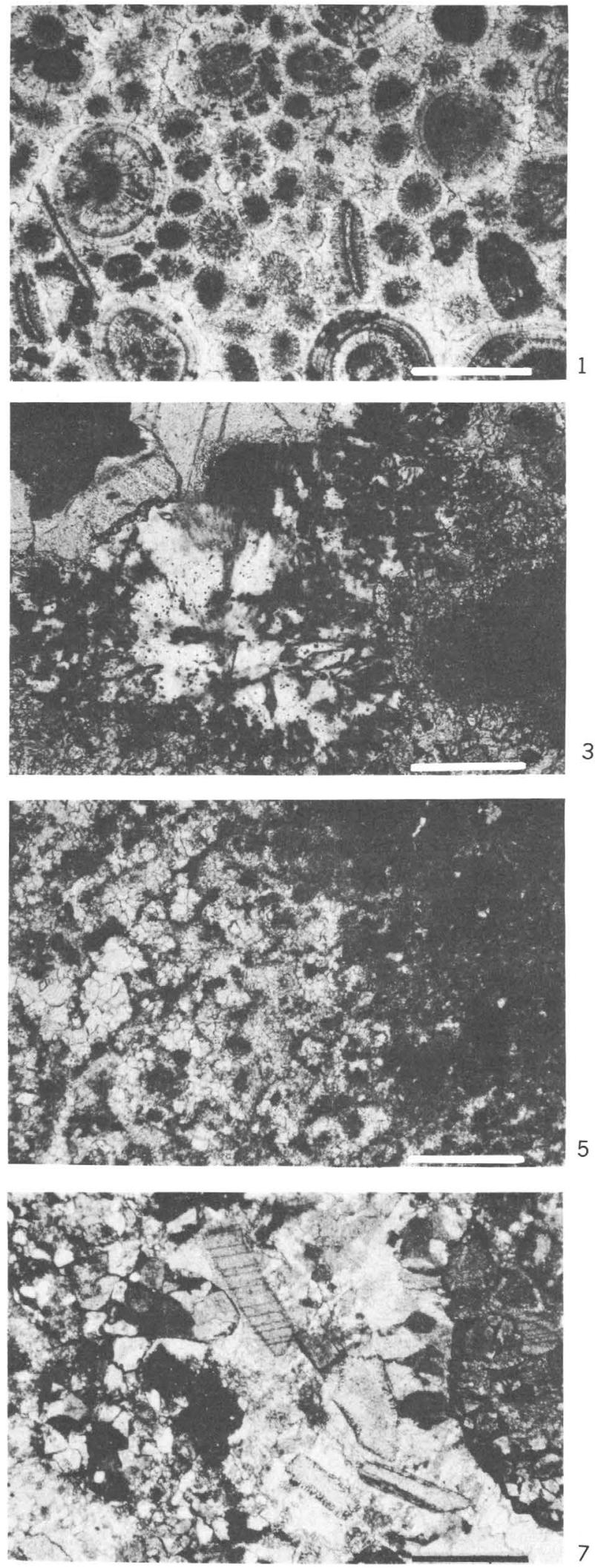

PROFESSIONAL. PAPER 834 PLATE 4
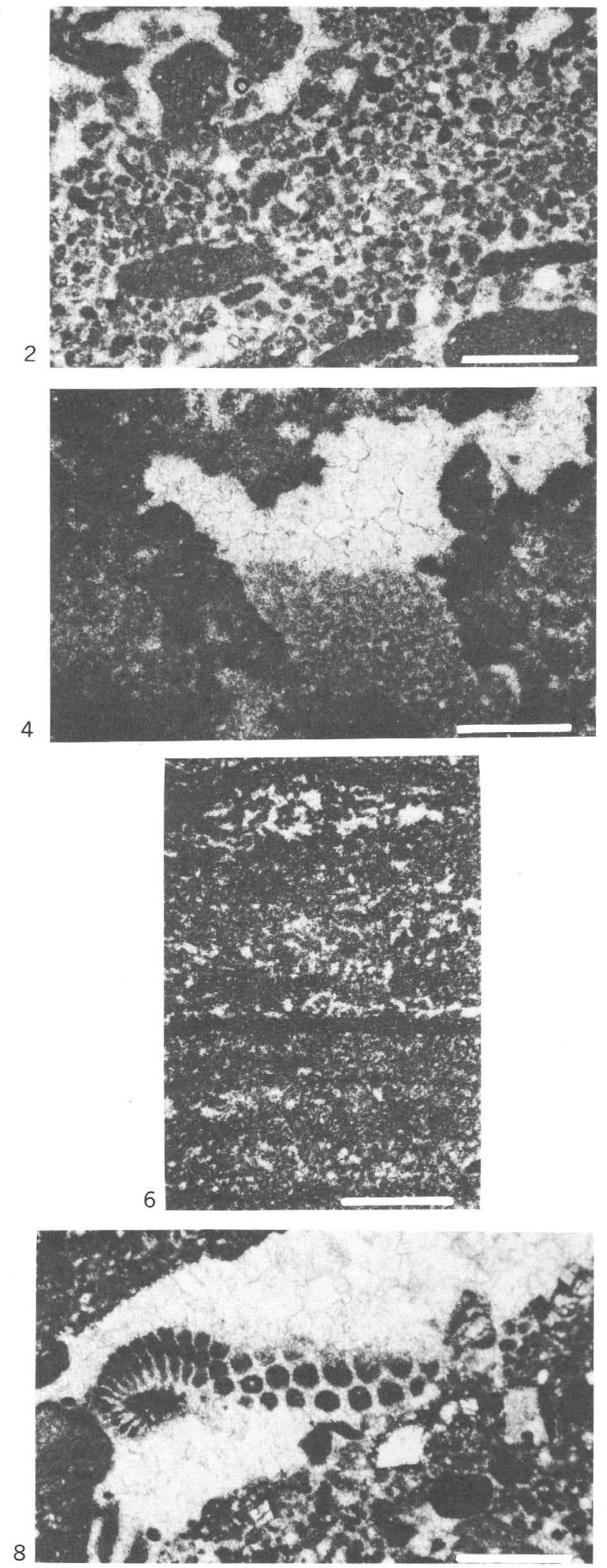
